\title{
Lower and Middle Cenomanian ammonites from the Morondava Basin, Madagascar
}

\author{
WILLIAM JAMES KENNEDY' ${ }^{1}$, IRENEUSZ WALASZCZYK², ANDREW S. GALE³, \\ KRZYSZTOF DEMBICZ ${ }^{4}$ AND TOMASZ PRASZKIER ${ }^{4}$ \\ ${ }^{1}$ Oxford University Museum of Natural History, Parks Road, Oxford OX1 3W and Department of Earth Sciences, \\ Parks Road, Oxford OX13AN, United Kingdom.E-mail: jim.kennedy@oum.ox.ac.uk \\ ${ }^{2}$ Faculty of Geology, University of Warsaw, Al. Żwirki i Wigury 93, PL-02-089 Warszawa, Poland \\ ${ }^{3}$ Department of Earth and Environmental Sciences, University of Portsmouth, Portsmouth PO1 3QL. \\ United Kingdom \\ ${ }^{4}$ Spirifer Geological Society, Warszawa, Poland
}

\begin{abstract}
:
Kennedy, W.J., Walaszczyk, I., Gale, A.S., Dembicz, K. and Praszkier, T. 2013. Lower and Midle Cenomanian ammonites from the Morondava Basin, Madagascar. Acta Geologica Polonica, 63 (4), 625-655. Warszawa.

Lower and Middle Cenomanian ammonite assemblages have been collected on a bed-by-bed basis from localities at Vohipaly and Mahaboboka, Madagascar, as well as from outcrops around Berekata, all in the Morondava Basin, southwest Madagascar. These collections demonstrate the presence of the upper Lower Cenomanian Mantelliceras dixoni Zone and the lower Middle Cenomanian Cunningtoniceras inerme Zone of the north-western European standard sequence. These records indicate that the striking anomalies in the zonal assemblages of the classic divisions of the Madagascan Cenomanian are based on mixed assemblages, rather than a succession that differs radically from that elsewhere in the world. The dixoni Zone fauna is: Desmoceras cf. latidorsatum (Michelin, 1838), Pachydesmoceras kossmati Matsumoto, 1987, Forbesiceras sp., F. baylissi Wright \& Kennedy, 1984, F. largilliertianum (d'Orbigny, 1841), Mantelliceras cantianum Spath, 1926a, M. dixoni Spath, 1926b, M. mantelli (J. Sowerby, 1814), M. picteti Hyatt, 1903, M. saxbii (Sharpe, 1857), Sharpeiceras sp., S. falloti (Collignon, 1931), S. mocambiquense (Choffat, 1903), S. cf. florencae Spath, 1925, Acompsoceras renevieri (Sharpe, 1857), A. tenue Collignon, 1964, Calycoceras sp., Mrhiliceras lapparenti (Pervinquière, 1907), Mariella (Mariella) stolizcai (Collignon, 1964), Hypoturrilites taxyfabreae (Collignon, 1964), Turrilites scheuchzerianus Bosc, 1801, Sciponoceras cucullatum Collignon, 1964, and Sciponoceras antanimangaensis (Collignon, 1964). The presence of Calycoceras in a Lower Cenomanian association represents a precocious appearance of a genus typically Middle and Upper Cenomanian in occurrence, and matches records from Tunisia. The inerme Zone yields a more restricted assemblage: Pachydesmoceras kossmati, Forbesiceras baylissi, Acanthoceras sp. juv., Cunningtoniceras cunningtoni (Sharpe, 1855) and Hypoturrilites taxyfabreae.
\end{abstract}

Key words: Madagascar; Morondava Basin; Cenomanian; Ammonite succession; Ammonite zonation; Chronostratigraphy.

\section{INTRODUCTION}

Since the publications of Besairie and Collignon (1960) and Collignon (1964), the Cenomanian ammonite succession in Madagascar has remained enig- matic; if true it would be the only place where the sequence of ammonite assemblages is different from that anywhere else in the world. To confirm or disprove this, new, precisely located material was needed. 
Bed-by-bed collecting from a number of Cenomanian successions was carried out during the 20052007 field expeditions to Madagascar to re-study the Upper Cretaceous successions and stratigraphy of the Morondava Basin, sponsored by the Polish Ministry of Science and Education (see Walaszczyk et al. 2014). Cenomanian successions were examined at Mahaboboka, Vohipaly and Bereketa, three localities east of the town of Tulear in the southern part of the Basin (Text-fig. 1), covering part of the classic sections studied originally by Collignon and Besairie. Although the lowermost part of the Cenomanian is missing, much of the Lower and lower part of the Middle Cenomanian is represented in the sections studied. The sequences are very fossiliferous, with good preservation of the material. For regional details see the general report on the Upper Cretaceous of the Morondava Basin published recently by Walaszczyk et al. (2014).

\section{LOCALITY DETAILS}

The three localities studied, spanning the upper Lower to lower Middle Cenomanian, are located near and south of the town of Mahaboboka, in the southern part of the Morondava Basin (Text-fig. 1; see also Walaszczyk et al. 2014). All three are easily accessi- ble with relatively good correlation between the sections (Text-fig. 2).

The Mahaboboka section: This section is located west of the town of Mahaboboka, on the northern side of the Route National no 7 leading to Tulear, SW of the bridge in the western margin of the town. The Cenomanian part of the sequence is well exposed and easily accessible in the trench beside the road and in the middle and upper parts of the $420 \mathrm{~m}$ high hill with a tomb north of the road. Four distinctive units (M1 through to M4) of the Lower and Middle Cenomanian crop out in the trench (M1 and M2) and in the upper part of the $420 \mathrm{~m}$ hill (M3 and M4) (Text-fig. 2; see also Walaszczyk et al. 2014, fig. 2-3). M1 contains monospecific inoceramid assemblages of Inoceramus flavus Sornay, 1965. M2, which is lithologically similar to M1, contains numerous I. flavus and relatively common echinoids. Ammonites appear in unit M3, with Cunningtoniceras cunningtoni, marking the basal Middle Cenomanian. Both ammonites and inoceramids are common higher in the sequence, in unit M4.

The Vohipaly section: This section is located south of Mahaboboka, c. $1.5 \mathrm{~km}$ south-west of the Vohipaly Mountain, the highest point in the area (Text-fig. 1).
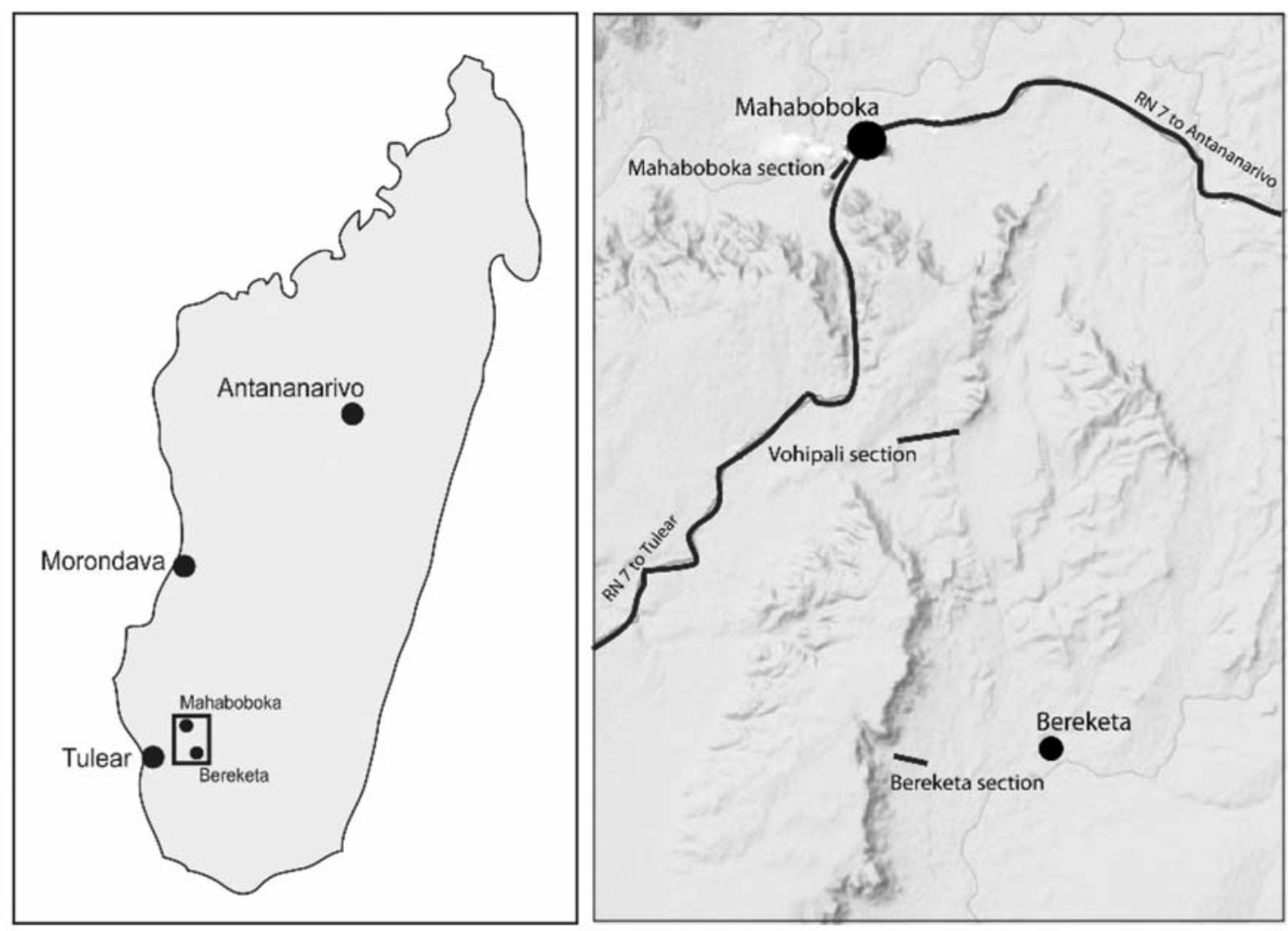

Text-fig. 1. Location of the Mahaboboka, Vohipaly and Bereketa sections 


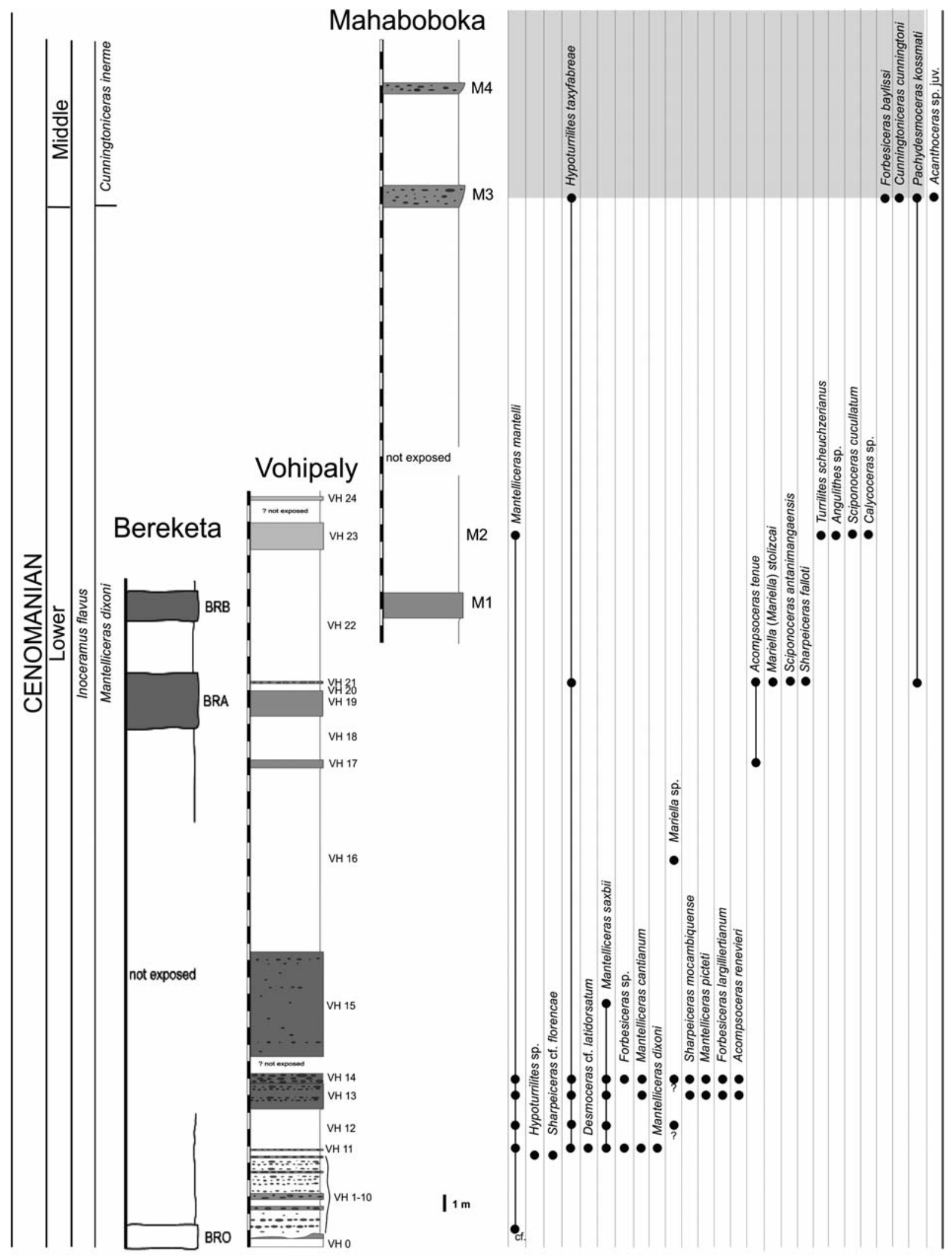

Text-fig. 2. Geological logs, chronostratigraphy, correlation and ammonite ranges in the Lower-Middle Cenomanian of the Mahaboboka, Vohipaly and Bereketa sections; for location see Text-fig. 1 (modified after Walaszczyk et al. 2014, fig. 3) 
The Cenomanian crops out on the slopes of the small hill and cuesta west of the small river that flows N-S, following the strike of the Cenomanian sequence. The strike of the beds run at approximately $20-30^{\circ}$ and they dip gently $\left(7-10^{\circ}\right)$ to the west. The quite expanded succession of Vohipaly does not range as high stratigraphically as the succession in Mahoboboka (Text-fig. 2) and is entirely within the upper Lower Cenomanian Mantelliceras dixoni Zone.

The Bereketa section: This section was constructed from three exposures west of the village of Bereketa, south of Vohipaly (Text-fig. 1). Three fossiliferous horizons are represented, the oldest in the east (Textfig. 2). The basal bed (BRO) is well-exposed close to the river flowing south-west of the village of Bereketa. It is a Lower Cretaceous (Valvanginian?) limestone with lithoclasts, brachiopods and ammonites, forming a distinct ledge in the field. Its thickness is unknown; however, Jurassic limestones crop out in the riverbed. BRO is capped by sandy siltstone and silty sandstone of the Cenomanian age (Text-fig. 2). Two fossiliferous horizons of poorly to moderately cemented brown-grey sandy siltstone were recognised in the Cenomanian. The older horizon (BRA), exposed c. 500 $\mathrm{m}$ west of BRO, is estimated to be c. $40 \mathrm{~m}$ above BRO. The younger horizon (BRB), occurring c. $80 \mathrm{~m}$ westward of BRA, is estimated to lie c. $6 \mathrm{~m}$ above BRA. BRA is c. $4 \mathrm{~m}$ thick and contains numerous ammonites and inoceramids. BRB, c. 2 m thick bed, contains numerous poorly cemented concretions with well preserved ammonites, echinoids and inoceramids. Both BRA and BRB are referred to the upper Lower Cenomanian Mantelliceras dixoni Zone.The correlation with the Vohipaly and Mahaboboka sections is shown in Text-fig. 2.

\section{AGE OF THE FAUNAS}

The Cenomanian ammonite zonations recognised in Madagascar by Besairie and Collignon (1960) and Collignon (1964) are shown in Table 1. As pointed out more than 40 years ago (Kennedy 1971, p. 116), these zones are either based on mixed assemblages from particular localities, or the sequence of Cenomanian ammonite faunas of Madagascar is different from that elsewhere in the world. Thus Mantelliceras martimpreyi (Coquand, 1862) is a junior synonym of Mantelliceras saxbii (Sharpe, 1857). The Madagascan martimpreyi Zone fauna as described by Collignon (1964) is one of limonitic nuclei of species that also occur as large individuals in the coarser terrigenous-clastic facies that yielded the mantellli-newboldi Zone fauna described in the same work, including key stratigraphic indicators such as Neostlingoceras carcitanense (Matheron, 1842). Collignon's martimpreyi Zone fauna also includes adults of genuinely diminutive taxa such as Neosaynoceras Breistroffer, 1947, and Flickia Pervinquière, 1907, not found in the coarser terrigenous-clastic facies as a result, presumably, of either contemporaneous environmental factors or postmortem processes. The mantelli-newboldi Zone faunas in Collignon (1964) include species that are characteristic of the Lower Cenomanian (Neostlingoceras carcitanense, Mantelliceras dixoni Spath, 1926b), Middle Cenomanian (Turrilites costatus Lamarck, 1801, Turrilites acutus Passy, 1832), and Upper Cenomanian (Eucalycoceras pentagonum (Jukes-Browne, 1896). The Euomphaloceras euomphalum of Collignon, 1964 (p. 146) is a Cunningtoniceras cunningtoni (Sharpe, 1855), while undoubted Upper Cenomanian Euomphaloceras euomphalum (Sharpe, 1855) (=Metasigaloceras trituberculatum Collignon, 1964)

\begin{tabular}{|c|c|c|}
\hline SUBSTAGE & $\begin{array}{c}\text { ZONE } \\
\text { (Besairie \& Collingnon, 1960) }\end{array}$ & $\begin{array}{c}\text { ZONE } \\
\text { (Collignon, 1964) }\end{array}$ \\
\hline Upper Cenomanian & $\begin{array}{l}\text { Hourcqiceras sp. } \\
\text { Acanthoceras rhotomagense }\end{array}$ & Acanthoceras rhotomagense \\
\hline Middle Cenomanian & Euomphaloceras cunningtoni & Euomphaloceras euomphalum \\
\hline \multirow{2}{*}{ Lower Cenomanian } & $\begin{array}{l}\text { Mantelliceras mantelli et } \\
\text { Calycoceras newboldi }\end{array}$ & $\begin{array}{l}\text { Mantelliceras mantelli et } \\
\text { Calycoceras newboldi }\end{array}$ \\
\hline & Mantelliceras martimpreyi & Mantelliceras martimpreyi \\
\hline
\end{tabular}

Table 1. Ammonite zonation of the Cenomanian of Madagascar according to Besairie and Collignon (1960) and Collignon (1964) 
CENOMANIAN AMMONITES FROM MADAGASCAR

\begin{tabular}{|c|c|c|}
\hline SUBSTAGE & ZONE & SUBZONE \\
\hline Upper Cenomanian & $\begin{array}{l}\text { Neocardioceras juddii } \\
\text { Metoicoceras geslinianum } \\
\text { Calycoceras guerangeri }\end{array}$ & \\
\hline Middle Cenomanian & $\begin{array}{l}\text { Acanthoceras jukesbrownei } \\
\\
\text { Acanthoceras rhotomagense }\end{array}$ & $\begin{array}{l}\text { Turrilites acutus } \\
\text { Turrilites costatus }\end{array}$ \\
\hline & Cunningtoniceras inerme & \\
\hline Lower Cenomanian & $\begin{array}{l}\text { Mantelliceras dixoni } \\
\\
\text { Mantelliceras mantelli }\end{array}$ & $\begin{array}{l}\text { Mantelliceras saxbii } \\
\text { Sharpeiceras schlueteri } \\
\text { Neostlingoceras carcitanense }\end{array}$ \\
\hline
\end{tabular}

Table 2. Standard Cenomanian ammonite Zones for the north-west European sequence

occur in the zone. The Acanthoceras rhotomagense of Collignon (1964) belongs neither to that genus or species. In the context of the present material, the standard north-western European scheme set out in Table 2 provides a sounder basis for discussion.

The Vohipaly section is entirely Lower Cenomanian. Absence of Neostlingoceras carcitanense (Matheron, 1842) and N. oberlini (Dubourdieu, 1953), recorded elsewhere in Madagascar, suggest a horizon above the base of the stage for the base of the succession. The sparse fauna of beds 2 and 10 (Mantelliceras cf. mantelli (J. Sowerby, 1814), Sharpeiceras cf. florencae Spath, 1925, Hypoturrilites sp.) can only be dated as Lower Cenomanian. The appearance of Mantelliceras dixoni Spath, 1926b, in bed 11 (Pl. 4, Figs 1, 2) indicates the upper Lower Cenomanian Mantelliceras dixoni Zone (Table 2). Levels up to bed 23 are also referred to the dixoni Zone on the basis of the continuing presence of Mantelliceras, and this is supported by the occurrence of Acompsoceras renevieri (Sharpe, 1857) (P1. 8, Figs 7,8 ), from beds 13-14, and the appearance of Turrilites scheuchzerianus Bosc, 1801 (P1. 9, Figs 1-3), in bed 23; the first appearance of which is in association with Mantel- liceras species in the dixoni Zone in Europe. The presence of Calycoceras in bed 23 (UW 1292; Pl. 1, Figs 1-3) is remarkable, as the genus does not appear until the Middle Cenomanian in Europe. However, limonitic nuclei of a closely similar species of Calycoceras are present in the Lower Cenomanian of Tunisia (Robaszynski et al. 1994).

The full Vohipaly dixoni Zone fauna is: Desmoceras cf. latidorsatum (Michelin, 1838), Pachydesmoceras kossmati Matsumoto, 1987, Forbesiceras sp., F. baylissi (Wright and Kennedy, 1984), F. largilliertianum (d'Orbigny, 1841), Mantelliceras cantianum (Spath, 1926a), M. dixoni Spath, 1926b, M. mantelli (J. Sowerby, 1814), M. picteti Hyatt, 1903, M. saxbii (Sharpe, 1857), Sharpeiceras sp., S. falloti (Collignon, 1931), S. mocambiquense (Choffat, 1903), S. cf. florencae Spath, 1925, Acompsoceras renevieri (Sharpe, 1857), A. tenue Collignon, 1964, Calycoceras sp., Mrhiliceras lapparenti (Pervinquière, 1907), Mariella (Mariella) stolizckai (Collignon, 1964), Hypoturrilites taxyfabreae (Collignon, 1964), Turrilites scheuchzerianus Bosc, 1801, Sciponoceras cucullatum Collignon, 1964, and Sciponoceras antanimangaensis (Collignon, 1964). 
The assemblages from the outcrops around Berekata (BRA, BRO, and BRB) include several species that are present in the dixoni Zone of the Vohipaly section, and these are tentatively assigned to this Zone. The full faunal list from these localities is: Forbesiceras baylissi Wright and Kennedy, 1984, Mantelliceras sp., M. mantelli (J. Sowerby, 1814), M. saxbii (Sharpe, 1857), Sharpeiceras sp., Acompsoceras tenue (Collignon, 1964), Acompsoceras sp., Mariella sp., Mariella stolizcai (Collignon, 1964), Hypoturrilites sp., Sciponoceras sp., and Sciponoceras antanimangaensis (Collignon, 1964).

There are no identifiable ammonites from the lower part (beds M1 and M2) of the Mahaboboka section, but the presence of Cunningtoniceras cunningtoni (Sharpe, 1855) in bed M3 (P1. 8, Figs 1-6)) indicates the basal Middle Cenomanian Cunningtoniceras inerme Zone of the northwestern European sequence. Bed M3 also yielded Pachydesmoceras kossmati, Forbesiceras baylissi, Acanthoceras sp. juv, and Hypoturrilites taxyfabreae.

In conclusion it is clear that the detailed bed-bybed collections described below demonstrate the presence of faunas characteristic of the upper Lower Cenomanian Mantelliceras dixoni Zone and the lower Middle Cenomanian Cunningtoniceras inerme Zone of the north-west European standard sequence in the Morondava Basin. The Madagascan Cenomanian faunas described by Collignon (1964) include either zonal/subzonal indices or key marker species of the Neostlingoceras carcitanense, Sharpeiceras schlueteri, and Mantelliceras saxbii subzones of the Mantelliceras mantelli Zone, the Cunningtoniceras inerme Zone, theTurrilites acutus and Turrilites acutus subzones of the Acanthoceras rhotomagense Zone, the Acanthoceras jukesbrownei Zone and the Calycoceras guerangeri Zone (Table 2). Confirmation of the sequence of faunas in the field is for the future.

\section{CONVENTIONS}

BMNH: The Natural History Museum, London.

MNHP: The Laboratoire de Paléontologie of the Muséum National d'Histoire Naturelle, Paris.

FGUW: Collections of the Faculty of Geology, University of Warsaw.

All dimensions are given in millimetres. The suture terminology is that of Korn et al. (2003): E = external lobe; $\mathrm{A}=$ adventive lobe (= lateral lobe, L, of Kullmann and Wiedmann 1970); U = umbilical lobe; I = internal lobe.
SYSTEMATIC PALAEONTOLOGY (W.J. Kennedy)

\author{
Superfamily Desmoceratoidea Zittel, 1895 \\ Family Puzosiinae Spath, 1922 \\ Subfamily Puzosiinae Spath, 1922 \\ Genus Pachydesmoceras Spath, 1922
}

TYPE SPECIES: Ammonites denisonianus Stoliczka, 1865 , p. 153 , pl. $66 \mathrm{a}$, by the original designation of Spath 1922, p. 127.

Pachydesmoceras kossmati (Matsumoto, 1987)

(P1. 1, Fig. 6; Text-fig. 3)

1865. Ammonites denisonianus Stoliczka, p. 153 (pars), pl. 66, fig. 2.

1898. Desmoceras (Puzosia) Denisoniana Stoliczka sp.; Kossmat, p. 121 (186), pl. 14 (21), fig. 6, pl. 15 (21), fig. 5.

1922. Pachydesmoceras denisonianum (Stoliczka); Spath, p. 127.

1987. Pachydesmoceras kossmati Matsumoto, p. 6, text-fig. 1.

1988. Pachdyesmoceras kossmati Matsumoto; Matsumoto et al., in Matsumoto 1988 p. 116, text-figs 50-54.

TYPE: The holotype, by original designation of Matsumoto 1987, p. 6, is the original of Desmoceras (Puzosia) Denisoniana Stoliczka sp. of Kossmat 1898, p. 121 (186), pl. 14 (21), fig. 6, pl. 15 (21), fig. 5, a specimen in the collections of the Geological Survey of India, from the brown calcareous concretions in the Utatur Group of Odium, Tamil Nadu, south India. It is imprecisely dated in the Cenomanian-Turonian interval. There are a number of paratypes, as listed by Matsumoto (1987) and Matsumoto et al. in Matsumoto (1988)

MATERIAL: UW1248, inferred to be from bed 21 of the Vohipaly section. UW1900, from bed M3 of the Mahaboboka section.

DESCRIPTION: UW1900 (P1. 1, Fig. 6) preserves part of one flank only, with traces of the aragonitic shell, of a specimen with an estimated original diameter of 75 $\mathrm{mm}$, with a $290^{\circ}$ sector of body chamber. Coiling appears to have been moderately evolute, the umbilicus of moderate depth, with a vertical, feebly convex umbilical wall and rounded umbilical shoulder. The flanks are very feebly convex, converging to broadly rounded ventrolateral shoulders. An estimated 24-26 primary ribs per whorl arise on the umbilical shoulder or innermost flank. They are feebly convex across the um- 
bilical shoulder, strengthen progressively across the inner and middle flank, where they are straight and prorsiradiate, then flexing forwards and concave on the outer flank, where they bifurcate and additional ribs intercalate so that there are many more ribs on the ventrolateral shoulders than at the umbilical shoulder. The ribs are initially straight on the ventrolateral shoulders before flexing forwards, indicating that they crossed the venter in a convex peak. Five of the primary ribs on the adapertural half whorl of the fragment are strengthened into collar ribs that flank a succeeding constriction. UW1248 (Text-fig. 3) is a $120^{\circ}$ whorl sector of phragmocone with extensive areas of original shell material preserved. The maximum preserved whorl height is 88 $\mathrm{mm}$; the whorl breadth to height ratio is 0.93 . The innermost part of the umbilical wall of the succeeding whorl is preserved. The umbilical wall is feebly convex,

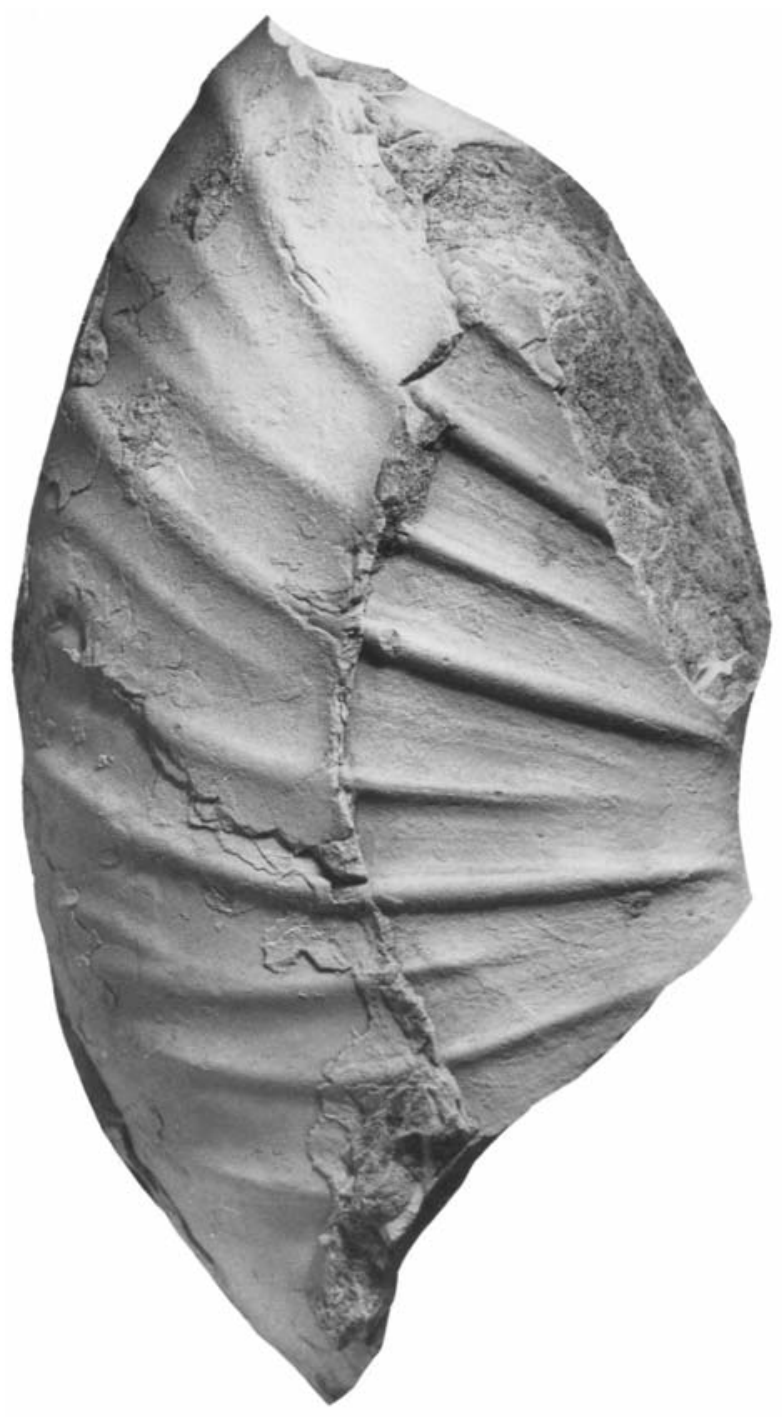

the umbilical shoulder broadly rounded, the inner to mid-flank region feebly convex and subparallel.

Six primary ribs are preserved on the flank illustrated. The ribs arise on the umbilical shoulder and strengthen at varying rates, reaching their full development on either the umbilical shoulder or inner flank. They are strong, narrow, straight and prorsiradiate on the inner and middle flank, and are separated by very wide interspaces. The ribs flex forwards on the outer flank and are very feebly concave. Some, but not all of the primary ribs bifurcate on the outermost flank/ventrolateral shoulder, while additional ribs intercalate, to give a total of fourteen ribs at the ventrolateral shoulder in the sector with the six primaries. The ribs sweep forwards and are markedly convex across the venter, the secondary and intercalated ribs strengthening to match the primaries.

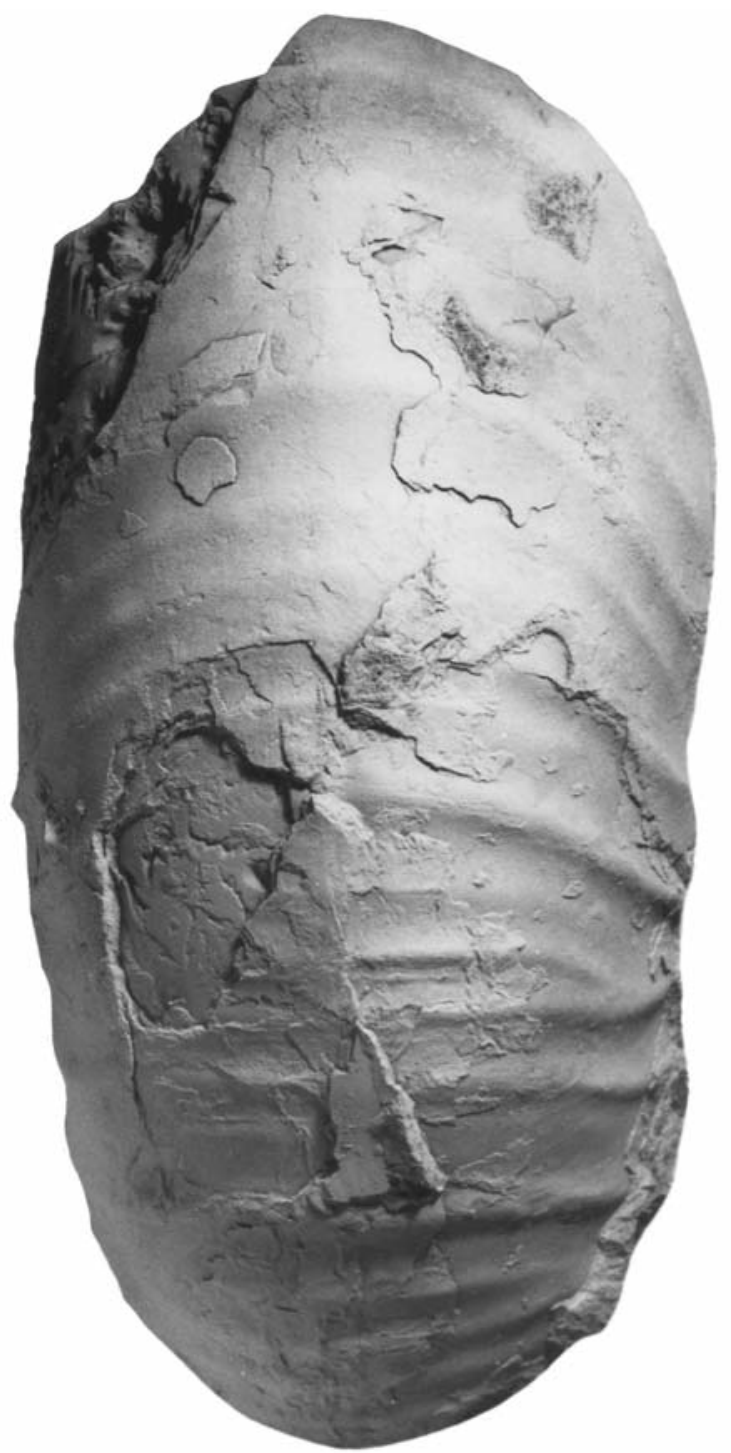


DISCUSSION: The larger fragment is referred to Pachydesmoceras kossmati on the basis of similarities to the holotype and specimens of comparable size figured by Stoliczka (1865, pl. 66, fig. 2) and Matsumoto et al. (in Matsumoto 1988, p. 116, text-figs 50-54). In particular, the pattern of alternating primary ribs that occasionally bifurcate and the single intercalated ribs of the holotype are identical. Our smaller specimen with crowded ribs that flex strongly forwards on the outer flank and ventrolateral shoulder match those of the holotype, although the latter shows fewer bifurcations. The lectotype of Pachydesmoceras denisonianum (Stoliczka, 1865, p. 153, fig. 66a) is a huge specimen, over $1000 \mathrm{~mm}$ in diameter, and from the Utatur Group northeast of Odium, Tamil Nadu, south India. Its early growth stages are unknown, and it was differentiated from kossmati on the basis of the higher expansion rate, more frequent and persistent primary ribs that project forwards on the outer flank and ventrolateral shoulder, and the presence of primary ribs only on much of the adult body chamber of the macroconch holotype. See Matsumoto et al. (in Matsumoto, 1988) for further discussion.

OCCURRENCE: Lower and Middle Cenomanian of Madagascar, Cenomanian or Turonian of south India, Lower and Middle Turonian of Japan.

Family Desmoceratidae Zittel, 1895

Subfamily Desmoceratinae Zittel, 1895

Genus and Subgenus Desmoceras Zittel, 1884

TYPE SPECIES: Ammonites latidorsatus Michelin, 1838 , p. 101, pl. 12 , fig. 9 , by the subsequent designation of Böhm 1895, p. 364.

\section{Desmoceras (Desmoceras) cf. latidorsatum (Michelin, 1838)}

Compare:

1838. Ammonites latidorsatus Michelin, p. 101, pl. 12, fig. 9. 1968. Desmoceras (Desmoceras) latidorsatum (Michelin, 1838); Wiedmann and Dieni, p. 131, pl. 2, figs 2, 613, text-fig. 81 (with synonymy).

1990. Desmoceras (Desmoceras) latidorsatum (Michelin, 1838); Marcinowski and Wiedmann, p. 62, pl. 7, figs 2, 3 (with synonymy).

2007. Desmoceras (Desmoceras) latidorsatum (Michelin, 1838); Kennedy and Latil, p. 458, pl. 2, fig. 1; pl. 6, figs 2, 3; text-fig. 4 .

2007. Desmoceras (Desmoceras) latidorsatum (Michelin,
1838); Szives, p. 98, pl. 3, fig. 25; pl. 14, fig. 10; pl. 19, figs 3 , 4; pl. 26, figs 1, 2; pl. 28, fig. 6 .

2009. Desmoceras (Desmoceras) latidorsatum (Michelin, 1838); Kennedy and Bilotte, p. 46, pl. 2, figs 6, 7, 19-28; pl. 8, figs 21-23; text-fig. 4.

2011. Desmoceras latidorsatum (Michelin, 1838); Kennedy in Gale et al., p. 75.

MATERIAL: UW1293, from bed 11 of the Vohipaly section.

DESCRIPTION AND DISCUSSION: The specimen is a fragment only of a worn $120^{\circ}$ sector of the internal mould of a phragmocone with a whorl height of 31 $\mathrm{mm}$ at the adapical end. The whorl section is depressed reniform, with the greatest breadth at the umbilical shoulder, the whorl breadth to height ratio is an estimated 1.13 . The poorly preserved suture has a broad bifid E/A and narrow bifid A/U2. Poor as the fragment is, the overall morphology suggests the variable Desmoceras (D.) latidorsatum, comparing well with previously described Lower Cenomanian specimens from Madagascar, for example Collignon 1961, pl. 24, fig. 1 .

OCCURRENCE: Middle Albian to Upper Cenomanian, southern England, southern France, northern Spain, southern Germany, Switzerland, Hungary, Serbia, Poland, Sardinia, Crimea, Mozambique, Angola, KwaZulu-Natal South Africa, Madagascar, south India, Japan, Mexico and Venezuela.

Superfamily Acanthoceratoidea De Grossouvre, 1894 Family Forbesiceratidae Wright, 1952 Genus Forbesiceras Kossmat, 1897

TYPE SPECIES: By the subsequent designation of Diener 1925, p. 180: Ammonites largilliertianus D’Orbigny, 1841, p. 320, pl. 95.

\section{Forbesiceras largilliertianum (D’Orbigny, 1841)}

$$
\text { (P1. 1, Figs 10, 11) }
$$

1841. Ammonites Largilliertianus d'Orbigny, p. 320, pl. 95. 1984. Forbesiceras largilliertianum (d'Orbigny, 1841); Wright and Kennedy, p. 89, pl. 11, figs 2-6; pl. 12, figs $1-3,9$; pl. 16, fig. 2; text-figs $12 \mathrm{a}-1,13 \mathrm{a}-\mathrm{z}, 14 \mathrm{a}-\mathrm{h}$ (with full synonymy).

2006. Forbesiceras largilliertianum (d'Orbigny, 1841); Kennedy et al., in Gauthier, p. 116, pl. 54, figs 1-3. 2008. Forbesiceras largilliertianum (d'Orbigny, 1841); 
Kennedy and Klinger, p. 120, pl. 1, figs 2-5; text-figs 2a, f (pars), d, e.

LECTOTYPE: MNHP B46129 (d'Orbigny Collection 6120 A-1) figured by Wright and Kennedy 1984, text-fig. 12d, e, and Kennedy et al. in Gauthier 2006, pl. 54, fig. 1, from the Middle Cenomanian Rouen Fossil Bed of Côte Ste Catherine, Rouen, Seine-Maritime, France.

MATERIAL: UW1520, from beds $14-15$ of the Vohipaly section.

DESCRIPTION: The specimen is an internal mould of a phragmocone with a maximum preserved diameter of $91 \mathrm{~mm}$. Coiling is very involute, the umbilicus tiny. The whorls are very compressed, with a whorl breadth to height ratio of 0.36 , the greatest breadth below midflank, the flanks feebly convex, converging to sharp ventrolateral shoulders and a very narrow, feebly convex venter. Ornament is well-preserved and distinct to a diameter of around $80 \mathrm{~mm}$, beyond which it effaces. The ribs are delicate, weak, narrow, and crowded. Mere lirae on the innermost flank, they are straight and prorsiradiate, flexing back and very feebly convex across the middle of the flanks and very feebly concave on the outer flank. They strengthen progressively across the flanks, and increase by branching at midflank and on the outer flank; additional ribs may intercalate. All ribs link to minute oblique clavi adjacent to the sharp ventrolateral shoulder, the clavi connected across the venter by a transverse rib, although the venter is worn. The suture is deeply and intricately incised, with E/A divided by a deep adventive lobe, the terminal elements of the saddles phylloid.

DISCUSSION: Forbesiceras largilliertianum is distinguished from $F$. baylissi in the present collection on the basis of the presence of periodically strengthened ribs on the inner flanks and the much coarser outer flank ornament of the latter (compare Pl. 1, Figs 10, 11 and Pl. Figs 4, 5, 7-9).

OCCURRENCE: Forbesiceras largilliertianum ranges throughout the Lower and Middle Cenomanian. The geographic distribution extends from southern England to France, Switzerland, northern Spain, Algeria, Tunisia, KwaZulu-Natal in South Africa, Madagascar, South India, and Japan.

Forbesiceras baylissi Wright and Kennedy, 1984

(P1. 1, Figs 4, 5, 7-9)
1984. Forbesiceras baylissi Wright and Kennedy, p. 92, pl. 13 , figs 4,5 .

1984. Forbesiceras cf. baylissi Wright and Kennedy, p. 93, pl. 13, figs 3 .

1987. Forbesiceras baylissi Wright and Kennedy; Wright and Kennedy, p. 398, pl. 120, figs 7, 8.

?1998. Forbesiceras cf. baylissi Wright and Kennedy; Kaplan et al., p. 114 p. 11, fig. 4.

2011. Forbesiceras baylissi Wright and Kennedy; Mosavina and Wilmsen, p. 178, text-fig. $3 \mathrm{f}$.

TYPE: The holotype is BMNH C83698, the paratype is BMNH C83699, both from the lower Cenomanian Mantelliceras dixoni Zone fauna of bed B of the Cenomanian Limestone at Shapwick Grange, Devon, and figured by Wright and Kennedy, 1984, p. 92, pl. 13, figs 4,5 .

MATERIAL: UW1820 from bed M3 of the Mahabobka section. UW1262 and 1496, from the Bereketa section.

DESCRIPTION: UW1820 and 1496 are juveniles 45 and $53 \mathrm{~mm}$ in diameter respectively. Coiling is very involute, the umbilicus minute. The whorl section is very compressed, with a whorl breadth to height ratio of 0.4 , the feebly convex flanks subparallel, with the greatest breadth around mid-flank. The ventrolateral shoulders are sharp, the venter narrow, flat, with shallow grooves between lateral and median ridges, producing a bluntly tricarinate venter. UW1496 (Pl. 1, Figs 7,8$)$ is a finer-ribbed variant, and UW1820 a coarser ribbed variant, both showing the same basic style of ornament. Sharp, narrow, quite widely separated stronger primary ribs are straight to feebly concave and markedly prorsiradiate on the inner flank. They bi-or trifurcate around mid-flank, the secondary ribs concave and strengthening markedly across the outer flank, and becoming relatively coarse on the outermost flank. These stronger primaries are separated by one or more much weaker primary and long intercalated ribs that strengthen to match the other primaries on the outer flank. All ribs link to small, sharp clavi, perched on the sharp ventrolateral shoulder. The clavi are linked across the venter by a low, blunt transverse rib, strengthened into a tiny feeble siphonal tubercle in UW1496 (Pl. 1, Fig. 8). UW1262 (Pl. 1, Fig. 9) is septate to $70 \mathrm{~mm}$ diameter approximately, and preserved to a maximum diameter of 83 $\mathrm{mm}$. It is embedded in matrix, with only one flank and the venter of the adapical half whorl visible. The style of ornament at the smallest diameters visible is as in the previous specimens. The differentiation of the stronger 
primary ribs on the inner flank is particularly well- developed up to a whorl height of $44 \mathrm{~mm}$. Beyond this, the inner flank ornament weakens, and the outer flank ribbing coarsens and broadens. The siphonal ridge, with small siphonal tubercles, is well-developed.

DISCUSSION: Differences between co-ocurring Forbesicersas baylissi and F. largilliertianum are noted above.

OCCURRENCE: Mantelliceras dixoni Zone of Devon, England, northern Iran, and Madagascar, and possibly the Münster Basin, Germany, ? lower Middle Cenomanian of Devon, England.

Family Acanthoceratidae De Grossouvre, 1894

Subfamily Mantelliceratinae Hyatt, 1903

Genus Mantelliceras Hyatt, 1903

TYPE SPECIES: By original designation: Ammonites mantelli J. Sowerby, 1814, p. 199 (ICZN Specific Name No. 1634).

Mantelliceras mantelli (J. Sowerby, 1814)

(Pl. 2, Figs 1-7; P1. 3, Figs 1-5)

1814. Ammonites mantelli J. Sowerby, p. 119, pl. 55, lower figure only.

1964. Mantelliceras mantelli J. Sow.; Collignon, p. 27, pl. 323, fig. 1436; p. 66, pl. 337, figs 1506-1508; p. 68, pl. 338, figs 1509, 1510 (var. percostata).

1964. Mantelliceras tuberculatum Mant.; Collignon, p. 27, pl. 323, fig. 1437; p. 68, pl. 338, fig. 1511 (var. umbilicata); p. 69, pl. 339, figs. 1513, 1514, 1515, 1516 (var. pinguis), 1517 (var. pinguis); p. 73, pl. 341, fig. 1527.

1964. Mantelliceras ampakabense Collignon, p. 74, pl. 341, fig. 1528.

1964. Mantelliceras isovokyense Collignon, p. 76, pl. 342, figs $1529,1530$.

1964. Mantelliceras betiokyense Collignon, p. 78, pl. 343, figs 1531, 1532.

1964. Mantelliceras alternans Collignon, p. 97, pl. 351, fig. 1557. 1984. Mantelliceras mantelli (J. Sowerby, 1814); Wright and Kennedy, p. 99, pl. 16, fig. 5; pl. 17, figs 1, 3; pl. 18, figs $1-3$; pl. 19, figs 1-6; pl. 21, figs 1, 2, 4; pl. 24, fig. 3; pl. 36, fig. 1; text-figs 20a-d, 26a, c, e, 28a-e (with full synonymy).

1998. Mantelliceras mantelli (J. Sowerby, 1814); Kaplan et al., p. 115, pl. 11, figs 1, 2; pl. 17, figs 12, 13; pl. 19, figs 19; pl. 22, figs 3, 4; pl. 23, fig. 8; pl. 24, figs 4-6; pl. 25, figs $1-5$ (with additional synonymy).
2002. Mantelliceras mantelli (J. Sowerby, 1814); Amédro et al., p. 10 , pl. 3 , fig. 1 ; pl. 4 , fig. 1

2009. Mantelliceras mantelli (J. Sowerby, 1814); Wilmsen et al., p. 114 , text-fig. 3 .

2011. Mantelliceras mantelli (J. Sowerby, 1814); Mosavina and Wilmsen, p. 178, text-figs 3a-e (with additional synonymy).

2011. Mantelliceras mantelli (J. Sowerby, 1814); Kennedy et al., p. 221, figs 11a-c.

?2013. Mantelliceras mantelli (?) Sowerby; Reboulet et al., text-fig. $4 \mathrm{~d}$.

2014. Mantelliceras mantelli (J. Sowerby, 1814); Walaszczyk et al., text-fig. 23i, j.

TYPE: Lectotype, By The subsequent designation of Kennedy (1971, p. 54), is BMNH 43940a from the Lower Cenomanian Chalk Marl of Ringmer, near Lewes, Sussex, the original of J. Sowerby (1814, pl. 55 , lower figure only), reillustrated by Wright and Kennedy (1984, pl. 18, fig. 3a-c).

MATERIAL: UW1517, from the Berekata section. UW1291, 1314, 1319, 1328, from bed 11; UW1294, from beds 11-14; UW0806, 1533, from beds 13-14; UW0792, 0794, 0795, 0814, 1076;1548, from bed 14; UW0819, from bed 23 of the Vohipaly section. There are numerous additional poorly preserved specimens, best referred to as $M$. cf. mantelli: UW1270, from bed 2; UW1302, and 1309, from bed 11; UW0803, from beds 12-14; UW1483, from bed 14, and UW0793, collected loose, and all from the Vohipaly section.

DESCRIPTION: The Madagascan material shows the species to be strongly dimorphic. Specimens such as UW1319 (P1. 2, Figs 1, 3) is an adult microconch 50 $\mathrm{mm}$ in diameter that preserves a $200^{\circ}$ sector of adult body chamber. Coiling is moderately involute, the umbilicus deep, and comprising $23 \%$ of the diameter, with a convex wall and broadly rounded umbilical shoulder. The whorl section is as wide as high, with feebly convex flanks, broadly rounded ventrolateral shoulders and a flattened, feebly convex venter in intercostal section. The costal section is polygonal, with the greatest breadth at the lateral tubercle. On the surviving adapertural part of the phragmocone, and the adapical part of the body chamber, primary ribs arise at the umbilical seam and develop into bullae of various strengths, perched on the umbilical shoulder. These give rise to single straight, prorsirdiate ribs that strengthen across the flanks and develop into a strong mid-lateral bulla, weaker inner ventrolateral bulla, and subequal and feebly clavate outer ventrolateral tubercle, the outer ventrolateral tubercles con- 
nected across the venter by a strong, straight, transverse ventral rib. The primary ribs are separated by a single intercalated rib. These arise low on the flanks, and strengthen to match the primary ribs. Some, but not all, develop a feeble lateral tubercle, and all strengthen to match the primary ribs in strength and tuberculation. Umbilical and lateral tubercles weaken and efface progressively on the adapertural sector of the body chamber, the ribs become feebly flexuous, with inner and outer ventrolateral tubercles persisting. These changes in ornament suggest the specimen to be a near-complete adult.

UW1314 (P1. 3, Figs 1-3) is the nucleus of a macroconch, $68 \mathrm{~mm}$ in diameter. Coiling is moderately involute, the umbilicus comprising $26 \%$ of the diameter, the whorl section depressed, the whorl breadth to height ratio greater than 1.2 in costal section (the preservation is defective). Ten to eleven primary ribs arise on the umbilical wall of the adapertural half whorl, and strengthen into umbilical bullae that give rise to straight prorsiradiate ribs with strong lateral bullae and slightly weaker inner and outer ventrolateral tubercles, the latter linked across the venter by a coarse rib, feebly concave between the clavi. Single intercalated ribs separate successive primaries, and develop comparable inner and outer ventrolateral tubercles.

UW0814 (Pl. 2, Figs 5, 7), UW1328 (Pl. 2, Fig. 6) and UW1076 (Pl. 3, Figs 4, 5) are adult macroconchs. UW0814 and 1328 retain strongly ribbed and tuberculate nuclei that differ in no significant respects from UW1313 (Pl. 3, Figs 1-3). UW 0814 has regularly alternating primary and intercalated ribs throughout. At the adapical end of the body chamber, the primary ribs bear a full complement of tubercles; moving adaperturally, the inner ventrolateral tubercles weaken and efface, followed by the lateral, the umbilical bullae persisting, though weakened, to the greatest preserved diameter. The outer ventrolateral tubercles weaken at the greatest preserved diameter with an undamaged venter. UW1328 (P1. 2, Fig. 6) shows a comparable weakening and loss of tubercles, the venter broad and rounded at the greatest preserved diameter. UW1076 (Pl. 3, Figs 4, 5) is a complete macroconch body chamber $144 \mathrm{~m}$ in diameter. A full complement of tubercles is present on the adapical half. On the adapertural half, only the umbilical bullae persist, and these weaken progressively; one or two long intercalated ribs separate the primaries.

DISCUSSION: Differences between Mantelliceras mantelli and the other principal species referred to the genus are fully reviewed by Wright and Kennedy (1984, pp. 97-126). Of those recognized in the pres- ent faunas and described below, Mantelliceras cantianum Spath, 1926a, has broad, rapidly expanding whorls, the primaries with strong umbilical and lateral bullae, connected by a strong rib, the latter increasing in strength through ontogeny, while the inner ventrolateral tubercles disappear at a relatively early ontogenetic stage. In Mantelliceras dixoni Spath, 1926b, the whorl section is compressed, rounded, the primary ribs with umbilical and inner lateral tubercles linked by a strong rib, and an outer ventrolateral clavus. Inner ventrolateral tubercles are weak, and lost at an early stage. Mantelliceras picteti Hyatt, 1903, has a compressed whorl section, the primary ribs with umbilical bullae, stronger lateral tubercles, conical inner ventrolateral and stronger outer ventrolateral clavi. Intercalated ribs have inner and outer ventrolateral tubercles only. Mantelliceras saxbii (Sharpe, 1857) has a compressed, high whorl section, and numerous flexuous ribs. Most loose all but the outer ventrolateral clavi at an early ontogenetic stage. There may be a feeble lateral bulla in the middle growth stages.

A number of variants with the basic mantelli ribbing and tuberculation described from Madagascar by Collignon (1964; see synonymy) are regarded as synonyms; see discussion in Wright and Kennedy (1984, p. 100).

OCCURRENCE: Commonest in the Mantelliceras mantelli Zone of the Lower Cenomanian, but extending into the succeeding Mantelliceras dixoni Zone. The species ranges from England to Northern Ireland, France, Germany, Russia, Iran, North Africa, KwaZulu-Natal South Africa, Madagascar, southern India, and Japan.

\section{Mantelliceras cantianum Spath, 1926a (Text-fig. 4E, F)}

1926a. Mantelliceras cantianum Spath, p. 82.

1964. Mantelliceras cantianum Spath; Collignon, p. 80, pl. 344, fig. 1532; ?fig. 1533 (var. unituberculata); non fig. 1534 (var. abrupta).

1964. Mantelliceras geyeri Collignon, p. 99, pl. 352, fig. 1560.

1984. Mantelliceras cantianum Spath, 1926; Wright and Kennedy, p. 103, pl. 17, fig. 2; pl. 20, fig. 3; pl. 21, fig. 3; pl. 24, figs. 1, 2, 4-6; pl. 25, figs 1-6; pl. 26, figs 1 , 2, 4, 5; pl. 38, fig. 1 ; text-figs. 25a; $27 \mathrm{e}-\mathrm{n}, \mathrm{j}-1$ (with full synonymy).

1998 Mantelliceras cantianum Spath, 1926a; Kaplan et al., p. 116, pl. 18, figs 5, 6,10, 11; pl. 20, figs 2, 3; pl. 21, figs $1-3$; pl. 26, fig. 6 (with additional synonymy). 
2002. Mantelliceras cantianum Spath, 1926a; Amédro et al., p. 10 , pl. 3, fig. 3 ; pl. 4, fig. 2 .

2011. Mantelliceras cantianum Spath, 1926a; Mosavina and Wilmsen, p. 180, text-figs $4 \mathrm{a}, \mathrm{b}, \mathrm{h}$ (with additional synonymy).

2014. Mantelliceras cantianum Spath, 1926; Walaszczyk et al., text-fig. $24 \mathrm{a}, \mathrm{b}$.

HOLOTYPE: By original designation, BMNH 36834, from the Lower Cenomanian Chalk Marl of Dover, Kent; paratype BMNH C5027 is from the same unit at Lewes, Sussex. They were figured by Sharpe (1857, pl. 18, figs 1, 2) and Wright and Kennedy (1984, pl. 24, figs 2, 6).

MATERIAL: UW1310, from bed 11; UW0775 (cf. cantianum), 0776, 0778 (cf cantianum), from beds 13-14, UW1532 (cf. cantianum), from bed 14 of the Vohipaly section.

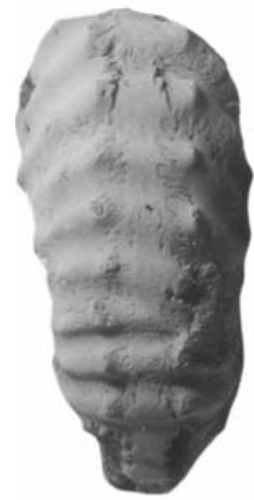

A

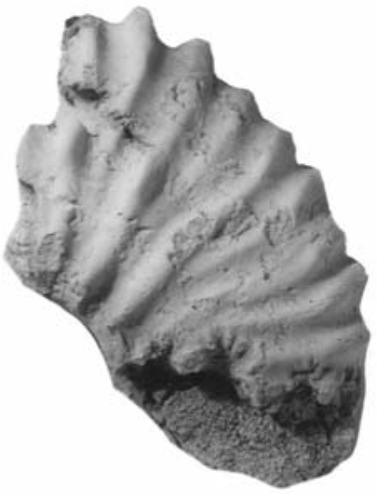

B

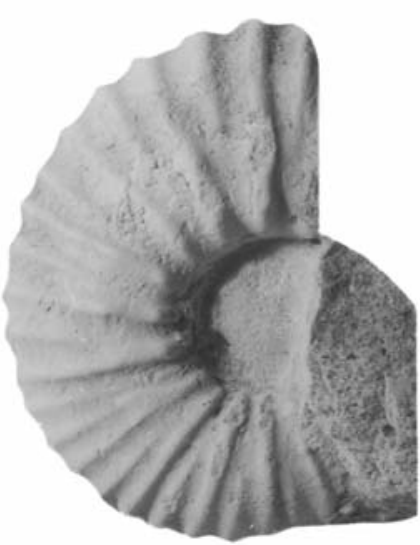

E

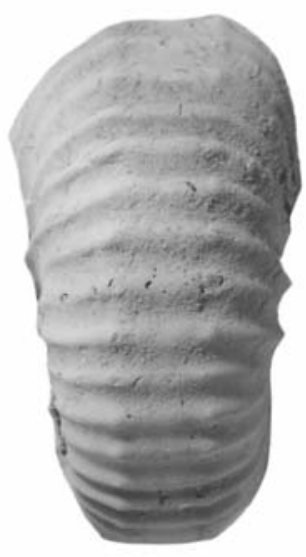

$\mathrm{F}$
DESCRIPTION: The best-preserved specimen is UW1310 (Text-fig. 4E, F), a phragmocone $53 \mathrm{~mm}$ in diameter. The deep umbilicus comprises $28 \%$ of the diameter, the umbilical wall high, very feebly convex, the umbilical shoulder broadly rounded, the whorl section depressed reniform in intercostal section and depressed polygonal in costal section, with a whorl breadth to height ratio of 1.3 , the greatest whorl breadth at the lateral tubercle. Ten primary ribs arise on the umbilical wall on the adapertural half of the outer whorl. They strengthen into weak to strong bullae, perched on the umbilical shoulder. The bullae give rise to strong, straight, prorsiradiate primary ribs that bear progressively strengthening lateral bullae and rounded to feebly clavate outer ventrolateral clavi, linked across the venter by a strong transverse rib. The primary ribs are separated by one, rarely two intercalated ribs; lacking a lateral bulla, they strengthen
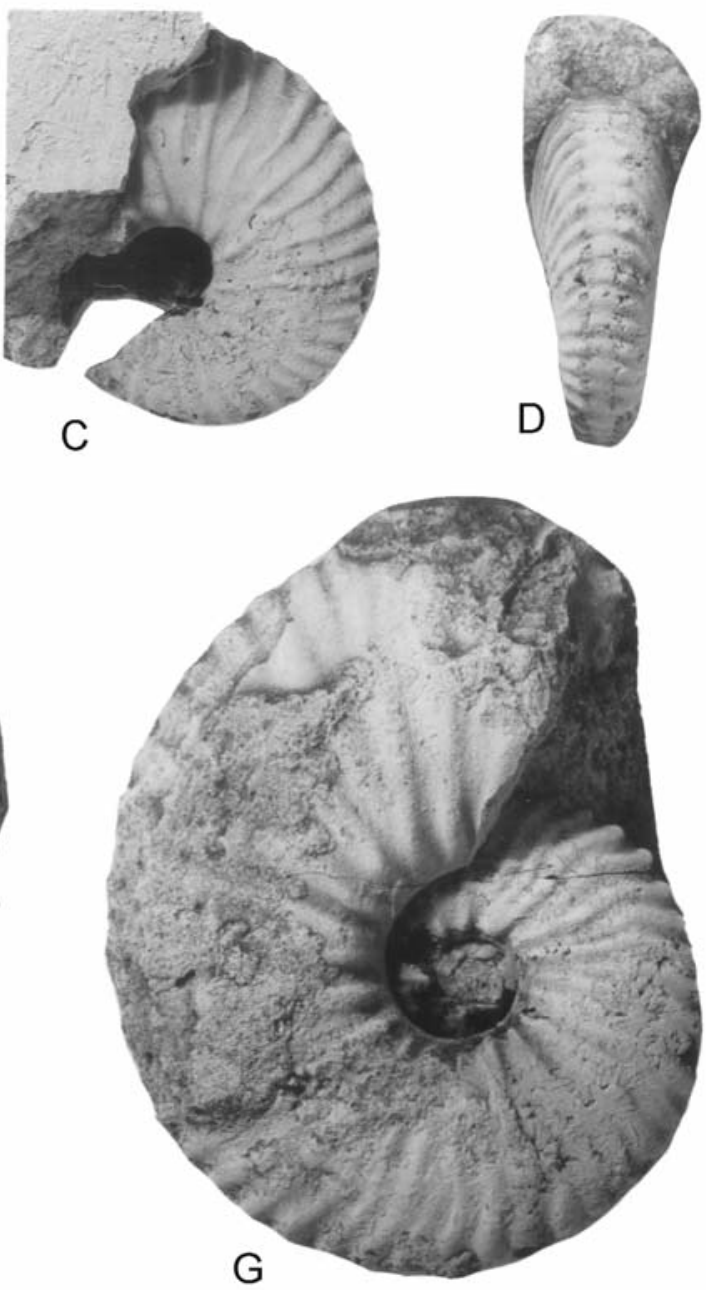

Text-fig. 4. A, B - Mantelliceras picteti Hyatt, 1903, UW0802, from beds 13-14 of the Vohipaly section. C, D, G-Mantelliceras saxbii (Sharpe, 1857). C, D - UW1065, from Berekata; G - UW1546, from bed 14 of the Vohipaly section. A. E, F - Mantelliceras cantianum Spath, 1926a, from Bed 11 of the Vohipaly section. All specimens are from the Lower Cenomanian, Mantelliceras dixoni Zone. Figures are $\times 1$ 
across the flanks, and have an outer lateral, ventrolateral and ventral development identical to that of the primary ribs, to give a total of 20-21 ribs at the ventrolateral shoulder of the adapertural half whorl of the specimen.

DISCUSSION: Differences from other species of Mantelliceras in the present material are outlined above.

OCCURRENCE: Lower Cenomanian, Mantelliceras mantelli and M. dixoni Zones. The geographic distribution extends from southern England across France, northern Spain, Germany, Switzerland, Romania (?), Iran, Central Tunisia, KwaZulu-Natal in South Africa, Madagascar, and Japan.

Mantelliceras saxbii (Sharpe, 1857)

(Pl. 4, Figs 3-6; Text-fig. 4C, D, G)

1857. Ammonites saxbii Sharpe, p. 45, pl. 20, fig. 3.

1964. Mantelliceras hyatti Spath; Collignon, p. 71, pl. 340, figs 1518-1520.

1964. Mantelliceras hyattiforme Collignon, p. 71, pl. 340, figs 1521-1524.

1964. Mantelliceras biroi Collignon, p. 84, pl. 346, figs 1540, 1541; pl. 351, fig. 1540.

1964. Mantelliceras agrawali Collignon, p. 86, pl. 347, figs 1542, 1543.

1964. Mantelliceras agrawali var. concava Collignon, p. 86, pl. 347, fig. 1544 .

1964. Mantelliceras agrawali var. celsa Collignon, p. 87, pl. 347, fig. 1545.

1964. Mantelliceras spissum Collignon, p. 90, pl. 348, figs 1549, 1550.

1984. Mantelliceras saxbii (Sharpe, 1857); Wright and Kennedy, p. 121, pl. 23, fig. 4; pl. 32, figs 1-3; pl. 33, figs $1-4$; pl. 34, figs $1-4$; pl. 35, figs $1-5$; pl. 36, figs 2, 3; pl. 39, fig. 1; text-figs 25b-d, i; 26b; 281-p (with full synonymy).

1998. Mantelliceras saxbii (Sharpe, 1857); Kaplan et al., p. 118 , pl. 18 , figs 1 , 9; pl. 20, fig. 1; pl. 24, fig. 3 ; pl. 26, figs 7, 8; pl. 41, figs 2, 4 (with additional synonymy).

?2003. Mantelliceras saxbii (Sharp); Kawabe et al., pl. 2, fig. 1.

?2005. Mantelliceras saxbii (Sharpe, 1857); Aly et al., p. 370 , pl. 7, fig. 2 only, non 3 .

2011. Mantelliceras saxbii (Sharpe, 1857); Mosavina and Wilmsen, p. 182, text-fig. 4C, F, G (with additional synonymy).

2014. Mantelliceras saxbii (Sharpe, 1867); Walaszczyk et al., text-fig. $24 \mathrm{~h}$.
LECTOTYPE: By the subsequence designation of Wright and Wright 1951, p. 38 is no. 7763 in the collections of the British Geological Survey, the original of Sharpe 1857, pl. 20, fig. 3.

MATERIAL: UW1065, from Berekata A. UW1296, from bed 11; UW0800, 0805, 1313 (cf. saxbii) from beds 12-14; UW1303, from bed 13 (cf. saxbii); UW0785, 0788 (cf. saxbii), 0789, 0790, 0809, 0810, 0812 (cf. saxbii), 0817, 1300, 1498, 1524 (cf. saxbii) 1528, 1534-6, from beds 13-14; UW0780, 0787, 1546, from bed 14; UW1548, from bed 15; UW1497, collected loose, all from the Vohipaly section.

DESCRIPTION: UW1065 (Text-fig. 4C, D) is a typical juvenile, $37 \mathrm{~mm}$ in diameter. Coiling is involute, the umbilicus comprising $23.5 \%$ of the diameter, shallow, with a low wall, and quite narrowly rounded umbilical shoulder. The whorl section is compressed, with a whorl breadth ratio of 0.8 approximately, the inner and middle flanks flattened and subparallel, the outer flanks feebly convex and convergent. The ventrolateral shoulders are broadly rounded, the venter feebly convex in costal section. Nine primary ribs per half whorl arise on the umbilical wall, and strengthen into tiny bullae, perched on the umbilical shoulder. These give rise to single delicate straight prorsiradiate primary ribs that bear a tiny delicate lateral tubercle. The ribs flex slightly backwards from this tubercle, and are very feebly concave, strengthen, and link to a small ventral clavus, the clavi linked across the venter by a low, broad, very feebly convex rib. Between one and three long and short ribs intercalate between successive primaries; lacking a lateral tubercle, they strengthen and match the primary ribs on outer flank, ventrolateral shoulders and venter.

UW1546 (Text-fig. 4G) is the best-preserved of the larger specimens, $84 \mathrm{~mm}$ in diameter, with a $120^{\circ}$ sector of body chamber preserved. The coiling on the outer whorl is eccentric, and the specimen may be an adult microconch. The umbilicus comprises $20 \%$ of the diameter approximately at a diameter of $60 \mathrm{~mm}$, and $25 \%$ at the greatest preserved diameter. There are 20 primary ribs on the outer whorl. They arise on the umbilical wall, and strengthen into small umbilical bullae, perched on the umbilical shoulder on the phragmocone, but migrating outwards onto the innermost flank at the greatest preserved diameter. They give rise to one, sometimes two ribs, with additional ribs intercalating, to give a total of between 40 and 50 ribs per whorl at the ventrolateral shoulder. The ribs are straight and prorsiradiate on the inner to middle flank, flexing back and feebly concave on the outer flank, broadening, and 
linking to a feeble inner ventrolateral tubercle at the beginning of the outer whorl that is soon lost. All develop an outer ventrolateral clavus that persists to the end of the phramocone, the ribs connected across the venter by a coarse transverse rib. The ribs coarsen on the outer flank and ventrolateral shoulder of the body chamber, the venter rounds, and the outer ventrolateral clavi are lost. UW1296 (P1. 4, Figs 3, 4) links the nucleus described above and the larger specimens in the collection. The inner whorls, to a diameter of $32 \mathrm{~mm}$ approximately, have coarser and more flexuous ribs than UW10065 (Text-fig. 4C, D), and lack a lateral bulla. The outer whorl, preserved to a maximum whorl height of $34 \mathrm{~mm}$, has lost all tubercles apart from the feeble umbilical bullae, the ribs near-straight. It may be a further incomplete microconch.

\section{DISCUSSION: See above.}

OCCURRENCE: Mantelliceras saxbii ranges throughout the Lower Cenomanian, but is commonly only in the middle of the substage, being represented by rather stout forms in the lower part of its range and by densely and flexuously ribbed forms in the upper part. It is widespread in southern England, the Boulonnais, Haute Normandie, Maine, Sarthe and Provence in France, northern Spain, Switzerland, Poland, Romania, Bulgaria, Russia, Iran north of the Zagros, Khazakhstan, north Africa, Angola, KwaZulu-Natal in South Africa, Madagascar, and Japan.

Mantelliceras picteti Hyatt, 1903

(P1. 7, figs 5, 6, 7; Text-fig. 4A, B)

1859. Ammonites Mantelli Sowerby; Pictet and Campiche, p. 200 , pl. 26, fig. $3, ? 1,2$.

1903. Mantelliceras picteti Hyatt, p. 114 [pars].

1964. Mantelliceras antanimangaense Collignon, p. 83, pl. 346, fig. 1539.

1964. Mantelliceras patens Collignon, p. 87, pl. 347, fig. 1546.

1964. Mantelliceras crassecostatum Collignon, p. 95, pl. 350, figs 1553, 1555, ?1554.

1972. Mantelliceras (Promantelliceras) picteti collignoni Thomel, p. 32, pl. 4, figs 4, 5.

1984. Mantelliceras picteti Hyatt, 1903; Wright and Kennedy, p. 117, pl. 27, figs 1-5; pl. 28, figs 1-3; textfigs $25 \mathrm{~g}, 27 \mathrm{i}, \mathrm{n}-\mathrm{q}$ (with full synonymy).

1985. Mantelliceras tenue Spath; Immel and Seyed-Emami, p. 100 , pl. 4, fig. 7.

1986. Mantelliceras picteti Hyatt; Kennedy et al., p. 35, figs $8 \mathrm{~d}-\mathrm{e}, 9,10 \mathrm{a}-\mathrm{c}, 11 \mathrm{a}-\mathrm{d}$.
1992. Mantelliceras picteti Hyatt; Thomel, pl. 2, fig. 1; pl. 26, fig. 4 ; pl. 27, fig. 1 ; pl. 28 , fig. 8 .

?2005. Mantelliceras cf. picteti Hyatt, 1903; Matsumoto and Toshimitsu, p. 32, text-fig. 3 .

TYPE: The lectotype, designated by Wright and Kennedy 1984, p. 118, is the original of Pictet and Campiche 1859, pl. 26, fig. 3 from the Cenomanian of Sainte Croix, Switzerland.

MATERIAL: UW0777 and 0802, from beds 13-14; UW0815, from bed 14 of the Vohipaly section.

DESCRIPTION: UW0777 (Pl. 4, Figs 5, 6) consists of a nucleus $18 \mathrm{~mm}$ in diameter and part of the succeeding whorl, preserved to a whorl heigh of $18 \mathrm{~mm}$. The coiling is moderately involute, the umbilicus relatively shallow, the umbilical wall feebly convex, the umbilical shoulder broadly rounded. The whorl section is compressed, rounded-trapezoidal in intercostal section, with a whorl breadth to height ratio of 0.87 in costal section, the greatest breadth at the lateral bullae. Straight prorsiradiate primary ribs arise from small umbilical bullae and bear lateral bullae, inner ventrolateral bullae and outer ventrolateral clavi, linked across the venter by a low, broad, transverse rib. Single long intercalated ribs separate the primaries; they lack a lateral bulla, but are otherwise identical in outer flank, ventrolateral shoulder and ventral development as the primary ribs. UW0802 (Text-fig. $4 \mathrm{~A}, \mathrm{~B})$ although only a fragment, with a maximum preserved whorl height of $28 \mathrm{~mm}$ and a whorl to breadth height ratio of 0.94 in costal section, shows the same alternation of primary and secondary ribs, the primaries with a strong lateral bulla. UW0813 (P1. 4, Fig. 7) is a damaged individual with a maximum measurable diameter of $86 \mathrm{~mm}$. It is septate to a diameter of $75 \mathrm{~mm}$, and retains a further $180^{\circ} \mathrm{sec}-$ tor of worn and abraded body chamber. The umbilicus comprises $18 \%$ of the diameter; the whorl breadth to height ratio is 0.8 . Ornament on the phragmocone consists of alternating primary ribs with umbilical bullae, strong lateral bullae, weaker inner ventrolateral bullae and stronger outer ventrolateral clavi alternating with secondary ribs that lack a lateral bulla, as in the previous specimens. The ribs are connected across the venter by a broad, straight transverse rib; the ventral profile is markedly concave in costal section. At the largest preserved diameter, the lateral bullae are lost, and the venter broadens and rounds. The specimen is very worn, but the inner ventrolateral tubercles appear to be lost, and the outer weakened. It may be an adult microconch. 
OCCURRENCE: Mantelliceras picteti ranges throughout the lower Lower Cenomanian M. mantelli Zone, and on the basis of the present records, its extension into the succeeding $M$. dixoni Zone is confirmed. There are records from southern England, France from the Boulonnais to Sarthe, Argonne, Isère and Provence, Germany, northern Spain, Switzerland, Podolia, Crimea, Iran and Madagascar.

\section{Mantelliceras dixoni Spath, 1926b (Pl. 4, Figs 1, 2; Text-fig. 5)}

1850. Ammonites Milletianus ?d'Orbig.; J. de C. Sowerby in Dixon, p. 359, pl. 29, fig. 15.

1926b. Mantelliceras dixoni Spath, p. 427, 430.

1964. Mantelliceras pseudohyatti Collignon, p. 73, pl. 341, fig. 1525.

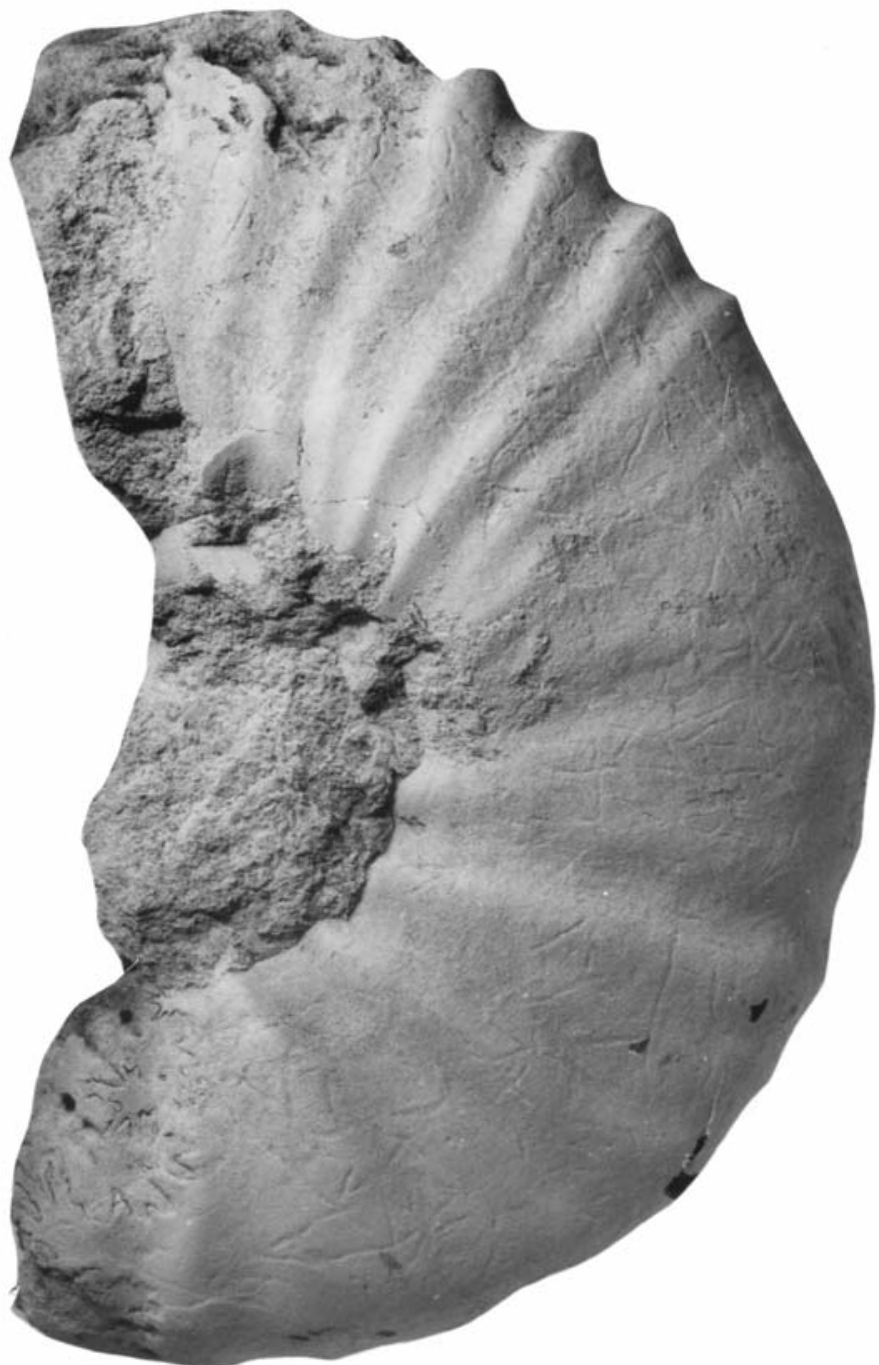

1964. Mantelliceras lateretuberculatum Collignon, p. 90, pl. 348, fig. 1548; pl. 349, fig. 1552.

1984. Mantelliceras dixoni Spath, 1926b; Wright and Kennedy, p. 124, pl. 37, figs 1-6; pl. 38, figs 2-5; pl. 39, figs $2-5$; pl. 40, figs $1-5$; text-figs $21 \mathrm{~d}-\mathrm{f}$; $22 \mathrm{a}-$ g; 23; 25e, j; 27m, r, s (with full synonymy).

1998. Mantelliceras dixoni Spath, 1926b; Kaplan et al., p. 122, pl. 20, figs 4, 5; pl. 23, figs $1-7$; pl. 24, figs 7-9; pl. 54, fig. 2 (with additional synonymy).

?2005. Mantelliceras cf. dixoni Spath, 1926; Matsumoto and Toshimitsu, p. 35, text-fig. 4.

?2013. Mantellliceras dixoni (?) Spath; Reboulet et al., textfig. $4 \mathrm{e}$.

2014. Mantelliceras dixoni Spath, 1926; Walaszczyk et al., text-fig. 23a, b.

TYPE: The holotype, by original designation, is BMNH C33630, from the Lower Chalk of Sussex,

Text-fig. 5. Mantelliceras dixoni Spath, 1926b, UW1254, collected loose at the Vohipaly section, Lower Cenomanian, Mantelliceras dixoni Zone. Figures are $\times 1$ 
the original of J. de C. Sowerby in Dixon 1850, pl. 29, fig. 12, refigured by Wright and Kennedy 1984, pl. 37 , fig. 6 .

MATERIAL: UW1323-26, from bed 11 of the Vohipaly section.

DESCRIPTION: UW1323 (Pl. 4, Figs 1, 2) is a single camera and body chamber with a maximum preserved diameter of $106 \mathrm{~mm}$. Coiling is moderately evolute, the umbilicus comprising $36 \%$ of the diameter approximately, the umbilicus shallow and convex, the umbilical shoulder broadly rounded, both costal and intercostal sections slightly depressed, reniform, with a costal whorl to breadth to height ratio of 0.97 , the greatest breadth low on the flanks. On the adapical part of the body chamber, strong distant primary ribs arise at the umbilical seam, and are well developed on the umbilical wall, strengthening into well-developed bullae on the umbilical shoulder. The bullae give rise to a strong straight rectiradiate rib that links to a lateral bulla. The rib extending from the bulla is lower than that connecting the bullae on the inner flank, although still strong. It passes straight across the flanks and ventrolateral shoulders, and is near-transverse across the venter. Two long intercalated ribs, lacking a lateral bulla, separate the adapical primaries; five long and short intercalatories separate the succeeding primary, two of the intecalatories arising as a pair on the innermost flank. The adapical primary rib lacks a lateral tubercle, and indicates the specimen to be near-adult. UW1234 (Text-fig. 5) is an adult body chamber with a maximum preserved diameter of $147 \mathrm{~mm}$, the umbilicus comprising $33 \%$ of the diameter, the umbilical wall convex and subvertical at the adapical end of the body chamber, and inclined outwards at the adapertural end. The umbilical shoulder is very broadly rounded, the whorl section compressed, ovoid, with a costal whorl breadth to height ratio of 0.8 at the adapical end, the greatest breadth low on the flanks. On the adapical two thirds of the body chamber, ornament consists of alternating low, broad, coarse primary and secondary ribs. The primaries arise from a blunt umbilical bulla, linked to a blunt, effacing lateral bulla by a straight rib. The bulla gives rise to a lower, slightly flexuous rib that coarsens, broadens, and passes near-straight across the venter. The intercalated ribs arise low on the flank, and strengthen to match the primaries on the outer flank, ventrolateral shoulders and venter. Ornament changes abruptly on the adapertural third of the body chamber. Seven primary ribs arise at the umbilical seam, and are relatively weak, flexuous and prorsiradiate across the flanks, lacking both an umbilical and lateral bulla. They have a markedly asymmetric profile on the venter, with a steep adapertural face.

DISCUSSION: UW1323 is near identical to the holotype of Mantelliceras orbignyi (Collignon, 1937) (p. 45 (24), pl. 10), a synonym of dixoni, refigured by Wright and Kennedy (1984, text-fig. 21d-f). The distinctive strong bar-rib linking umbilical and lateral bulla on the primary ribs, and loss of inner ventrolateral tubercles is immediately diagnostic of adult dixoni body chambers. UW1234 has a quite different style of ribs, broad and blunt, rather than narrow, high, and distant. It is referred to dixoni on the basis of the presence of umbilical and lateral bullae, linked by a strong rib on the primaries. Large macroconchs from the Sables et Grès de Lamnay of Sarthe have comparably coarse ribs (Wright and Kennedy 1984, text-fig. 23), but not as blunt as those of the present specimen.

OCCURRENCE: The species is restricted to the upper Lower Cenomanian Mantelliceras dixoni Zone. There are records from southern England, the Boulonnais, Haute Normandie, Sarthe, Jura, Basses Alpes, and Bouches-du-Rhône in France, Germany, Switzerland, Romania, Iran north of the Zagros(?), northern Mexico, El Salvador Japan (?), and Madagascar.

Genus Sharpeiceras Hyatt, 1903

TYPE SPECIES: By original designation by Hyatt 1903, p. 111: Ammonites laticlavius Sharpe, 1855, p. 31, pl. 14, fig. 1 .

Sharpeiceras mocambiquense (Choffat, 1903) (Pl. 4, Figs 8, 9; Pl. 6, Fig. 2)

1903. Acanthoceras laticlavium (Sharpe) var. moçambiquensis Choffat, p. 25, pl. 4, fig. 3; pl. 7, fig. 1.

1987. Acanthoceras laticlavium var. moçambiquensis Choffat; Wright and Kennedy, p. 127.

1998. Sharpeiceras mocambiquense (Choffat); Matsumoto and Toshimitsu, p. 624, pls 2, 3.

1999. Sharpeiceras mocambiquense (Choffat); Matsumoto et al., p. 19, text-fig. 1 .

TYPE: The holotype, by monotypy, is the original of Choffat, 1903, p. 25, pl. 4, fig. 3; pl. 7, fig. 1, from the Cenomanian of Conducia in northern Mozambique.

MATERIAL: UW1526 and1482, from bed 13; UW0784 from beds $13-14$ of the Vohipaly section. 
DESCRIPTION: UW1526 (Pl. 4, Figs 8, 9) is a $120^{\circ}$ whorl fragment of an internal mould of a phragmocone with a maximum preserved whorl height of $62 \mathrm{~mm}$ and a whorl breadth to height ratio of 0.48 . The umbilicus is shallow, with a feebly convex vertical wall and broadly rounded umbilical shoulder. The whorl section is subrectangular, the flanks flattened and converging to rounded ventrolateral shoulders and a very feely convex venter. Seven primary ribs arise at the umbilical seam and sweep back and are feebly concave across the umbilical wall, strengthening into small umbilical bullae. The bullae give rise to low, straight prorsiradiate ribs that bear well-develop mid-lateral and weaker outer lateral bullae, rounded inner, and stronger outer ventrolateral clavi. There are occasional intercalated ribs, with mid- and outer lateral, inner and outer ventrolateral tubercles. The venter is nearsmooth. UW0784 is a fragment from the adapical end of a body chamber, with a maximum preserved whorl height of $91 \mathrm{~mm}$ and a whorl breadth to height ratio of 0.65 approximately. The specimen is very worn, and only outer lateral bullae, conical to feebly clavate inner, and strongly clavate outer ventrolateral tubercles are preserved. As with the previous fragment, the venter is smooth between the clavi. UW1482 (Pl. 6, Fig. 2 ) is a $60^{\circ}$ whorl fragment of body chamber with only one flank preserved; the estimated maximum whorl height is $110 \mathrm{~mm}$ approximately. Parts of five coarse, distant ribs are preserved. The ribs sweep back across the umbilical wall, and strengthen into prominent umbilical bullae. These give rise to a strong straight rectiradiate rib, with strong mid-lateral bullae, stronger outer lateral bullae, and conical inner ventrolateral tubercles. The ventral region is not preserved.

DISCUSSION: UW1526 has suffered a degree of post-mortem crushing, but was certainly very compressed. UW0784, with a whorl breadth to height ratio of 0.65 , has comparable proportions to the large Madagascan specimen described by Matsumoto and Toshimitsu (1999) at the same diameter. The key feature linking the present specimens to material previously referred to mocambiquese is the presence of an outer lateral tubercle from an early ontogenetic stage. This separates it from S. laticlavium (Sharpe, 1855) (see revision in Wright and Kennedy 1987, p. 127, pl. 41, fig. 4; text-figs 29, 30, 34a), Sharpeiceras schlueteri Hyatt, 1903 (see revision in Wright and Kennedy 1987, p. 129, pl. 41, figs 1, 3; text-figs 32, 33j, 34d, e), Sharpeiceras florencae Spath, 1925 (p. 198, pl. 37) and its possible synonyms (see Howarth 1985, p. 86, figs 15-19, and Matsumoto and Toshimitsu 1998, p. 622, pl. 1). The Sharpeiceras aff schlueteri of Hayakawa and Takahashi (2000 p. 8, pls 1, 2; text-fig. 2) has five rows of tubercles and a very compressed whorl section with a costal whorl breadth to height ratio of 0.48 according to their text-fig. 2, as in UW1526, and may be better compared to $S$. mocambiquense. Sharpeiceras kikuae Matsumoto and Kawashita in Nishida et al. 1996 (p. 186, pl. 5, fig. 1; Matsumoto and Kawashita 1998, p. 92, text-figs 3, 4) has five rows of tubercles, but a wider umbilicus and much lower whorls than mocambiquense, the flanks markedly convex, rather than flattened and subparallel.

OCCURRENCE: Lower Cenomanian of northern Mozambique, Madagascar, and Japan.

\section{Sharpeiceras cf. florencae Spath, 1925} (Pl. 6, Fig. 1)

\section{Compare:}

1925. Sharpeiceras florencae Spath, p. 198, pl. 37.

1985. Sharpeiceras florencae Spath; Howarth, p. 86, textfigs 15-19 (with full synonymy).

1998. Sharpeiceras florencae Spath, 1925; Matsumoto and Toshimitsu, p. 622, pl. 1 (with additional synonymy).

TYPE: The holotype, by monotypy, is the original of Spath, 1925, p. 19, pl. 37, in the collections of the Ditsong Museum of Natural History (formerly the Transvaal Museum), Pretoria, from southern Mozambique.

MATERIAL: UW 1259, from bed VH10 of the Vohipaly section.

DESCRIPTION: The specimen is a $60^{\circ}$ sector of body chamber, with a maximum preserved whorl height of $81 \mathrm{~mm}$. The intercostal whorl section is compressed, with a whorl breadth to height ratio of 0.72 , the flanks feebly convex, subparallel, the ventrolateral shoulders broadly rounded, the venter feebly convex. The estimated costal whorl breadth to height ratio is 0.75 aproximately, the greatest breadth at the lateral bulla. Parts of four ribs are preserved. They are strong, coarse and distant, with a strong umbilical and lateral bulla. There is a stronger ventrolateral node, differentiated into an inner and outer ventrolateral tubercle on the adapical two ribs; on the succeeding rib, these have merged into a single conical-bullate tubercle.

DISCUSSION: Although only a fragment, the absence of a lateral tubercle, poor differentiation of inner and outer ventrolateral tubercles that ultimately fuse into a single node, immediately distinguishes this specimen 
from $S$. mocambiquense. Amongst described species, it compares most closely with $S$. florencae in terms of whorl section, rib spacing and flank tuberculation, and in the fusion of ventrolateral tubercles on the body chamber. Howarth (1985), to which the reader is referred, placed a number of species into the synonymy of florencae.

OCCURRENCE: As for material.

Sharpeiceras falloti (Collignon, 1931)

(Pl. 5, Figs 1-14)

1931 Acanthoceras (Mantelliceras) falloti Collignon, p. 81(41) (pars), pl. 8 (4), figs 9, 10, non 11, 12.

TYPES: The lectotype, here designated, is the original of Collignon 1931, pl. 8 (4), fig. 10, from the Cenomanian east of Antsirane, Madagascar. A paralectotype, the original of Collignon 1931, pl. 8 (4), fig. 9 is from the Cenomanian of the Vallée de la Betaitra, Madagascar. Both of these specimens are in the collections of the Muséum National d'Histoire Naturelle, Paris. Two further paralectotypes (Collignon, 1931, pl. 8 (4), figs 11, 12), were from the Cenomanian of the Skoenberg in northern KwaZulu-Natal, South Africa, and may belong to a different species, as discussed below.

MATERIAL: UW0844, 0851, 0861, and 1544, from bed 21 of the Vohipaly section.

DESCRIPTION: The earliest growth stage seen is the penultimate whorl of UW0851, a $120^{\circ}$ whorl sector with a maximum preserved whorl height of $17.4 \mathrm{~mm}$ (P1. 5, Figs 6, 7). Coiling is evolute, the umbilicus of moderate depth, the umbilical wall subvertical, and feebly convex. The umbilical shoulder is broadly rounded, the whorl section compressed, the flanks feebly convex and subparallel, the ventrolateral shoulders broadly rounded, the venter flattened. The costal whorl section is depressed polygonal, with the greatest breadth at the lateral tubercle. There are nine primary ribs on the fragment. They arise at the umbilical seam, and are coarse, straight and prorsirsdiate on the umbilical wall. They strengthen into small umbilical bullae, which give rise to single coarse straight primary ribs, separated by interspaces of comparable width. All ribs bear a strong lateral tubercle, and a stronger, feebly clavate inner ventrolateral tubercle. A strong, high rib links to a much stronger, subspinose outer ventrolateral clavus. These clavi are linked across the venter by a broad transverse rib, the rib profile markedly concave between the clavi. The outer whorl of this specimen (Pl. 5, Figs 9, 10) is a $90^{\circ}$ sector of body chamber with a maximum preserved whorl height of $41.5 \mathrm{~mm}$. Ornament is preserved on one flank only. Parts of ten ribs survive on the fragment. The ribs arise at the umbilical seam, and are coarse and straight on the umbilical wall, strengthening into a small bulla, perched on the umbilical shoulder. The bullae give rise to coarse straight prorsirasdiate ribs, which strengthen across the flanks. They bear a small inner lateral bulla, a stronger outer lateral bulla and an inner ventrolateral clavus that is closer to the outer lateral bulla than the much stronger blunt, transversely elongated outer ventrolateral horn. The horns are linked across the venter by a low, broad rib, the costal whorl profile deeply concave between the horns. UW0844 (Pl. 5, Figs 1-3) is a body chamber $66 \mathrm{~mm}$ in diameter with a slightly depressed costal whorl section, the greatest breadth at the strong inner to mid-lateral bullae, and a full complement of five rows of tubercles. UW0861 (Pl. 5, Figs $12,13)$ is a further body chamber, $70 \mathrm{~mm}$ long, with comparable ornament. UW1544 (Pl. 5, Figs 11, 14) is a complete adult $83 \mathrm{~mm}$ in diameter. The sutures are largely concealed by a limonite coating, but there appears to be a $180^{\circ}$ sector of body chamber present. Coiling is evolute, the umbilicus comprising $41 \%$ at the greatest preserved diameter. There are an estimated 28-30 ribs on the outer whorl. All are primaries. The style of the ribs is as in the previous specimens. At the adapical end of the outer whorl, the ribs bear four rows of tubercles only: relatively weak umbilical bullae, strong, subspinose lateral bullae, strong inner ventrolateral clavi, and strong outer ventrolateral horns. A weak outer lateral tubercle appears on a few ribs on the adapertural part of the phragmocone and adapical part of the body chamber. Following a damaged portion, the adapical three of the last four ribs have a weak umbilical bulla, weak inner ventrolateral bulla and a strong outer ventrolateral horn, the horns linked across the venter by a high rib, the costal profile deeply concave between the horns.

DISCUSSION: The small adult size distinguishes these specimens from all other described adult Sharpeiceras. The earliest whorls seen differ in no significant respects from the lectotype of falloti (Pl. 5, fig. 8). The presence of four rows of tubercles on the early whorls and five on the later part of the phramocone and adapical part of the body chamber distinguish the species from all other Sharpeiceras. Also distinctive is the separation of inner and outer lateral tubercles to maturity. The two specimens from the Skoenberg in north- 
ern KwaZulu-Natal figured by Collignon (1931, pl. 8 (4), figs 11, 12) do not belong here. Specimens in the collection of the Oxford University Museum of Natural History (for example OUM KX4730) from the Skoenberg do not develop a fifth row of tubercles at a diameter seen in the present material.

OCCURRENCE: Lower Cenomanian of Madagascar.

Genus Mrhiliceras Kennedy and Wright, 1985

TYPE SPECIES: Mammites lapparenti Pervinquière, 1907 , p. 312, pl. 14, figs 5, 6; by original designation, by Wright and Kennedy 1985, p. 514.

\section{Mrhiliceras lapparenti (Pervinquière, 1907)}

(P1. 5, Figs 4, 5)

1903. Mammites cf. conciliatus Stoliczka; Pervinquière, pp. 66, 78 .

1907. Mammites lapparenti Pervinquière, p. 312, pl. 14, figs 5,6 .

1964. Metoicoceras swalloviforme Collignon, p. 149 , pl. 375 , fig. 1627.

1964. Metoicoceras besairiei Collignon, p. 149, pl. 375, figs 1628, 1629.

1978. Metoicoceras besairiei Collignon; Lewy and Raab, p. 112, pl. 1, fig. 10.

?1979. Utaturiceras vicinale (Stoliczka); Wiedmann and Schneider, p. 671, pl. 10, figs 2, 5; text-fig. 10.

?1984. Utaturiceras vicinale (Stoliczka); Kaplan et al., pl. 1, fig. 2.

1985. Mrhiliceras lapparenti (Pervinquière, 1907); Kennedy and Wright, p. 516 (pars), figs 1a-c; 2, 3, 4d, h only.

1987. Mrhiliceras lapparenti (Pervinquière, 1907); Wright and Kennedy, p. 137 (pars), pl. 42, figs 3, non 5; textfigs 33f, g only; 34f; non 35a.

2002. Mrhiliceras lapparenti (Pervinquière, 1907); Masumoto and Nishida, p. 187, text-figs 2, 3.

2014. Mrhiliceras[Metoicoceras] besairiei Collignon, 1964; Walaszczyk et al., text-fig. $24 \mathrm{f}$.

TYPES: The holotype, by original designation, is an unregistered specimen in the Sorbonne Collections from Ain el Glaa, Djebel Bireno, Tunisia, the original of Pervinquière 1907, pl. 14, fig. 5, reillustrated by Kennedy and Wright 1985, text-fig. 2a-c and Wright and Kennedy 1987, text-fig. 33f, g. There are three paratypes in the same collection.

MATERIAL: UW1515, from the Vohipaly section.
DESCRIPTION: UW1515 is a $120^{\circ}$ sector of body chamber with a maximum preserved whorl height of 26 $\mathrm{mm}$. The umbilicus comprises an estimated $25 \%$ of the diameter, shallow, with a low, outward-inclined wall and broadly rounded umbilical shoulder. The intercostal whorl section is compressed, with feebly convex, subparallel flanks, broadly rounded umbilical shoulders and a very feebly convex venter. The costal whorl breadth to height ratio is 0.66 , the whorl section compressed polygonal, with the greatest breadth at the umbilical bullae. Thirteen ribs are preserved on the fragment. Six of these are primaries. They arise at the umbilical seam and strengthen across the umbilical wall. Some develop a blunt umbilical bulla, others do not. The ribs are coarse, blunt, straight and feebly prorsiradiate on the flanks, and link to a coarse inner ventrolateral bulla, from which a strong rib projects forwards to a blunt outer ventrolateral clavus. These clavi give rise to a progressively weakening prorsiradiate ventral rib that forms an obtuse ventral chevron. The primary ribs are separated by one or two intercalated ribs that arise low on the flanks or at mid-flank. Towards the adapertural end of the specimen, the ornament modifies, with a bulla giving rise to a pair of ribs, of which the adapical bifurcates at midflank. This changing ornament suggests that the body chamber may be that of an adult.

DISCUSSION: Matsumoto (in Matsumoto and Nshida 2002) questioned the proposal of Kennedy and Wright (1985 p. 520) that the compressed species Metoicoceras sakarahense Collignon, 1964 (p. 150, pl. 375, figs 1630-1632) and M. fasciculatum Collignon, 1964 (p. 151, pl. 375, fig. 1633) were intraspecific variants of lapparenti, and his view is followed here. I also now doubt the reference of some German and English material to the species, and this is reflected in the revised synonymy and occurrence data.

OCCURRENCE: Lower Cenomanian of southern England, Central Tunisia, Israel, Japan and Madagascar.

Subfamily Acanthoceratinae de Grossouvre, 1894 Genus Acompsoceras Hyatt, 1903

TYPE SPECIES: Ammonites bochumensis Schlüter, 1871 , p. 1, pl. 1, figs 1-4, by original designation by Hyatt 1903, p. 111; = Ammonites renevieri Sharpe, 1857, p. 44, pl. 20, fig. 2.

Acompsoceras renevierii (Sharpe, 1857)

(Pl. 8, Figs 7, 8) 
1857. Ammonites Renevieri Sharpe, p. 44, pl. 20, fig. 2.

1871. Ammonites Bochumensis Schlüter, p. 1, pl. 1, figs 1-4; pl. 2 , fig. 1.

1987. Acompsoceras renevieri (Sharpe, 1857); Wright and Kennedy, p. 140, pl. 43, fig. 2; text-figs. 34g; 35d-f; 36a-f; 37-40; 43d, e (with full synonymy).

1992. Acompsoceras renevieri (Sharpe, 1857); Thomel, pl. 33, fig. 5 .

1993. Acompsoceras renevieri (Sharpe, 1857); Kennedy and Juignet, p. 146, figs. 1d, f; 2b, c, e, f; 3a-c; 4a, b; 5a, b; $6 \mathrm{c}, \mathrm{d} ; 7 \mathrm{c}, \mathrm{d} ; 8 \mathrm{~d}-\mathrm{h}$.

1998. Acompsoceras renevierii (Sharpe, 1857); Kaplan et al., p. 136, pl. 10, figs 6 , 7; pl. 34; pl. 35; pl. 36, figs $1-3$; pl. 37, figs 4-6; pl. 38; pl. 40; pl. 41, figs 1, 5 (with additional synonymy).

2011. Acompsoceras renevieri (Sharpe, 1857); Kennedy et al., p. 223, text-fig. 12 .

2014. Acompsoceras renevieri (Sharpe, 1857); Walaszczyk et al., text-fig. $24 \mathrm{i}, \mathrm{j}$.

TYPES: The lectotype, designated by Wright and Wright (1951, p. 38), is GSM 7753 (figured by Wright and Kennedy 1987 pl.43, fig. 2), from Blackdown, Isle of Wight, the original of Sharpe 1857, pl. 20, fig. 2. The paralectotypes have not been traced.

MATERIAL: UW1523, from beds 13-14 of the Vohipaly section.

DESCRIPTION: UW1523 is a $180^{\circ}$ sector of phragmocone with a maximum preserved whorl height of $59 \mathrm{~mm}$. The umbilicus is shallow, with a flattened to feebly concave umbilical wall and a broadly rounded umbilical shoulder. The whorl section is compressed, with a whorl breadth to height ratio of 0.58 , the flanks subparallel, feebly convex, with the greatest breadth at mid-flank. The ventrolateral shoulders are broadly rounded in intercostal section, the venter very feebly convex. There are eight low, broad ribs on the umbilical shoulder of the fragment, strengthened into small bullae, and an estimated 15 small ventral clavi. The bullae give rise to one or two ribs, with additional ribs intercalating on the flanks. The ribs are weak, straight and prorsirdiate on the inner and middle flanks, projecting forwards on the outer flank, and linking to the ventral clavi. There is a distinct blunt siphonal ridge.

DISCUSSION: The subdued ornament of this fragment finds a match in one of the paralectotypes of $\mathrm{Am}$ monites essendiensis Schlüter, 1871 (pl. 1, fig. 7, pl. 2, fig. 2, refigured by Kaplan et al. 1998, pl. 37, figs 46 ), a synonym. The species is fully discussed by
Wright and Kennedy (1987 p. 140) and Kaplan et al. (1998, p. 136).

OCCURRENCE: Lower Cenomanian, especially the M. dixoni Zone. There are also records the lower Middle Cenomanian C. inerme Zone. The geographic distribution extends from southern England to Germany, Haute Normandie, Sarthe, and Provence in France, Poland, Algeria, Tunisia, Nigeria (?), and Madagascar.

Acompsoceras tenue Collignon, 1964

(Pl. 7, Figs 1, 4-11; Text-fig. 6A-C, E-F)

1964. Acompsoceras tenue Collignon, p. 109, pl. 357, figs 1572, 1573; pl.358, fig. 1574.

TYPE: The holotype, by original designation, is the original of Collignon 1964, p. 109, pl. 357, fig. 1572, from his gisement 362, Antanimanga (Manera), Madagascar, illustrated here as Text-fig. 6 E, F, in the collections of the Université de Bourgogne, Dijon.

MATERIAL: UW1071, from Bereketa; UW0321, from Berekata A. UW0781, 0813, 0820, 0826, 0830, $0835,0840,0842,0859,0864,1250-1252$, plus fragments and moulds of at least 30 further individuals in the matrix of these and other specimens, from bed 21 of the Vohipaly section.

DESCRIPTION: A series of nuclei (Pl. 7, Figs 1, 4, 7) range from $28-38 \mathrm{~mm}$ in diameter. Coiling is very involute, the tiny umbilicus comprising around $7 \%$ of the diameter, with a flattened wall and rounded umbilical shoulder. The whorl section is very compressed with an estimated whorl breadth to height ratio of 0.4 approximately; the inner and middle flanks are flattened and feebly convergent, the outer flanks very feebly convex and more markedly convergent, the ventrolateral shoulders rounded, the venter narrow, and obtusely fastigiate, with a blunt siphonal ridge. Eight to ten tiny bullae per half whorl perch on the umbilical shoulder. They give rise to delicate flexuous prorsiradiate primary ribs that are concave on the umbilical shoulder and innermost flank, convex on the mid-flank, strengthening, flexing forwards and markedly concave on the outer flank. Some ribs branch on the outer flank, and additional ribs intercalate, so that there are many more ribs at the ventrolateral shoulder than on the inner flank. All ribs bear tiny oblique ventral clavi that give rise to a blunt prorsiradiate rib that forms an obtuse ventral chevron with the siphonal ridge at the apex. UW1252 (Pl. 7, Fig. 8) is a phragmocone with a short sector of body chamber (?) retaining recrystallised shell. It 
has ribbing and tuberculation comparable in style to, but stronger than that of the previous specimens. UW0864 (P1 7 , Figs 5,6$)$ is an internal mould of a phragmocone 60 $\mathrm{mm}$ in diameter, again with the same style of ornament, albeit weaker, and a short sector of near-smooth body chamber. UW0835 (Pl. 7, Figs 9, 10) retains a $200^{\circ}$ sector of body chamber, and has a maximum preserved di- ameter of $86 \mathrm{~mm}$. The phragmocone ornament is as in previous specimens. The body chamber has a whorl breadth to height ratio of 0.45 at the adapical end. The ventral clavi and siphonal ridge are lost, the ventrolateral shoulders become broadly rounded, and the narrow venter feebly convex. There are six very low, radial ribs that broaden across the flanks before disappearing abruptly at

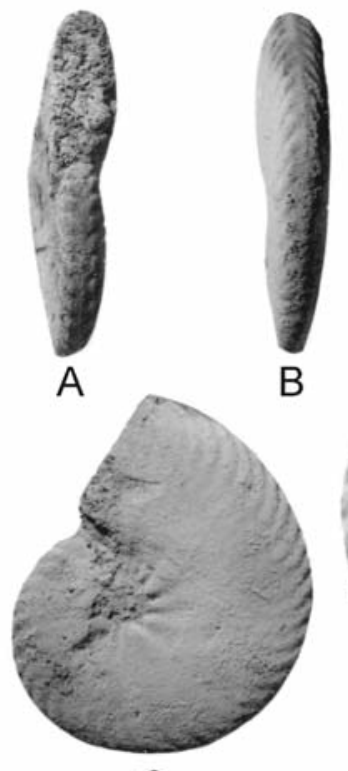

C

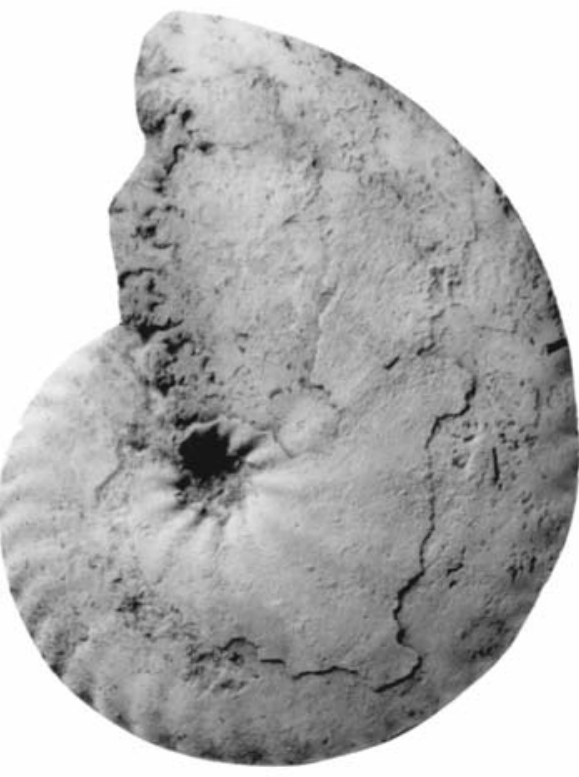

D

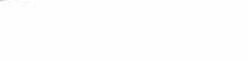

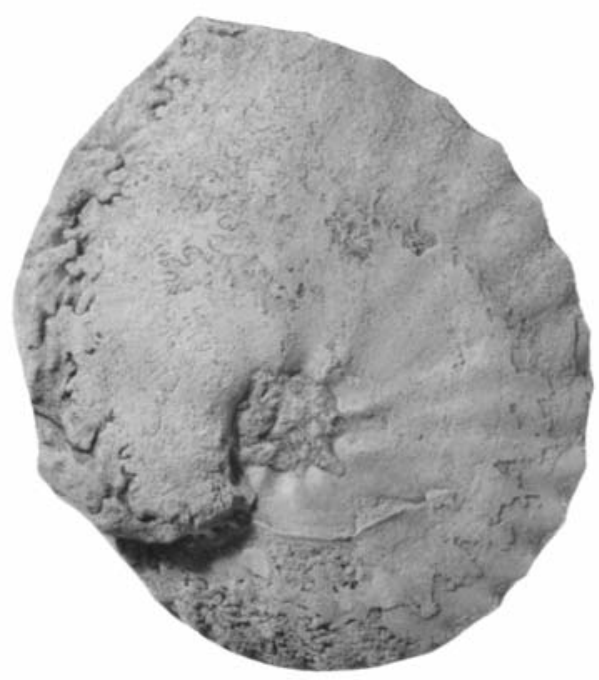

G

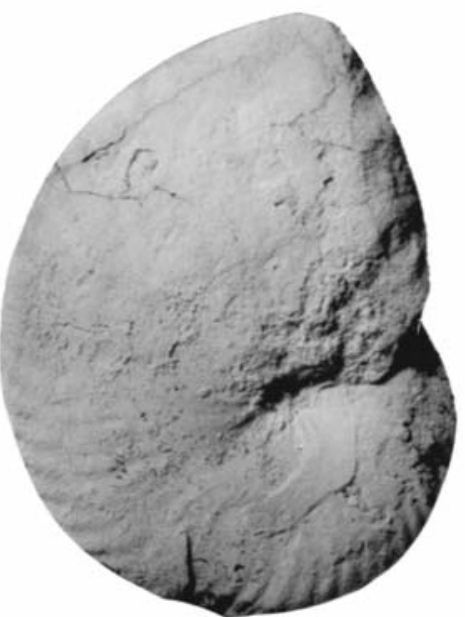

E

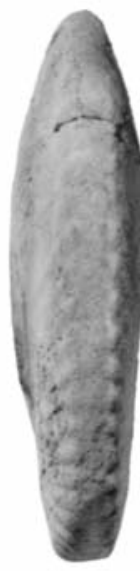

$\mathrm{F}$

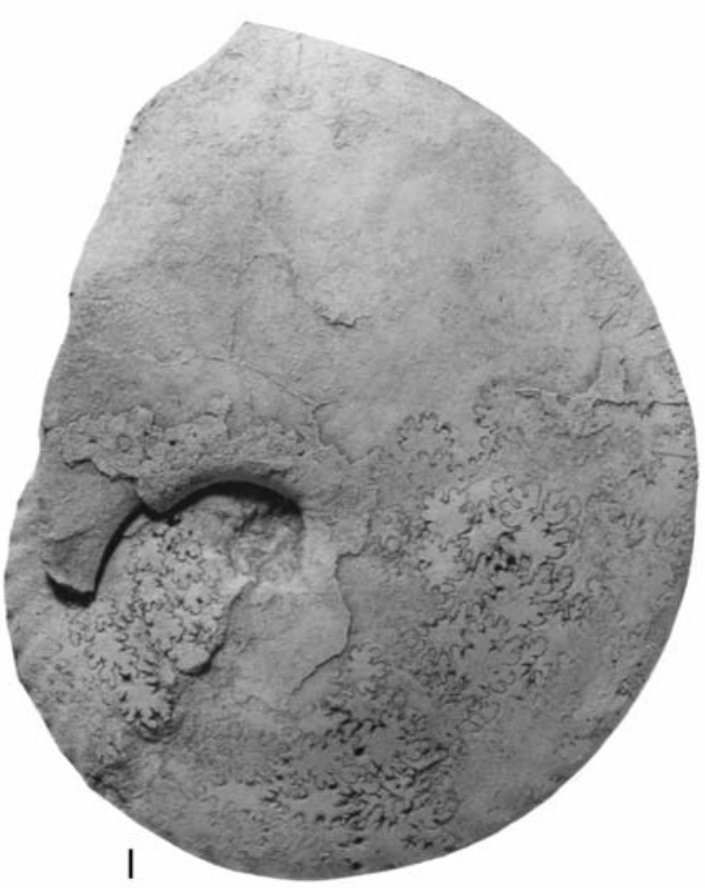

Text-fig. 6. A-C, E, F - Acompsoceras tenue Collignon, 1964. A-C - the original of Collignon, 1964, p. 109, pl. 357, figs 1573; E, F - the holotype, the original of his pl. 358, fig. 1572. D - the original of Acompsoceras sahnii Collignon, 1964, the original of Collignon, 1964, pl. 358, fig. 1576. G, H - the holotype of Acompsoceras antsatramahavelonaense Collignon, 1964, p. 109, pl. 357, fig. 1571. I - the original of Acompsoceras essendiense var. madagascariensis Collignon, 1964, p. 109, pl. 357, fig. 1570. The originals of Figs A-C are from Collignon's locality 632, Chute de la Sakondry en face de Soarano (Manera). D-F, I, are from Collignon's locality 362, Antanimananga (Manera). The original of G, H, is from Antsatramahavelona. All specimens are housed in the collections of the Universite de Bourgogne, Dijon. All figures are $\times 1$. 
a very low spiral ridge, to leave the outer flanks smooth. This is interpreted as a pathological condition, when compared to the body chamber ornament of UW1250 (P1. 7, Fig. 11), a specimen with a $200^{\circ}$ sector of body chamber. Here, the flank ornament extends on to the outer flank as a very broad, low, ribbon-like concave outer termination to a falcoid rib.

Several specimens show the suture (Pl. 7, Figs 6, $9,11)$. The lobes and saddles are deeply incised, with subphylloid folioles on the saddles. E/A is broad and asymmetrically bifid, A deep, narrower, and bifid, $\mathrm{U}_{2}$ smaller, with a minor median incision.

DISCUSSION: The smaller specimens in the present collection differ in no significant respects from Collignon's smallest figured topotype (1964, pl. 357, fig. 1573; Text-fig. 6A-C. herein). The holotype (Collignon 1964 pl. 357, fig. 1572), reproduced here as Text-fig. 6E, F, finds a match in UW1252 (P1. 7, Fig. 8). Collignon described a number of other Acompsoceras from the same locality as the holotype of $A$. tenue that may prove be no more than intraspecific variants and synonyms, although they lie outside the range of variation of the present collection. The holotype and figured topotype of Acompsoceras sahnii Collignon, 1964 (p. 111, pl. 358, figs 1575, 1576) (the latter illustrated here as Text-fig. 6D), has coarser ribs of basically the same style; the ornament of Acompsoceras catzigrasae Collignon, 1964 (p. 112, pl. 358, fig. 1577) (illustrated here as Text-fig. 6G, H) has yet coarser ornament of the same type, although here the ventral clavi are parallel to the ventrolateral shoulder rather than oblique and forming a ventral chevron. Acompsoceras essendiense var. madagascariensis Collignon, 1964 (p. 109, pl. 377, fig. 1570), illustrated here as Text-fig. 6I is also close to the present species,

OCCURRENCE: Lower Cenomanian of Madagascar.

\section{Genus Acanthoceras Neumayr, 1875}

TYPE SPECIES: Ammonites rhotomagensis Brongniart, 1822 pp. 83, 391, pl. 6, fig. 2, by the subsequent designation of De Grossouvre 1894 p. 27.

Acanthoceras sp. juv.

(P1. 7, Figs 2, 3)

MATERIAL: UW1948, from bed M3 of the Mahababoka section.
DESCRIPTION AND DISCUSSION: The specimen is a fragment only, $19 \mathrm{~mm}$ long, with an estimated whorl height of $8 \mathrm{~mm}$. The whorl section is depressed, rounded-rectangular in intercostal section and polygonal in costal section. Four ribs are preserved. All are primaries, with strong umbilical bullae, subspinose inner ventrolateral tubercles, and strong outer ventrolateral and siphonal clavi. The ornament of the specimen is that of a juvenile Acanthoceras (see for example Wright and Kennedy 1987, pl. 46, fig. 4; pl. 49, figs 2,3 ; pl. 50, figs 1,2 ), but the small size renders it specifically indeterminate.

OCCURRENCE: As for material.

Genus Calycoceras Hyatt, 1900, p. 589

(ICZN Generic Name No. 1352)

TYPE SPECIES: By designation under the Plenary Powers (ICZN Opinion No. 557) Ammonites navicularis Mantell, 1822 p. 198, pl. 22, fig. 5 (ICZN Specific Name No. 1633).

Calycoceras sp.

(P1. 1, Figs 1-3)

? 1994. Calycoceras (Newboldiceras) sp. Amédro in Robaszynski et al., p. 412, pl. 12, figs 12-14.

2014. Calycoceras sp. Walaszczyk et al., text-fig. 24g.

MATERIAL: UW1292, from bed 23 of the Vohipaly section.

DESCRIPTION: The specimen is the natural cast of the dorsum of a larger fragment. It is $23 \mathrm{~mm}$ long, and preserves the ventrolateral and ventral regions only. There are 10 ribs on the mould. They appear to be all primaries, and are coarse, narrow and rounded, passing straight across the venter, bearing subequal inner and outer ventolateral and siphonal bullae.

DISCUSSION: This enigmatic mould is assigned to the Acanthoceratinae on the basis of the presence of inner and outer ventrolateral and siphonal tubercles, while the rounded whorl section suggests Calycoceras. The specimen is distinct, however in the shape of the tubercles; all are bullae, whereas in Calycoceras the outer ventrolateral and siphonal clavi are commonly clavate. The horizon of the specimen is also anomalous: Calycoceras is a typically Middle Cenomanian genus, whereas the present specimen is un- 
equivocally Lower Cenomanian. This anomalous record is matched by the occurrence of very similar albeit tiny nuclei with inner and outer ventrolateral and siphonal tubercles in the upper Lower Cenomanian of Tunisia (Robaszynski et al. 1994, p. 412, pl. 12, figs 12-14).

OCCURRENCE: As for material.

Genus Cunningtoniceras Collignon, 1937, p. 64(40) Cunningtoniceras cunningtoni (Sharpe, 1855)

(P1. 8, Figs 1-6)

1855. Ammonites cunningtoni Sharpe, p. 35, pl. 15, fig. 2. 1964. Euomphaloceras euomphalum (Sharpe) var. pervinquierei Collignon, p. 145, pl. 373, fig. 1619.

1987. Cunningtoniceras cunningtoni (Sharpe, 1855); Wright and Kennedy, p. 196, pl. 52, fig. 2; pl. 53, fig. 4; textfigs 76-78 (with full synonymy).

1991. Cunningtoniceras cunningtoni (Sharpe, 1855); Delamette and Kennedy, p. 456, figs 16.1-16.3.

1992. Cunningtoniceras cunningtoni (Sharpe, 1855); Thomel, pl. 38, figs 1, 2; pl. 39, fig. 1; pl. 40, fig. 1.

1993. Cunningtoniceras cunningtoni (Sharpe, 1855); Kennedy and Juignet, p 174, figs 15c, d; 21c; 27c, d.

1994. Cunningtoniceras cunningtoni (Sharpe, 1855); Kennedy, p. 226.

1998. Cunningtoniceras cunningtoni (Sharpe, 1855); Kaplan et al., p. 146, pl. 56, fig. 5; pl. 57.

1999. Cunningtoniceras cunningtoni (Sharp, 1855) [sic]; Hayakawa and Nishino, p. 8, pl. 11a, g; pl. 12, a-c.

2011. Cunningtoniceras cunningtoni (Sharpe, 1855); Mosavina and Wilmsen p. 184, text-figs 6a, b; 7a, b.

2013. Cunningtoniceras cunningtoni (Sharpe); Reboulet et al., text-fig. $4 \mathrm{~b}$.

2014. Cunningtoniceras cunningtoni (Sharpe, 1855); Walaszczyk et al., text-fig. 23c-f.

HOLOTYPE: By monotypy, BMNH 88704, from the Lower Chalk of Upton Scudamore, Wiltshire, England, the original of Sharpe 1855, p. 35, pl. 15, fig. 2, refigured by Wright and Kennedy 1987, text-figs 76, 77.

MATERIAL: UW1962, 1124 and 1962, from bed M3 of the Mahaboboka section.

DESCRIPTION: UW1962 (Pl. 8, Figs 5, 6) is a wellpreserved individual $55.3 \mathrm{~mm}$ in diameter, retaining its original aragonitic shell. Coiling is evolute, the umbilicus comprising an estimated $20-25 \%$ of the diameter, deep, with a feebly convex umbilical wall and broadly rounded umbilical shoulder. The intercostal whorl section is depressed, rounded-rectangular, with the greatest breadth around mid-flank. The costal whorl section is very depressed, polygonal, with the greatest breadth at the inner ventrolateral horn, the costal whorl breadth to height ratio 1.7. There are eight primary ribs on the adapertural half whorl. They arise at the umbilical seam, and are weak on the umbilical wall, developing into bullae of variable strength, perched on the umbilical shoulder. The bullae give rise to a broad, straight prorsiradiate rib, differentiated into a pair of riblets that loop to a prominent inner ventrolateral horn, directed outwards and slightly upwards. A broad, low rib connects to a strong outer ventrolateral clavus. A pair of ribs link the clavi across the venter. Each bears a rounded to feebly bullate siphonal tubercle. A single coarse ventral rib, with a similar siphonal tubercle separates successive primary rib groups. UW1124 (P1. 8, Figs 1-4), in similar preservation, has inner whorls preserved to a diameter of $53 \mathrm{~mm}$ with comparable ornament, and 16 ribs per whorl. A further outer whorl fragment extends the specimen to a diameter of 72 $\mathrm{mm}$. The umbilical seam is notched to accommodate the inner ventrolateral horns of the previous whorl. These have become spatulate at the greatest preserved diameter, with a distinct doso-ventral flattening. The basic pattern of ventrolateral ornament persists, but the venter has become broadly convex, and the outer ventrolateral and siphonal tubercles subdued.

DISCUSSION: Cunningtoniceras cunningtoni is interpreted very broadly here, following Wright and Kennedy (1987) (who discuss differences between cunningtoni and other species referred to the genus) and Mosavina and Wilmsen (2011), incorporating a number of the subspecies recognized by Zaborski (1985) and Howarth (1985).

OCCURRENCE: Cunningtoniceras cunningtoni characterizes the lower Middle Cenomanian, first appearing in a Cunningtoniceras inerme Zone (regarded by some authors as a Subzone of a broad Acanthoceras rhotomagense Zone). There are records from southern England, Sarthe and Provence in France, Germany, Switzerland, Turkmenistan, Iran, Algeria, Morocco, Nigeria, Angola, Madagascar, southern India, Japan, New Guinea, Bathurst Island (northern Australia), and Colorado in the United States.

Suborder Ancyloceratina Wiedmann, 1966

Superfamily Turrilitoidea Gill, 1871

Family Turrilitidae Gill, 1871

Genus and subgenus Mariella Nowak, 1916 


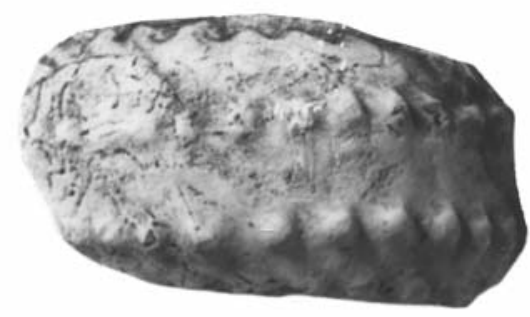

A

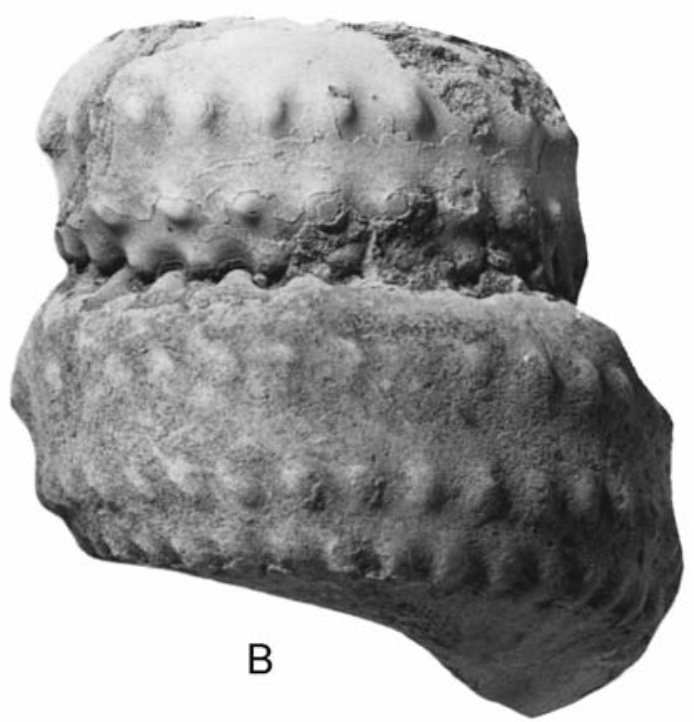

Text-fig. 7. Mariella (Mariella) stolizcai (Collignon, 1964). A - UW1073, from Berekata-A, Lower Cenomanian Mantelliceras dixoni Zone. B - the original of Collignon, 1964, p. 49, pl. 330, fig. 1476, from Collignon's locality 474, Ouest Beraketa sur Sakondry (Manera), housed in the collections of the Université de Bourgogne, Dijon. Figures are $\times 1$

TYPE SPECIES: Turrilites bergeri Brongniart, 1822 p. 395 , pl. 7, fig. 3 , by original designation by Nowak 1916 p. 10.

\section{Mariella (Mariella) stolizcai (Collignon, 1964)} (Text-fig. 7)

1866. Turrilites Bergeri Brongniart; Stoliczka, p. 185 (pars), pl. 86, fig. 6 only.

1964. Plesioturrilites stolizcai Collignon, p. 49, pl. 330, fig. 1476.

TYPE: Collignon (1964, p. 49) introduced stolizcai as nomen novum for Turrilites Bergeri Brongniart; Stoliczka, 1866, p. 185, pl. 86, fig. 6, a specimen from the Utatur Group between Odium and Moraviatoor, which is the holotype by monotypy.

\section{MATERIAL: UW1073, from locality A, Berekata.}

DESCRIPTION AND DISCUSSION: The specimen is a fragment of body chamber with a maximum preserved whorl height of $26.5 \mathrm{~mm}$. The junction of the upper and outer whorl faces is markedly crenulated to accommodate the lowest row of tubercles of the preceding whorl. The upper part of the outer whorl face is broadly convex. The middle part is flattened, the junction of outer and lower whorl faces narrowly rounded, the lower whorl face concave. There are three rows of tubercles, the tubercles in the rows equal in number, with 12 preserved on the fragment. The tubercles in the upper row are rounded to obliquely elongated. A broad smooth zone separates them from the tubercles in the second row, which are displaced adaperturally and slightly spirally elongated. The tubercles in the third row are close to those in the second row, are obliquely elongated, and displaced adaperturally. The relative positions of the three rows of tubercles, notably the wide separation of those in the first two, matches that in the Madagascan example figured by Collignon in 1964, and reproduced here as Text-fig. 6B. The presence of three rather than four rows of tubercles separates the species from Mariella (M.) bergeri (Brongniart, 1822) (p. 395, pl. 7, fig. 3; see revision in Atabekian 1985 and Kennedy and Latil 2007).

OCCURRENCE: Lower Cenomanian of South India and Madagascar.

Genus Hypoturrilites Dubourdieu, 1953

TYPE SPECIES: Turrilites gravesianus d'Orbigny 1842 , p. 596 , pl. 144 , figs $3-5$, by the original designation of Dubourdieu 1953, p. 44.

Hypoturrilites taxyfabreae (Collignon, 1964)

(Pl. 9, Figs 6-14)

1964. Plesioturrilites taxy-fabreae Collignon p. 50, pl. 330, fig. 1480. 
2014. Hypoturrilites taxyfabreae Collignon, 1964; Walaszczyk et al., text-fig. 24e.

TYPE: The holotype, by original designation, is the original of Collignon 1964 p. 50, pl. 330, fig. 1480, from his gisement 474, east of Beraketa-sur-Sakondry (Manera), Madagascar, reillustrated here as pl. 9, fig. 4.

MATERIAL: UW1063, from Berekata-A. UW1267 and 1518, from Berekata. UW1289, 1290, UW1307, 1320, from bed 11; UW0807, from beds 13-14; UW1322, from bed 14; UW0832 and 1530 from bed 21 of the Vohipaly section; UW1525 and 1964 from bed M3 of the Mahaboboka section.

DESCRIPTION: Specimens comprise up to five whorls, with whorl heights of 4.3-28 $\mathrm{mm}$. The smallest specimens referred to the species are all embedded in matrix. The outer whorl face is convex, with an upper row of large, rounded tubercles that are the bases of septate spines, preserved in UW1267 (Pl. 9, Fig. 10), there are two rows of smaller, more numerous tubercles below, spaced close together, the lower row the bases of spatulate septate spines, better seen in UW1063 (P1. 9, Fig. 12) and UW1260 (Pl. 9, Fig. 11). UW1964 (P1. 9, Figs 5, 6) has the larger tubercles in the upper row elongated normal to the inter-whorl suture, the tubercles in the lower two rows twice as numerous as the larger tubercles in the upper row. A strong radial rib extends from the lowest row of tubercles across the lower whorl face (Pl. 9, Fig. 5). UW132 (Pl. 9, Figs 7, 8) and UW1270 (Pl. 9, Fig. 9) both have three rows of tubercles, but when compared to the previous specimens, those in the upper row are much larger and fewer than those of the holotype (P1. 9, Fig. 4) at the same size. They are provisionally treated as an intraspecific variant here.

OCCURRENCE: Upper Lower and lower Middle Cenomanian of Madagascar.

Genus Turrilites Lamarck, 1801

TYPE SPECIES: Turrilites costatus Lamarck, 1801, p. 102, by the original designation of Lamarck 1801, p. 102 .

Turrilites scheuchzerianus Bosc, 1801 (P1. 9, Figs 1-3)

1708. Turbinites Langius, p. 112, fig. 6.
1801. Turrilites scheuchzerianus Bosc; in Buffon, p. 190 (copy of Langius).

1994. Turrilites (Turrilites) scheuchzerianus Bosc, 1801; Kennedy, p. 232, pl. 11, fig. 4.

1996. Turrilites scheuchzerianus Bosc, 1801; Wright and Kennedy, p. 349, pl. 106, figs. 7, 8, 11, 12; pl. 107, figs 1-7; text-figs 137g, j; 138c, d, f, g, h, i, n; 139d-i; 140a, d, e, f, g, h, i; 143h; 147a, b (with full synonymy).

1997. Turrilites (Turrilites) scheuchzerianus Bosc, 1801; Wilmsen, pl. 1, fig. 3.

1998. Turrilites scheuchzerianus Bosc; Kaplan et al., p. 213, pl. 59, figs 12-14; pl. 64, figs 4, 7, 10, 11; pl. 65, figs $1-3,6)$.

1999. Turrilites scheuchzerianus Bosc; Hayakawa and Nishino, p. 11, pl. 10, figs a, b, c, e, f.

2013. Turrilites scheuchzerianus Bosc; Reboulet et al., textfig. $5 \mathrm{c}$.

2014. Turilites scheuchzerianus Bosc, 1801; Walaszczyk et al., text-fig. 24c, d.

TYPE: Bosc's figure is a copy of Langius 1708 , pl. 112, fig. 6. The status and whereabouts of the type material of this species has not been established.

MATERIAL: UW0837, 1297, 1304, 1306, 1311, 1318, 1891 , from bed 23 of the Vohipaly section.

DESCRIPTION AND DISCUSSION: The material consists of a series of body chamber fragments. The most complete is UW1311 (Pl. 9, Fig. 3), 1.5 whorls with a maximum preserved whorl height of $28 \mathrm{~mm}$. The upper whorl face is concave and smooth. The junction of upper and outer whorl faces is sharp. The outer whorl faces is broadly convex. The lower whorl face is feebly convex. There are 18 ribs per whorl. They are coarse, concave and oblique on the outer whorl face, sweeping forwards and convex across the junction of outer and lower whorl faces, and weakening and effacing across the lower whorl face. Turrilites scheuchzerianus is one of the most distinctive of the Cenomanian Turrilitidae; the coarse entire ribs of the later growth stages and lack of tubercles are immediately distinctive.

OCCURRENCE: Upper Lower Cenomanian Mantelliceras dixoni Zone, and Middle Cenomanian. There are also records from England, France, Germany, Bornholm in the Baltic, Poland, France, Switzerland, Spain and southern Italy, east to Kazakhstan and Turkmenistan in Central Asia, Iran, North Africa, the Middle East, Nigeria, KwaZulu-Natal in South Africa, Madagascar, Tibet, Japan, the U.S. Gulf Coast and Western Interior. 
Family Baculitidae Gill, 1871

Genus Sciponoceras Hyatt, 1894

TYPE SPECIES: Hamites baculoides Mantell, 1822, p. 123, pl. 23, figs 6, 7, by original designation by Hyatt 1894, p. 578.

Sciponoceras antanimangaensis (Collignon, 1964)

(P1. 10, Figs 1-11; Text-fig. 8A-H)

1866. Baculites gaudini Pictet; Stoliczka, p. 199 (pars), pl. 91, figs 7, 8, non 10 .

1964. Lechites antanimangaensis Collignon, p. 34, pl. 325, fig. 1451 .

1995. Sciponoceras [Lechites] antanimangaense (Collignon, 1964); Wright and Kennedy, p. 317, text-fig.132p, q.

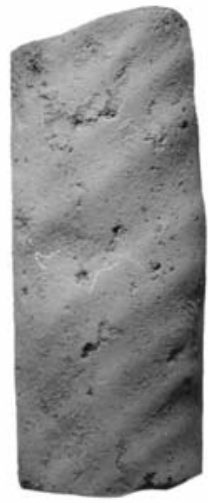

A

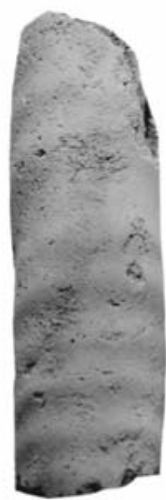

B

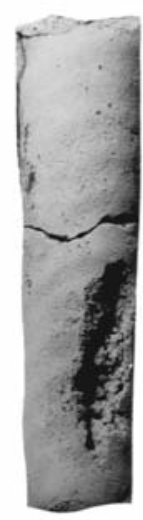

G

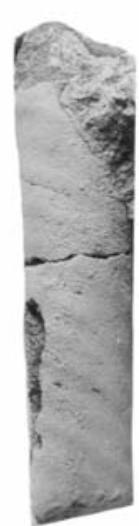

$\mathrm{H}$

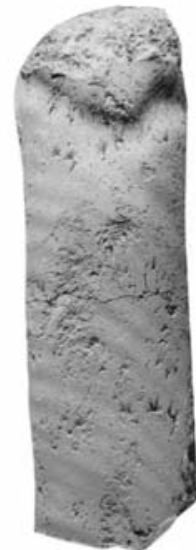

I

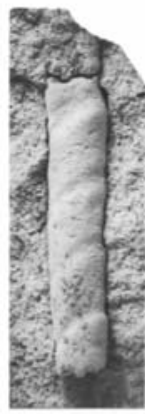

C
2001. Lechites antanimangaensis (Collignon, 1964); Klinger and Kennedy, p. 241, text-fig. 170M, N.

2001. Lechites sp. Klinger and Kennedy, p. text-fig. 174.

TYPE: The holotype, by original designation, is the original of Collignon 1964 p. 34, pl. 325, fig. 1451, from the Lower Cenomanian of his gisement 362, Signal Antanimananga I (Mandabe), Madagascar, in the collections of the Université de Bourgogne, Dijon, and illustrated here as P1. 10, Figs 10, 11.

MATERIAL: UW0788, 0843, 0845, 0848, 0856, 0857, 0863, 1249, 1522 from bed 21; UW1891 and 1321 from bed 23 of the Vohipaly section.

DESCRIPTION: The earliest growth stage seen is UW0848, a $27 \mathrm{~mm}$ long phragmocone fragment with

Text-fig. 8. A-H - Sciponoceras antanimangaensis (Collignon, 1964). A, B - UW1321, from bed 23; C - UW0848, D-F - UW0799, G, H - UW0856, all from bed 21, of the Vohipaly section. I-L - Sciponoceras cucullatum Collignon, 1964, UW1288, from bed 23 of the Vohipaly section. K, L-the holotype, the original of Collignon, 1964, p. 38, pl. 326, fig. 1458, from Collignon's locality 505, Ouest des chutes de la Mahaboboka (Manera), housed in the collections of the Université de Bourgogne, Dijon. Figures A-C, G-L are x1; figures D-F are $\times 2$ 
a maximum preserved whorl height of $5.6 \mathrm{~mm}$ (Textfig. 8C). There are four strong constrictions on the fragment, straight and prorsiradiate on the inner to middle flank, they broaden and deepen on the outer flank and ventrolateral margin, flexing back, and feebly concave, to cross the venter in a broad convexity. UW0799 (Text-fig. 8D-F) is a $25.5 \mathrm{~mm}$ long body chamber fragment with a maximum preserved whorl height of $9.5 \mathrm{~mm}$, and a whorl breadth to height ratio of 0.85 , the whorl section subcircular. There is a single well-developed constriction at the adapical end of the fragment, and a weaker incipient constriction towards the adapertural end. The constriction is effaced at mid-dorsum, but deeply incised and concave on the dorsolateral margin, deep and prorsiradiate on the flanks, and crosses the venter in a broad convexity. Very faint ornament is present, with strongly prorsiradiate ribs visible on the flanks, strengthening and feebly convex on the outer flank and ventrolateral shoulder, and crossing the venter in a broad convexity; the rib index is 5 . The remaining specimens are all body chamber fragments, with whorl heights of 11 to $27 \mathrm{~mm}$, the whorl section varying from circular to subcircular, with a whorl breadth to height ratio of 0.86 . Ornament varies from weak (P1. 10, figs 2, 3) to strong (Pl. 10, Figs 1, 6, 7-9). The rib index is 3 or 4, the ribs weak and feebly concave on the dorsum, sweeping forwards and strengthening across the dorsolateral margin, and strong, straight and prorsiradiate across the flanks, where they are separated by wider interspaces. They flex back and are feebly convex on the outer flanks and ventrolateral shoulders of some specimens (P1. 10, Fig. 9) and may broaden and develop a flattened, ribbon-like morphology (Pl. 10, Fig. 1). The ribs cross the venter in a broad convexity.

DISCUSSION: The form of the constrictions, coarse and distant ribs separate the present species from cooccurring Sciponoceras cucullatum, described below. There are strong similarities between large individuals of the present species and large individuals of both Sciponoceras gracile (Shumard, 1860) and Sciponoceras kossmati (Nowak, 1908) as figured by Klinger and Kennedy (2001, text-figs 186, 187, 188a-c), but both of these species are immediately distinguished by their much higher rib density.

Stoliczka (1866, pl. 91, figs 7, 8) figured two large body chambers of a Sciponoceras from the Utatur Group near Odium in Tamil Nadu, South India, referring them to gaudini of Pictet. Their size and ornament is that of the present species; the only difference is the more compressed whorl section of Stoliczka's pl. 91, fig. $8 \mathrm{a}$.
OCCURRENCE: Lower Cenomanian of Madagascar and South India, the latter dating based on the unpublished observations of Professor A.S. Gale.

\section{Sciponoceras cucullatum Collignon, 1964 (Text-figs 8I-L)}

1903. Baculites? Choffat, p. 16, pl. 1, figs 7, 8.

?1936. Baculites Gaudini Pictet and Campiche; Venzo p. 118 (60), pl. 10 (6), fig. 3.

1964. Sciponoceras cucullatum Collignon, p. 38, pl. 326, fig. 1458.

1995. Sciponoceras cucullatum Collignon, 1964; Wright and Kennedy, p. 317, text-fig. $132 \mathrm{~g}-\mathrm{k}$.

1997. Sciponoceras cucullatum Collignon, 1964; Klinger and Kennedy, p. 12, text-figs 2g-1, n-o; 4; 5; 6a-d.

2001. Sciponoceras cucullatum Collignon, 1964; Klinger and Kennedy, p. 258.

TYPE: The holotype, by original designation, is the original of Collignon 1964, p. 38, pl. 326, fig. 1458, from the Lower Cenomanian of his gisement 505, west of the chutes de la Mahababoka (Manera), Madagascar, illustrated here as Text-fig. $8 \mathrm{~K}$, L. It is housed in the collections of the Université de Bourgogne, Dijon.

MATERIAL: UW1288, from bed VH23 of the Vohipaly section. UW1506, from the Berekata section.

DESCRIPTION: UW1288 (Text-fig. 8I-J) is a phragmocone fragment $57 \mathrm{~mm}$ long, with a maximum preserved whorl height of $17.8 \mathrm{~mm}$ and a whorl breadth to height ratio of 0.78 , the whorl section slightly ovoid, the venter more narrowly rounded than the dorsum. The surface of the internal mould is ornamented by crowded delicate ribs; the rib index is 7 . The ribs are concave and very weak to effaced on the dorsum, sweeping forwards, strongly prorsirdiate and straight on the inner flanks, strengthening progressively, and feebly convex on the outer flanks and crossing the venter in a broad convexity. There is a strong constriction at the adapertural end of the fragment. It is produced into a linguoid peak on the dorsum, strengthens and deepens into an asymmetric $\mathrm{V}$ with a rounded termination on the flank, and crosses the venter in a broad convexity. The incompletely exposed suture has moderately incised saddles and lobes, the former with narrow stems.

UW 1506 is a worn $85 \mathrm{~mm}$ long fragment with a maximum preserved whorl height of $32.2 \mathrm{~mm}$, and a whorl breadth to height of 0.88 . The style and density of ornament on the fragment is as in the previous specimen, with a rib index of 8 . 
DISCUSSION: The higher rib density and distinctive course of the constrictions immediately distinguish these specimens from co-occuring Sciponoceras antanimangaensis. On the basis of the present material it may be that the holotype (Text-fig. $8 \mathrm{~K}, \mathrm{~L}$ ) is a microconch, and UW1500 a macroconch body chamber. Large baculitids from northern Mozambique referred to Baculites? by Choffat (1903 pl. 1, figs 7, 8) have a maximum preserved whorl height of $35 \mathrm{~mm}$, a slightly compressed whorl section, and a comparable style of ornament to that of the present material and that described from northern KwaZulu-Natal, South Africa by Klinger and Kennedy (1997). They have a rib index of 7-8, and are interpreted as large, presumably macroconch individuals of the present species.

OCCURRENCE: Lower Cenomanian of Madagascar, Lower or Middle Cenomanian of northern KwaZuluNatal, South Africa, imprecisely dated within the Upper Albian to Cenomanian of northern Mozambique.

\section{Achnowledgements}

We acknowledge the insightful review by Herbert Klinger. Kennedy acknowledges the technical support of the staff of the Geological Collections, Oxford University Museum of Natural History, and the Department of Earth Sciences, Oxford. The financial assistance of Institute of Geology of the Faculty of Geology in Warsaw is acknowledged. The project was financed by Polish Ministry of Science, grant number: 2 O04D 03828.

\section{REFERENCES}

Aly, F., Abdel-Gawad and Gabir, M.A. 2005. Uppermost Albian-basal Cenomanian ammonites from North Sinaia, Egypt. Egyptian Journal of Palaeontology, 5, 347-385.

Amédro, F., Cobban, W.A., Breton, G. and Rogron, P. 2002. Metengonoceras teigenense Cobban et Kennedy, 1989: une ammonite exotique d'origine Nord-Américaine dans le Cénomanien inférieur de Basse-Normandie (France). Bulletin Trimestrielle de la Société Géologique de Normandie et Amis du Muséum du Havre, 87, 5-25. [for 2000]

Atabekian, AA. 1985. Turrilitids of the late Albian and Cenomanian of the southern part of the USSR. Trudy Mezhvedomstvennogo Stratigraficheskogo Komiteta SSSR, 14, 112 pp. [In Russian]

Besairie, H. and Collignon, M. 1960. Lexique Stratigraphique International, 4, 2, Madagascar (supplément), 1-190.

Böhm, J. 1895. Review of A. de Grossouvre: Recherches sur la craie supérieure. 2nd part. Neues Jahrbuch für Mineralogie, Geologie und Paläontologie, 1895, 360-366.
Bosc, L.A.G. 1801. (An. 13). In Roissy, F. Histoire Naturelle générale et particulière, des Mollusques, Animaux sans vertebrès et à sang blanc. Ouevrage faisant suit aux Oeuvres de Leclerc de Buffon, et partie du Cours complet d'Histoire naturelle, rédigé par C.S. Sonnini, membre de plusiers Sociétés savants. Continué par. F. de Roissy. viii $+448+3$ p. Déterville; Paris.

Breistroffer, M. 1947. Sur les zones d'ammonites dans l'Albien de France et d'Angleterre. Travaux du Laboratoire de Géologie de l'Université de Grenoble, 26, 17-104. [1-88 in separates]

Brongniart, A. 1822. Sur quelques terrains de Craie hors du Bassin de Paris, 80-101. In: Cuvier, G. and Brongniart, A. Description géologique des environs de Paris, 3rd edn. 428 pp. Dufour and d'Ocagne; Paris.

Choffat, P. 1903. Contributions à la connaissance géologique des colonies portugaises d'Afrique. I, le Crétacique de Conducia. Commission du Service Géologique de Portugal, 32 pp.

Collignon, M. 1931. Paléontologie de Madagascar, XVI. La faune du Cénomanien à fossiles pyriteux du nord de Madagascar. Annales de Paléontologie, 20, 43-104 (1-64).

Collignon, M. 1937. Ammonites Cénomaniennes du sudouest de Madagascar. Annales géologiques du Service des Mines de Madagascar, 8, 29-72.

Collignon, M. 1961. Ammonites néocrétacées du Menabe (Madagascar). VII, Les Desmoceratidae. Annales Géologiques du Service des Mines de Madagascar, 31, 115 pp.

Collignon, M. 1964. Atlas des fossiles caracteristiques de Madagascar (Ammonites), XI Cenomanien: xi + 152 pp. Service Géologique; Tananarive.

Coquand, H. 1862. Géologie et paléontologie de la région de la Province de Constantine. Mémoires de la Société d'Émulation de la Provence, 2, 1-341.

Delamette, M. and Kennedy, W.J. 1991. Cenomanian ammonites from the condensed deposits of the Helvetic Domain. Journal of Paleontology, 65, 435-465.

Diener, C. 1925. Ammonoidea neocretacea. Fossilium Catalogus (1: Animalia), 29, 244 pp.

Dixon, F. 1850. The Geology and Fossils of the Tertiary and Cretaceous Formations of Sussex. 1st Edn., xxxii +423 pp. W.J. Smith; Brighton.

Dubourdieu, G. 1953. Ammonites nouvelles des Monts du Mellègue. Bulletin du Service de la Carte Géologique de l'Algerie. 1e série, Paléontologie, 16, 76 pp.

Gale, A.S., Bown, P., Caron, M., Crampton, J., Crowhurst, S. J., Kennedy, W.J., Petrizzo, M.R. and Wray, D.S. 2011. The uppermost Middle and Uppper Albian succession at the Col de Palluel, Hautes-Alpes, France: an integrated study (ammonites, inoceramid bivalves, planktonic foraminifera, nannofossils, geochemistry, stable oxygen and carbon isotopes, cyclostratigraphy). Cretaceous Research, 37, 59-130. 
Gauthier, H. 2006. Révision Critique de la Paléontologie Française d'Alcide d'Orbigny, 6, Céphalopodes Crétacés. 1-292 +1-662. Backhuys; Leiden.

Gill, T. 1871. Arrangement of the Families of Mollusks. Smithsonian Miscellaneous Collections, 227, xvi + 49 pp.

Grossouvre, A. de 1894. Recherches sur la craie supérieure, 2, Paléontologie. Les ammonites de la craie supérieure. Mémoires du Service de la Carte Géologique détaillée de la France, 1-264 (mislabeled 1893).

Hayakawa, H. and Nishino, T. 1999. Cenomanian ammonite fauna from Nakagawa, Hokkaido, Japan. Bulletin of Nakagawa Museum of Natural History, 2, 1-40.

Hayakawa, H. and Takahashi, T. 2000. Sharpeiceras (Cretaceous acanthoceratid) from Nakagawa, Hokkaido. Bulletin of the Nagakawa Museum of Natural History, 3, 7-14.

Howarth, M.K. 1985. Cenomanian and Turonian ammonites from the Novo Redondo area, Angola. Bulletin of the British Museum (Natural History) Geology, 39, 73105.

Hyatt, A. 1894. Phylogeny of an Acquired Characteristic. Proceedings of the American Philosophical Society, 32, 349647.

Hyatt, A. 1900. Cephalopoda, pp. 502-604. In: Zittel, K.A. von 1896-1900, Textbook of Palaeontology, transl. Eastman, C.R. Macmillan; London and New York.

Hyatt, A.1903. Pseudoceratites of the Cretaceous. United States Geological Survey Monograph, 44, 1-351.

Immel, H. and Seyed-Emami, K. 1985. Die Kreideammoniten des Glaukonitkalkes (O. Alb- O. Cenoman) des Kolah Qazi - Gebirges sudöstlich von Esfahan (Zentral Iran). Zitteliana, 12, 87-137.

Jukes-Browne, A.J. 1896. VI. Critical remarks on some of the fossils. In: Jukes-Browne, A.J. and Hill, W. A delimitation of the Cenomanian: being a comparison of the corresponding beds in southwestern England and northern France. Quarterly Journal of the Geological Society of London, 52, 99-178.

Kaplan, U., Keller, S. and Wiedmann, J. 1984. Ammoniten und Inoceramen - Gliederung des Norddeutschen Cenoman. Schriftenreihe Erdwissenchaftlichte Komission, 7, 307-347.

Kaplan, U., Kennedy, W.J., Lehmann, J., and Marcinowski, R. 1998. Stratigraphie und Ammonitenfaunen des westfälischen Cenoman. Geologie und Paläontologie in Westfalen, 51, 236 pp.

Kawabe, F., Takashima, R., Wani, R., Nishi, H. and Moriya, K. 2003. Upper Albian to Lower Cenomanian biostratigraphy in the Oyubari area, Hokkaido, Japan: towards a Cretaceous biochronology for the North Pacific. Acta Geologica Polonica, 53, 81-91.

Kennedy, W.J. 1971. Cenomanian ammonites from southern England. Special Papers in Palaeontology, 8, v 133 pp. Kennedy, W.J. 1994. Cenomanian ammonites from Cassis,
Bouches-du-Rhône, France. Palaeopelagos, Special Volume, 1, 209-254.

Kennedy, W.J., Amédro, F., Robaszynski, F. and Jagt, J.W.M. 2011. Ammonite faunas from condensed CenomanianTuronian sections ('Tourtias') in southern Belgium and northern France. Netherlands Journal of Geosciences, 90, 209-223.

Kennedy, W.J. and Bilotte, M. 2009. A revision of the cephalopod fauna of the 'niveau rouge' of the Selva de Bonansa, Huesca Province, northern Spain. Bulletin of the Moscow Society of Naturalists, 84, 39-70.

Kennedy, W.J. and Juignet, P. 1993. A revision of the ammonite faunas of the type Cenomanian. 4. Acanthoceratinae (Acompsoceras, Acanthoceras, Protacanthoceras, Cunningtoniceras and Thomelites). Cretaceous Research, 14, 145-190.

Kennedy, W.J., Juignet, P. and Wright, C.W. 1986. A revision of the ammonite fauna of the type Cenomanian. 3. Mantelliceratinae. Cretaceous Research, 7, 19-62.

Kennedy, W.J. and Latil, J.-L. 2007. The Upper Albian ammonite succession in the Montlaux section, Hautes-Alpes, France. Acta Geologica Polonica, 57, 453-478.

Kennedy, W. J. and Wright, C.W. 1985. Mrhiliceras gen. nov. (Cretaceous Ammonoidea), a new Cenomanian mantellicerine. Neues Jahrbuch für Geologie und Paläontologie Monatshefte, 1985, 513-526.

Klinger, H.C. and Kennedy, W.J. 1997. Cretaceous faunas from Zululand and Natal, South Africa. The ammonite family Baculitidae Gill, 1871 (Excluding the genus Eubaculites). Annals of the South African Museum, 105, 1206.

Klinger, H.C. and Kennedy, W.J. 2001. Stratigraphic and geographic distribution, phylogenetic trends and general comments on the ammonite family Baculitidae Gill, 1871 (with an annotated list of species referred to the family). Annals of the South African Museum, 107, 1-290.

Korn, D., Ebbighausen, V., Bockwinkel J. and Klug, C. 2003. The A-mode ontogeny in prolecanitid ammonites. Palaeontology, 46, 1123-1132.

Kossmat, F. 1895-1898. Untersuchungen über die Sudindische Kreideformation. Beiträge zur Paläontologie Österreich-Ungarens und des Orients, 9 (1895), 97-203 (1107); 11 (1897), 1-46 (108-153); 11(1898), 89-152 (154-217).

Kullmann, J. and Wiedmann, J. 1970. Significance of sutures in phylogeny of Ammonoidea. University of Kansas, $\mathrm{Pa}$ leontological Contributions, 42, 1-32.

Lamarck, J.P.B.A. de M. de 1801. Système des Animaux sans vertebrès. vii $+432 \mathrm{pp}$. The author; Deterville, Paris.

Langius C.N. [Lang K.] 1708. Historia lapidum figuratorum Helvetiae. 165 pp. Haeredes Gottofredi Hautt and Joannem Jodocum Halter; Lucerne.

Lewy, Z. and Raab, M. 1978. Mid-Cretaceous stratigraphy of 
the Middle East. Annales du Muséum d'Histoire Naturelle de Nice, 4 (for 1976), XXXII, 14 pp.

Mantell, G.A. 1822. The fossils of the South Downs; or illustrations of the geology of Sussex. xvi +327 pp. Lupton Relfe; London.

Marcinowski, R. and Wiedmann, J. 1990. The Albian ammonites of Poland. Palaeontologica Polonica, 50, 94 pp.

Matheron, P. 1842. Catalogue méthodique et descriptif des corps organisés fossiles du département des Bouches-duRhône et lieux circonvoisins. Répetoire des travaux de la Société de Statistique de Marseille, 6, 269 pp.

Matsumoto, T. 1987. Note on Pachydesmoceras, a Cretaceous ammonite genus. Proceedings of the Japan Academy, series B, 63, 5-8.

Matsumoto, T. 1988. A monograph of the Puzosiidae (Ammonoidea) from the Cretaceous of Hokkaido. Palaeontological Society of Japan Special Papers, 30, 1-179.

Matsumoto, T., Hayakawa, H. and Toshimitsu, S. 1999. An ammonite species of Sharpeiceras from Madagascar. Bulletin of the Mikasa City Museum, 3, 17-21.

Matsumoto, T. and Kawashita, Y. 1998. Two ammonite species of the genus Sharpeiceras from the Cretaceous of Hokkaido. Paleontological Research, 2, 89-95.

Matsumoto, T. and Nishida, T. 2002. A study of Mrhiliceras (Cretaceous Ammonoidea). Proceedings of the Japan Academy, series B, 78, 185-189.

Matsumoto, T. and Toshimitsu, S. 1998. On some species of Sharpeiceras (Ammonoidea) from the Cretaceous of Hokkaido. Bulletin of the Geological Survey of Japan, 49, 621-631.

Matsumoto, T. and Toshimitsu, S. 2005. Additional notes on some species of Mantelliceras (Ammonoidea) from Central Hokkaido, North Japan. Bulletin of the Geological Survey of Japan, 56, 31-36.

Michelin, H. 1838. Note sur une argile dépendant du Gault, observée au Gaty, commune de Gérodot, département de l'Aube. Mémoires de la Société Géologique de France, (1), 3, 97-103.

Mosavina, A. and Wilmsen, M. 2011. Cenomanian Acanthoceratoidea (Cretaceous Ammonoidea) from the Koppeh Dagh, NE Iran: taxonomy and stratigraphic implications. Acta Geologica Polonica 61, 175-192.

Neumayr, M. 1875. Die Ammoniten der Kreide und die systematik der Ammonitiden. Zeitschrift der Deutschen Geologischen Gesellschaft, 27, 854-942.

Nishida, T., Matsumoto, T., Yokoi, K., Kawashita, Y., Kyuma, Y., Egashira, N., Aizawa, J., Maiya, S., Ikuji, Y. and Yao, A. 1996. Biostratigraphy of the Cretaceous Middle Yezo Group in the Soeushinai area of Hokkaido-with special reference to the transitional part from the Lower to Upper Cretaceous. Journal of the Faculty of Education, Saga University, 44, 65-149. [In Japanese with English abstract]
Nowak, J. 1908. Untersuchungen über Cephalopoden der Oberen Kreide in Polen. I. Teil, Genus Baculites. Bulletin International de l'Academie des Sciences de Cracovie Classe des Sciences Mathématiques et Naturelles, Série B: Sciences Naturelles for 1908, 326-353.

Nowak, J. 1916. Über die bifiden Loben der oberkretazischen Ammoniten und ihre Bedeutung für die Systematik. Bulletin International de l'Académie des Sciences de Cracovie. Classe des Sciences Mathématiques et Naturelles, Série B: Sciences Naturelles for 1915, 1-13.

Orbigny, A. d'. 1840-1842. Paléontologie française: Terrains crétacés. 1. Céphalopodes. 1-120 (1840); 121-430 (1841); 431-662 (1842). Masson; Paris.

Passy, A. 1832. Description géologique du département de la Seine-inférieure. xvi +371 pp. Nicétas Periaux; Rouen.

Pervinquière, L. 1903. Étude géologique de la Tunisie centrale. Carte Géologique de la Tunisie, viii + 359 pp. de Rudeval; Paris.

Pervinquière, L. 1907. Études de paléontologie tunisienne. 1. Céphalopodes des terrains secondaires. Carte Géologique de la Tunisie, $v+438 p p$.

Pictet, F. J. and Campiche, G. 1858-1864. Description des fossiles du terrain crétacé des environs de Saint-Croix part 2 (1). Description des fossiles. Matériaux pour la Paléontologie Suisse (2) part 1, 1-380; part 2, 1-752.

Reboulet, S., Giraud, F., Colombié, C. and Carpentier, A. 2013. Integrated stratigraphy of the Lower and Middle Cenomanian in a Tethyan section (Blieux, southeast France) and correlations with the Boreal basins. Cretaceous Research, 40, 170-189.

Robaszynski, F., Caron, M., Amédro, F., Dupuis, C., Hardenbol, J. Gonzáles Donoso, J.M., Linares, D. and Gartner, S. 1994. Le Cénomanien de la région de Kalaat Senan (Tunisie Centrale). Révue de Paléobiologie, 12, 351-505.

Schlüter, C. 1871-1876. Cephalopoden der oberen deutschen Kreide. Palaeontographica, 21, 1-24, (1871); 21, 25120(1872); 24, 1-144 (121-264) + x(1876).

Sharpe, D. 1853-57. Description of the fossil remains of Mollusca found in the Chalk of England. I, Cephalopoda. Palaeontographical Society Monographs. 68 pp. 1-26 (1853); 27-36 (1855); 37-68 (1857).

Shumard, B.F. 1860. Observations upon the Cretaceous strata of Texas. Transactions of the Academy of Sciences of St. Louis, 1, 582-590.

Sornay, J. 1965. La faune d'inocérames du Cénomanien et du Turonien du Sud-Ouest de Madagascar. Annales de Paléontologie, Invertebrès, 51, 1-18.

Sowerby, J. 1812-1822. The Mineral Conchology of Great Britain. 1, pls 1-9 (1812), pls 10-44 (1813, pls 45-78 (1814), pls 79-102 (1815); 2, pls 103-14 (1815), pls 115-50 (1816), pls 151-86 (1817), pls 187-203 (1818); 3, pls 204-21 (1818), pls 222-53 (1819), pls 254-71 
(1820), pls 272-306 (1821); 4, pls 307-18 (1821), pls 319-83 (1822). The Author; London,

Spath, L.F. 1922 On the Senonian ammonite fauna of Pondoland. Transactions of the Royal Society of South Africa, 10, 113-147.

Spath, L.F. 1925. On Upper Albian Ammonoidea from Portuguese East Africa, with an appendix on Upper Cretaceous ammonites from Maputoland. Annals of the Transvaal Museum, 11, 179-200.

Spath, L.F. 1926a. On new ammonites from the English Chalk. Geological Magazine, 63, 77-83.

Spath, L.F. 1926b. On the zones of the Cenomanian and the uppermost Albian. Proceedings of the Geologists' Association, 37, 420-432.

Stoliczka, F. 1863-1866. The fossil cephalopoda of the Cretaceous rocks of southern India. Ammonitidae with revision of the Nautilidae etc. Memoirs of the Geological Survey of India. (1), Palaeontologica Indica, 3, (1), 4156(1863); (2-5), 57-106(1864); (6-9), 107-154(1865); (10-13), 155-216(1866).

Szives, O. 2007. Albian Stage. Geologica Hungarica, 57, $75-122$.

Thomel, G. 1972. Les Acanthoceratidae Cénomaniens des châines subalpines méridionales. Mémoires de la Société Géologique de France, (N.S.), 116, 204 pp.

Thomel, G. 1992. Ammonites du Cénomanien et du Turonien du Sud-Est de la France. 1, 1-422; 2, 1-383. Editions Serre; Nice.

Venzo, S. 1936. Cefalopodi del Cretaceo medio-superiore dello Zululand. Palaeontographia Italica, 36, 59-133 (1-75).

Walaszczyk, I., Kennedy, W.J., Dembicz, K., Gale, A.S., Praszkier, T., Rasoamiaramanana, A.H. and Randrianaly, H. 2014. Ammonite and inoceramid biostratigraphy and biogeography of the Cenomanian through basal Middle Campanian (Upper Cretaceous) of the Morondava Basin, western Madagascar. Journal of African Earth Sciences 89, 79-132.

Wiedmann, J. 1966. Stammesgeschichte und System der posttriadischen Ammonoideen; ein Überblick. Neues Jahrbuch für Geologie und Paläontologie Abhandlungen, 125, 49-79; 127, 13-81.
Wiedmann, J. and Dieni, I. 1968. Die Kreide Sardiniens und ihre Cephalopoden. Palaeontographia Italica, 64, 1-171.

Wiedmann, J. and Schneider, H.L. 1979. Cephalopoden und Alter der Cenoman-Transgression von Mülheim-Broich, SW-Westfalen. In: Wiedmann, J. (Ed.), Aspekte der Kreide Europas, International Union of Geological Sciences (A), 6, 645-680.

Wilmsen, M. 1997. Some notes on the Cenomanian cephalopod fauna of the North Cantabrian Basin. Freiberger Forschungsheft, C468, 319-331.

Wilmsen, M., Wood, C. J. Niebuhr, B. and Kaplan, U. 2009. Cenomanian-Coniacian ammonoids of the Danubian Cretaceous Group (Bavaria, southern Germany). Schriftenreihe der Deutschen Gesellschaft für Geowissenschaften, 65, 111-124.

Wright, C.W. 1952. A classification of the Cretaceous Ammonites. Journal of Paleontology, 26, 213-222.

Wright, C.W. and Kennedy, W.J. 1984. The Ammonoidea of the Lower Chalk. Part 1. Palaeontographical Society Monographs, 1-126.

Wright, C.W. and Kennedy, W.J. 1987. The Ammonoidea of the Lower Chalk. Part 2. Palaeontographical Society Monographs, 127-218.

Wright, C.W. and Kennedy, W.J. 1995. The Ammonoidea of the Lower Chalk. Part 4. Palaeontographical Society Monographs, 295-319.

Wright, C.W. and Kennedy, W.J. 1996. The Ammonoidea of the Lower Chalk. Part 5. Palaeontographical Society Monographs, 320-403.

Wright, C.W. and Wright, E.V. 1951. A survey of the fossil Cephalopoda of the Chalk of Great Britain. Palaeontographical Society Monographs, 1-40.

Zaborski, P.M.P. 1985. Upper Cretaceous ammonites from the Calabar region, southeast Nigeria. Bulletin of the British Museum (Natural History) Geology, 39, 1-72.

Zittel, K.A. Von. 1884. Handbuch der Palaeontologie. 1, Abt. 2; Lief 3, Cephalopoda. p. 329-522. R. Oldenbourg; Munich \& Leipzig.

Zittel, K.A. Von. 1895. Grundzüge der Palaeontologie (Palaeozoologie). vii + 972 pp. R. Oldenbourg; Munich \& Leipzig. 


\section{PLATE 1}

1-3 - Calycoceras sp. UW1292; 4, 5, 7-9 - Forbesiceras baylissi Wright and Kennedy, 1984. 4, 5 - UW1828; 7, 8 - UW1496; 9 - UW1262; 6 - Pachydesmoceras kossmati Matsumoto, 1987, UW1262; 10, 11-Forbesiceras largilliertianum (d'Orbigny,1841), UW1520.

The originals of Figs 1-3 are from bed 23 of the Vohipaly section, Lower Cenomanian, Mantelliceras dixoni Zone. The originals of Figs 4, 5, 7, are from bed 3 of the Mahaboboka section, Middle Cenomanian, Cunningtoniceras inerme Zone. The originals of Figs 7, 8, 9, are from the Lower Cenomanian, Mantelliceras dixoni Zone of Berekata. The original of Figs 10, 11, is from beds 13-14 of the Vohipaly section, Lower Cenomanian, Mantelliceras dixoni Zone.

All figures are $\times 1$ 


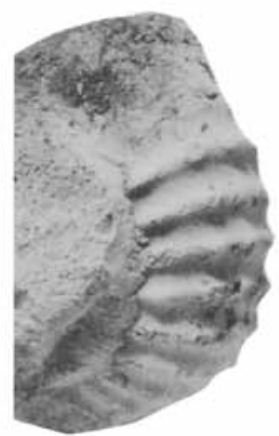

1

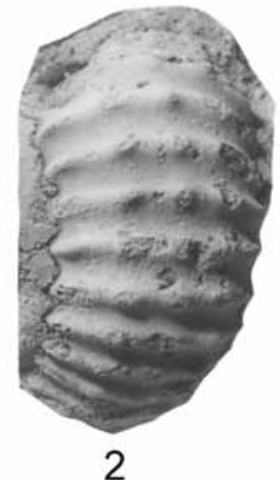

2

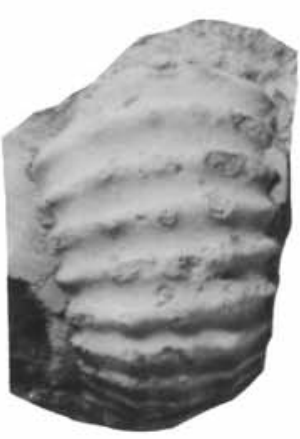

3
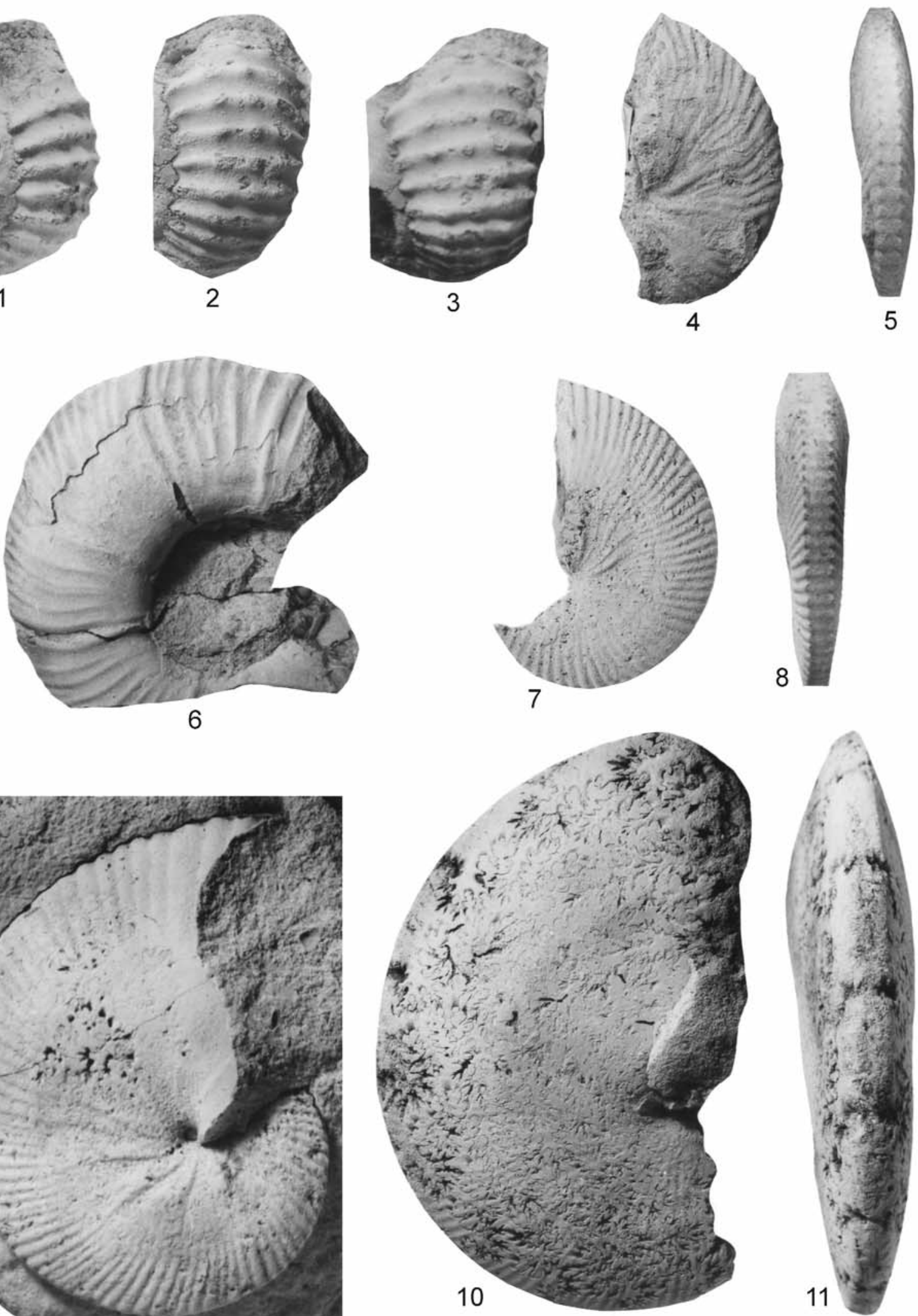


\section{PLATE 2}

Mantelliceras mantelli (J. Sowerby, 1814)

\section{1, 2 - UW1319; 3, 4 - UW0819; 5 - UW0814; 6, 7 - UW1328.}

The originals of $1-3,6,7$, are from bed $11 ; 3,4$, are from bed $23 ; 5$ is from bed 14 of the Vohipaly section, Lower Cenomanian, Mantelliceras dixoni Zone.

All figures are $\times 1$ 

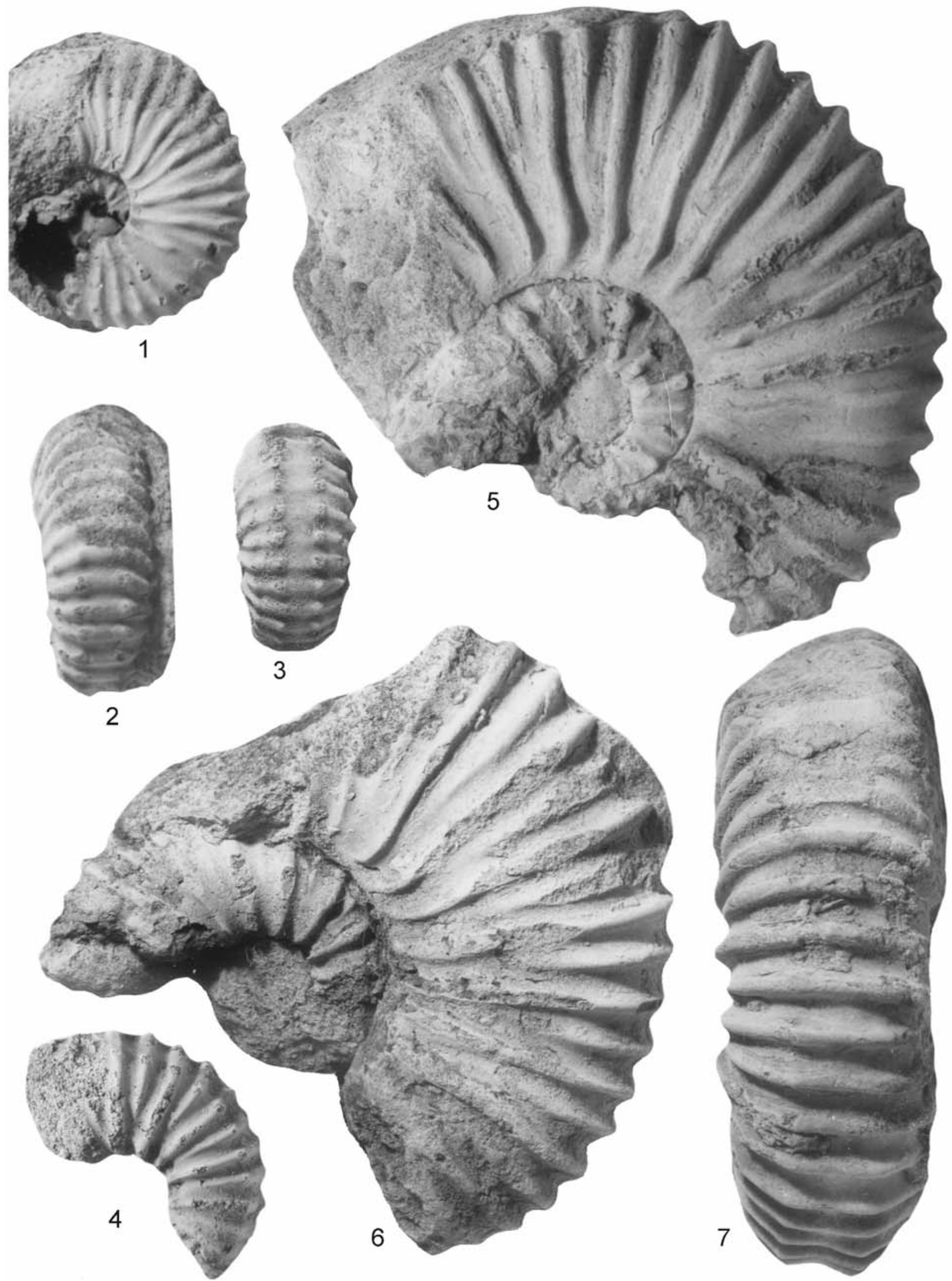


\section{PLATE 3}

Mantelliceras mantelli (J. Sowerby, 1814)

1-3 - UW1314; 4, 5 - UW1076, both from bed 11 of the Vohipaly section, Lower Cenomanian, Mantelliceras dixoni Zone.

All figures are $\times 1$ 

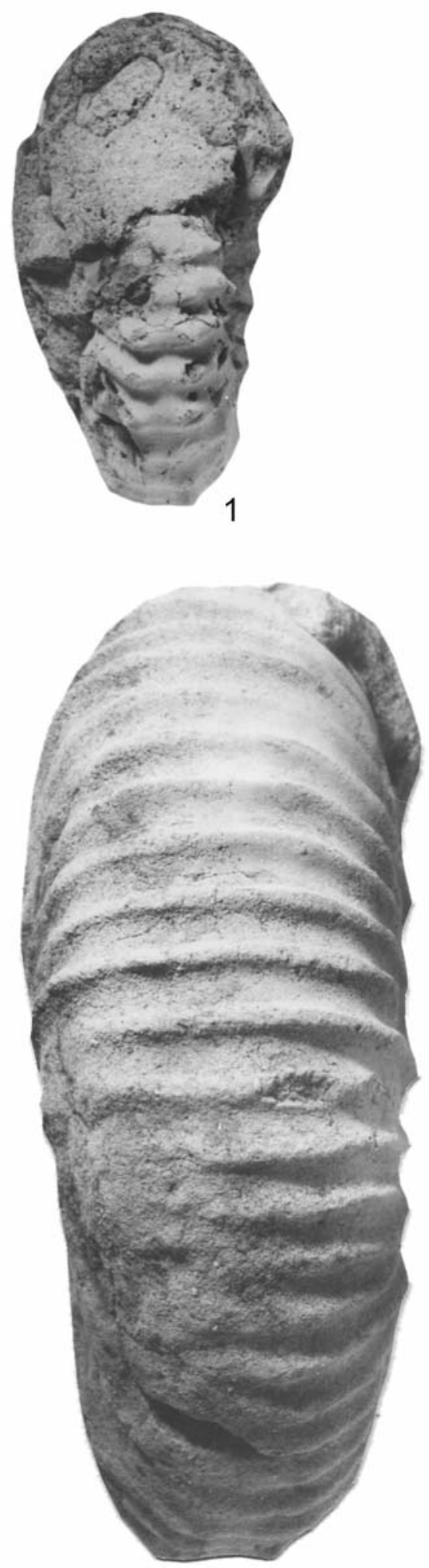

4
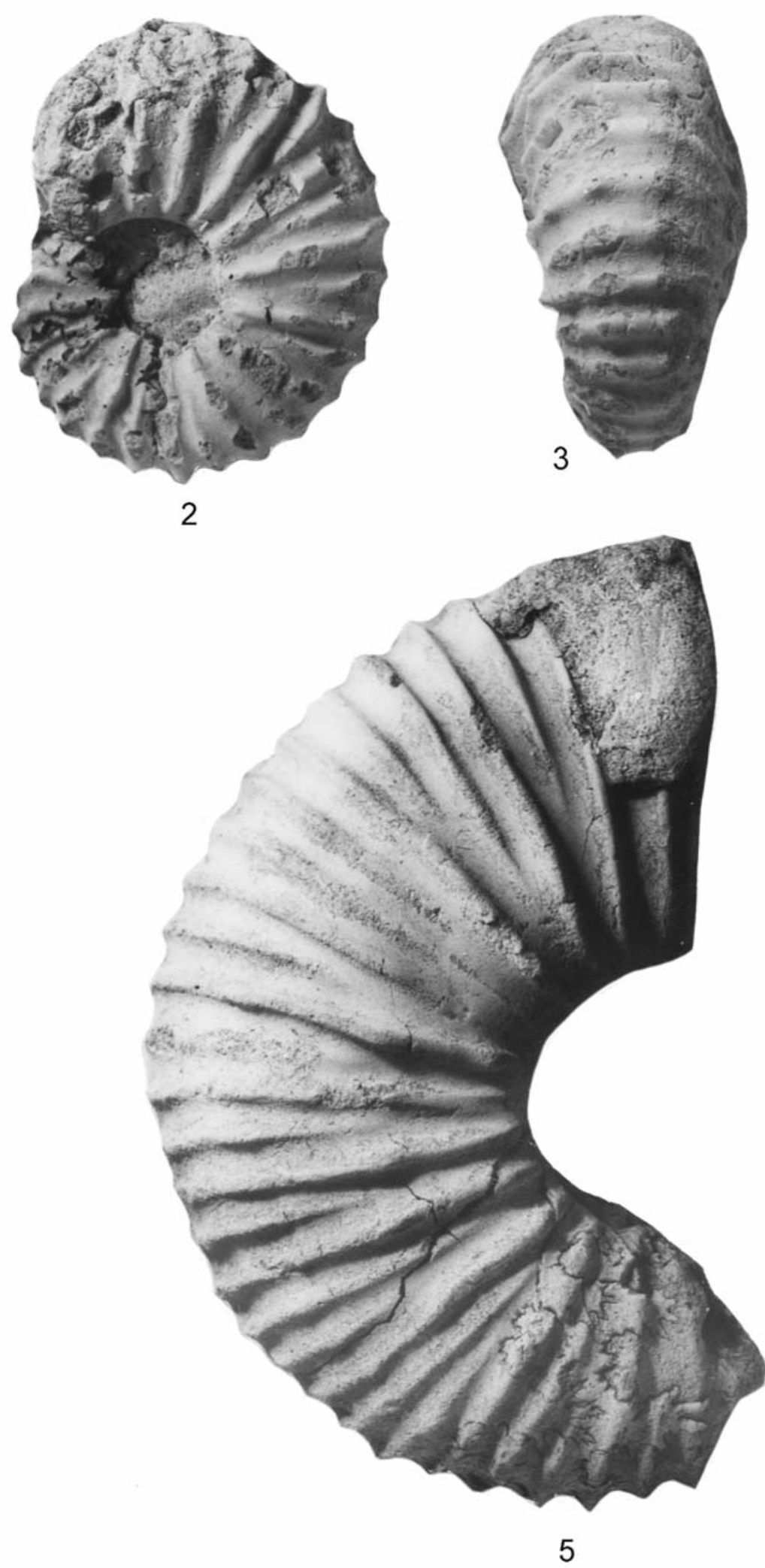


\section{PLATE 4}

1, 2 - Mantelliceras dixoni Spath, 1926b, UW1323; 3, 4-Mantelliceraas saxbii (Sharpe, 1857), UW1296; 5, 6, 7 - Mantelliceras picteti Hyatt, 1903, UW0813; 8, 9 - Sharpeiceras mocambiquense (Choffat, 1903).

The originals of figures $1-4$ are from bed $11 ; 5,6$, from beds 13-14; 7, from bed 14; 8, 9, from bed13 of the Vohipaly section, Lower Cenomanian, Mantelliceras dixoni Zone.

All figures are $\times 1$ 


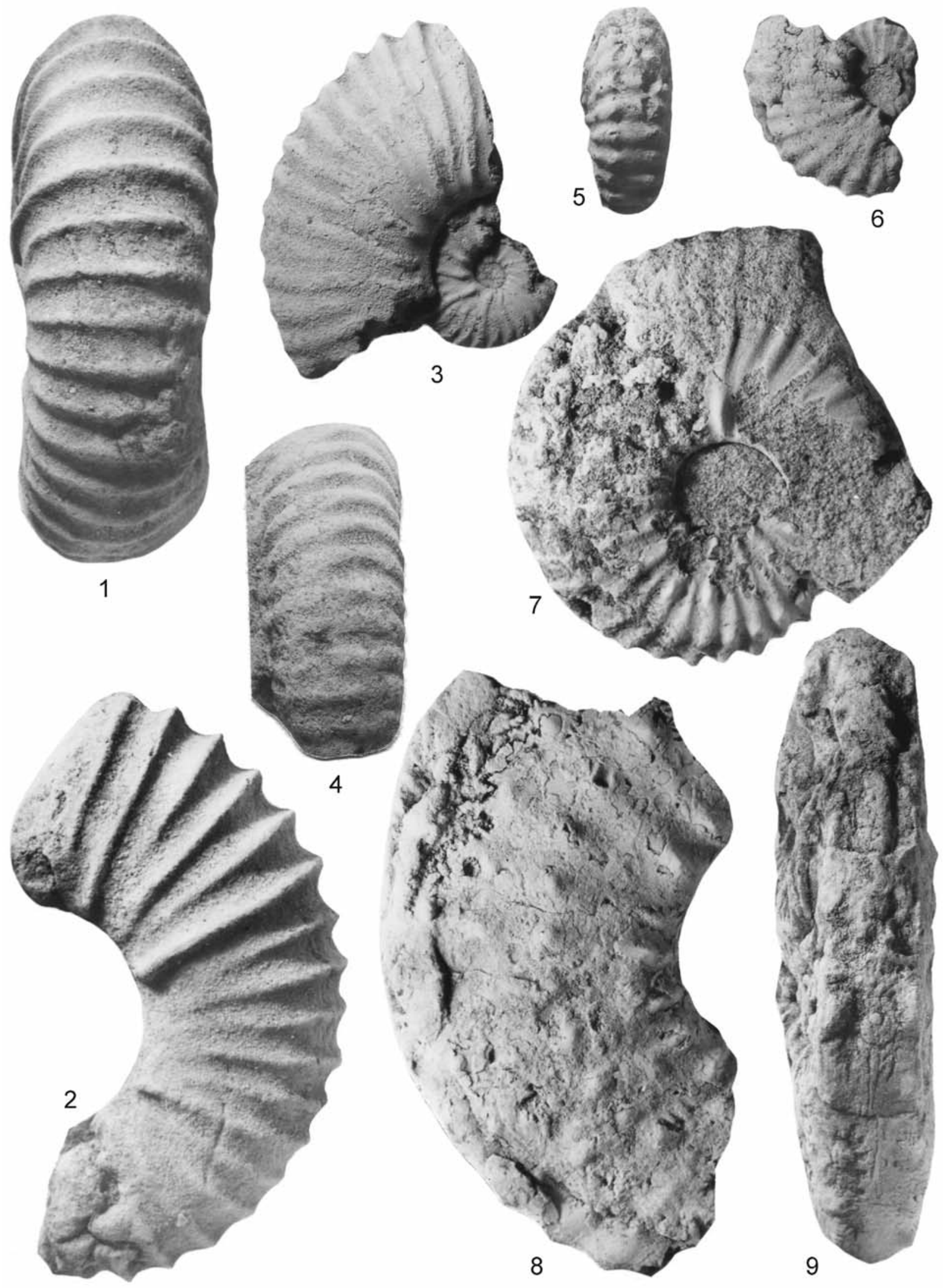




\section{PLATE 5}

1-3, 6-14 - Sharpeiceras falloti (Collignon, 1931). 1-3 - UW0844; 6, 7, 9, 10 UW0851; 11 - UW1544; 12, 13 - UW0861. 6 - the lectotype, the original of of Collignon, 1931, pl. 8 (4), fig. 10, from the Cenomanian east of Antsirane, Madagascar, in the collections of the Laboratoire de Paléontologie of the Université de Bourgogne, Dijon. 4, 5 -Mrhiliceras lapparenti (Pervinquière, 1907), UW 1515.

The originals of figures 1-3, 6-14, are from bed 21 of the Vohipaly section, Lower Cenomanian, Mantelliceras dixoni Zone. The original of figures 4, 5, is also from Vohipaly, and was collected loose.

Figures $1-7,9-14$ are $\times 1$; figure 8 is $\times 2$ 

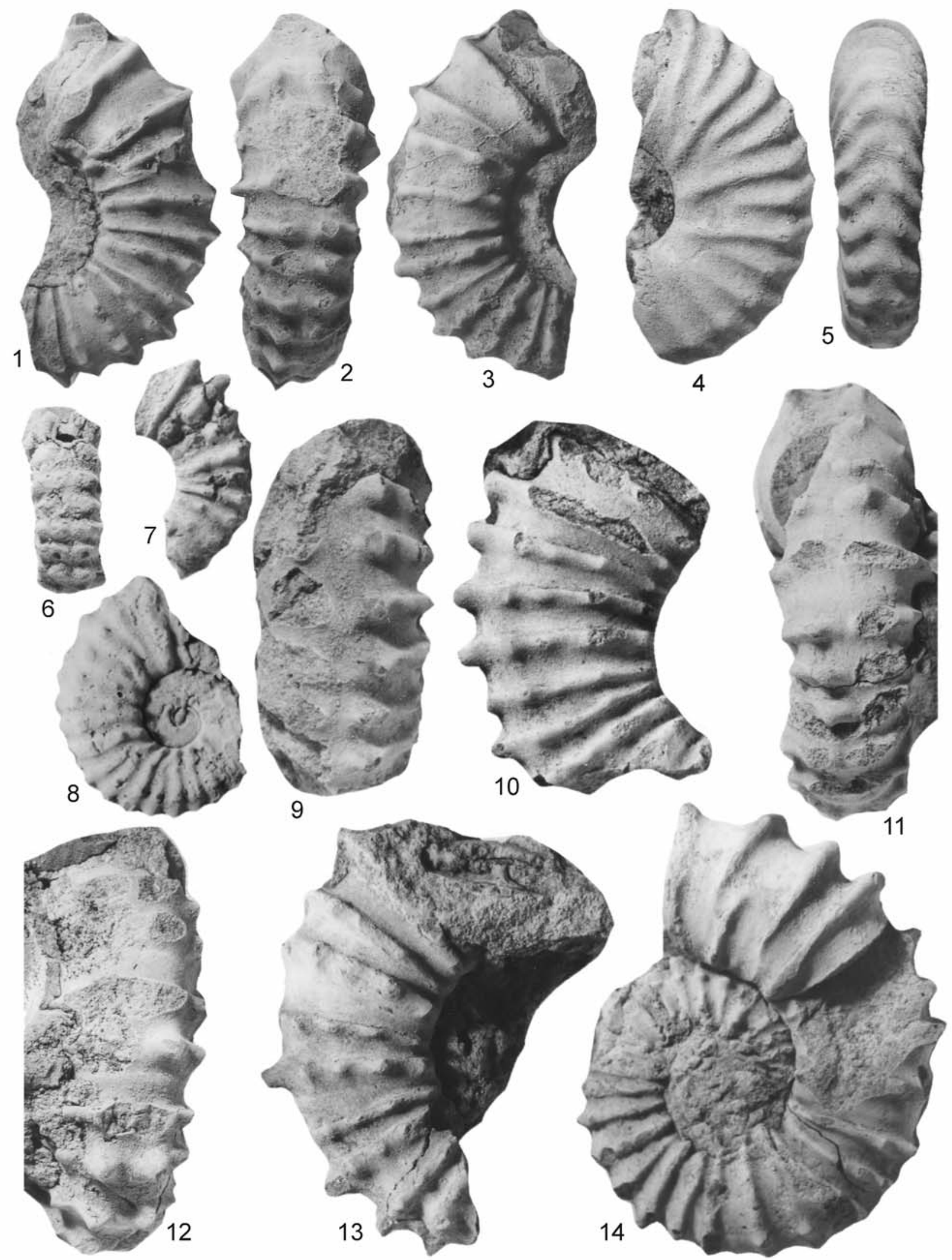


\section{PLATE 6}

1 - Sharpeiceras cf. florencae Spath, 1925, UW1259; 2 - Sharpeiceras mocambiquense (Choffat, 1903), UW1482.

The original of figure 1 is from bed 10; the original of figure 2 is from bed 11 of the Vohipaly section, Lower Cenomanian, Mantelliceras dixoni Zone.

Figures are $\times 1$ 

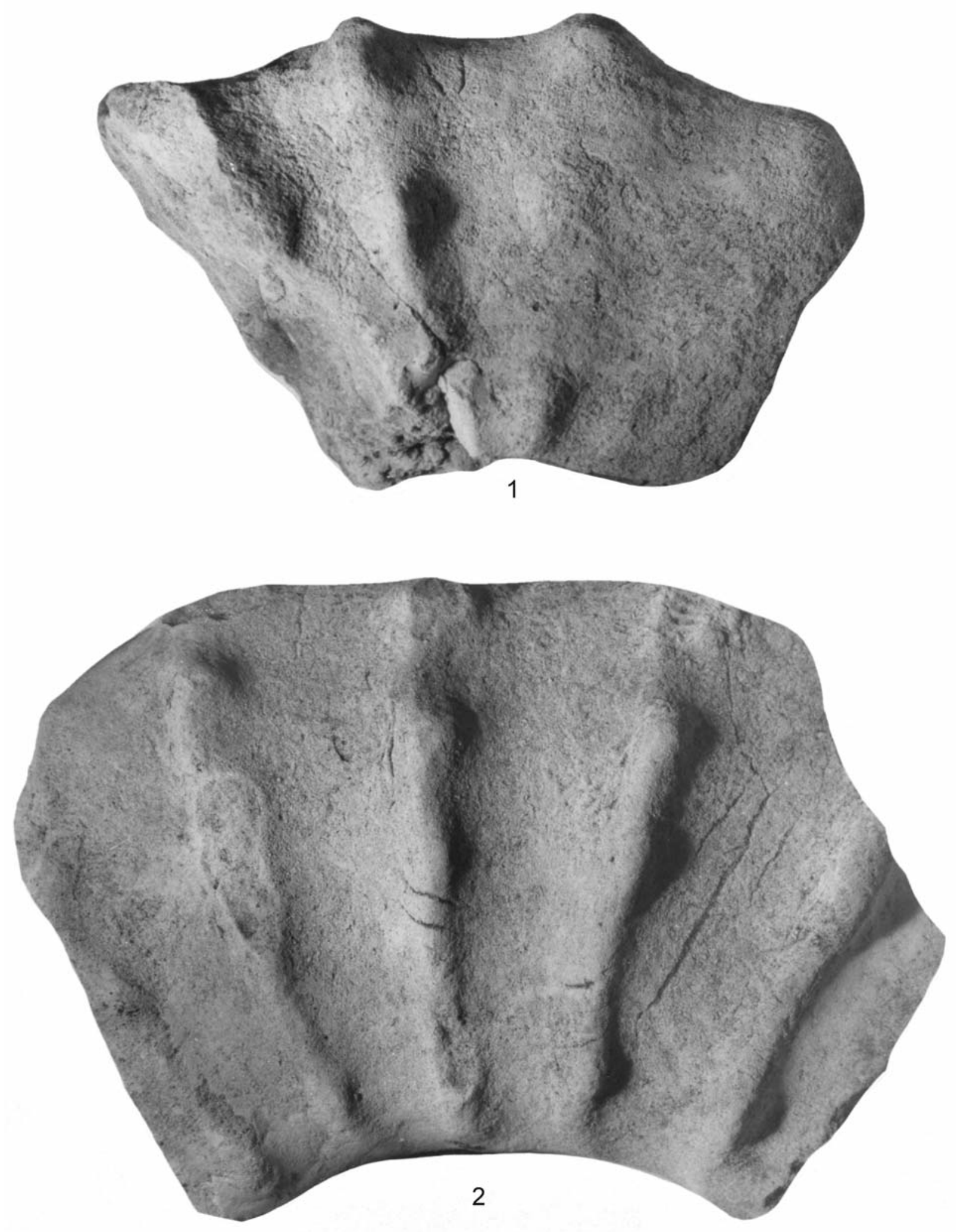


\section{PLATE 7}

1, 4-11 - Acompsoceras tenue Collignon 1964. 1 - UW0813; 4 - UW0840; 5, 6 -UW0864; 7 -UW0859; 8 -UW1252; 9, 10 -UW0835; 11 - UW1250. 3, 4 - Acanthoceras sp. juv., UW1948.

The original of figures 1, 4-11 are from bed 21 of the Vohipaly section, Lower Cenomanian, Mantelliceras dixoni Zone. The original of figures 2, 3, is from bed 3 of the Mahboboka section, Middle Cenomanian, Cunningtoniceras inerme Zone.

Figures 1, 4-11 are $\mathrm{x} 1$; figures 2, 3, are $\times 2$ 


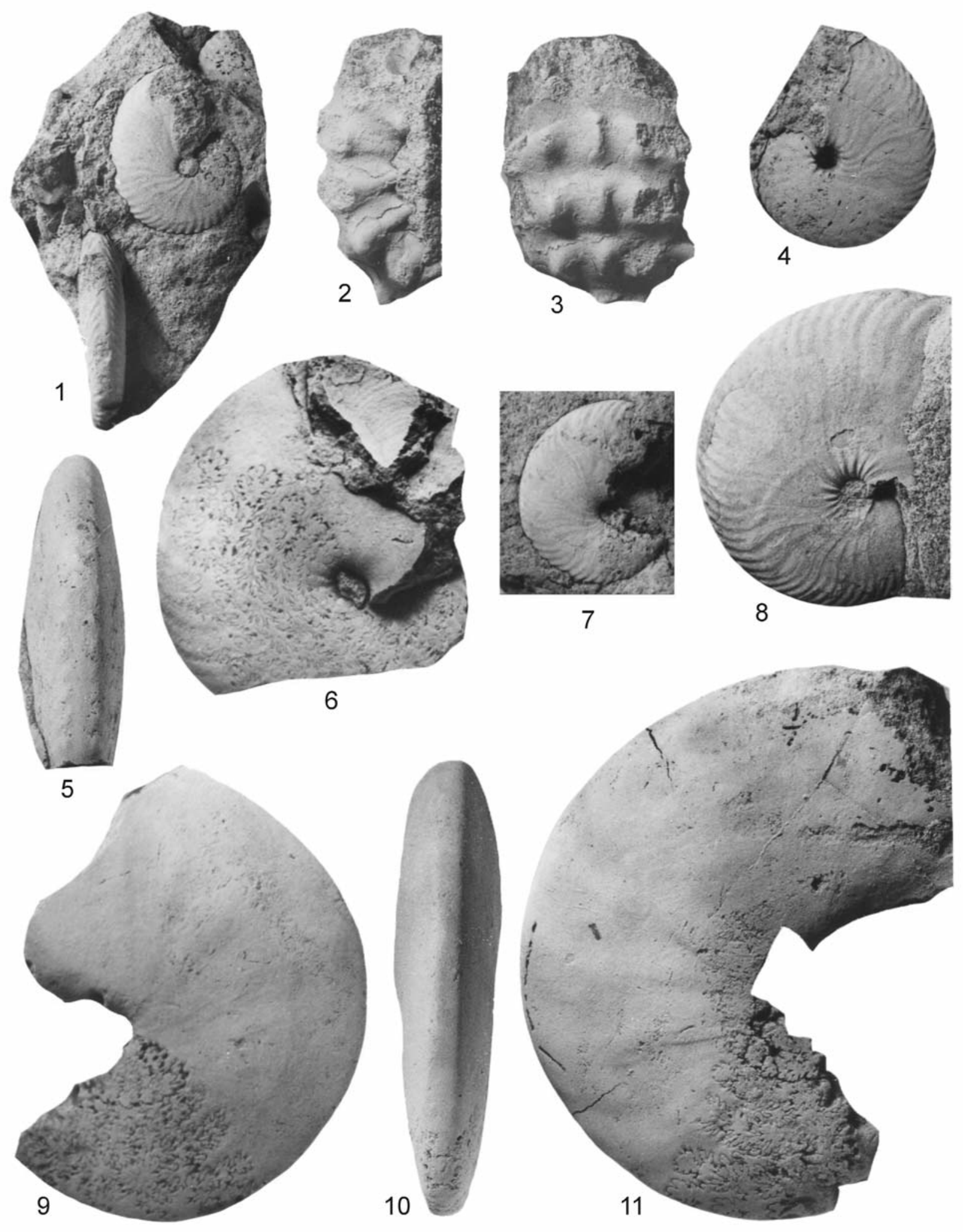




\section{PLATE 8}

1-6 - Cunningtoniceras cunningtoni (Sharpe, 1855). 1-4, UW1124, 5, 6, UW1962. 7, 8 - Acompsoceras renevieri (Sharpe, 1857), UW1523.

The originals of figures 1-4 are from bed 3 of the Mahaboboka section, Middle Cenomanian, Cunningtoniceras inerme Zone. The original of figures 7, 8, is from beds 1314 of the Vohipaly section, Lower Cenomanian, Mantelliceras dixoni Zone 

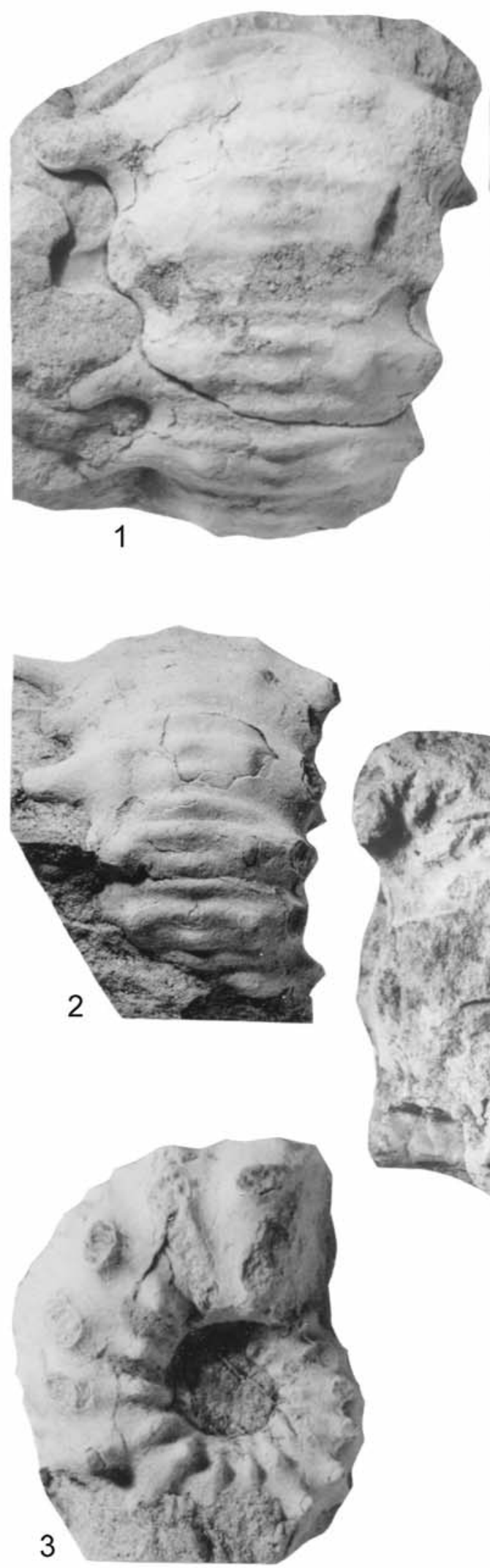
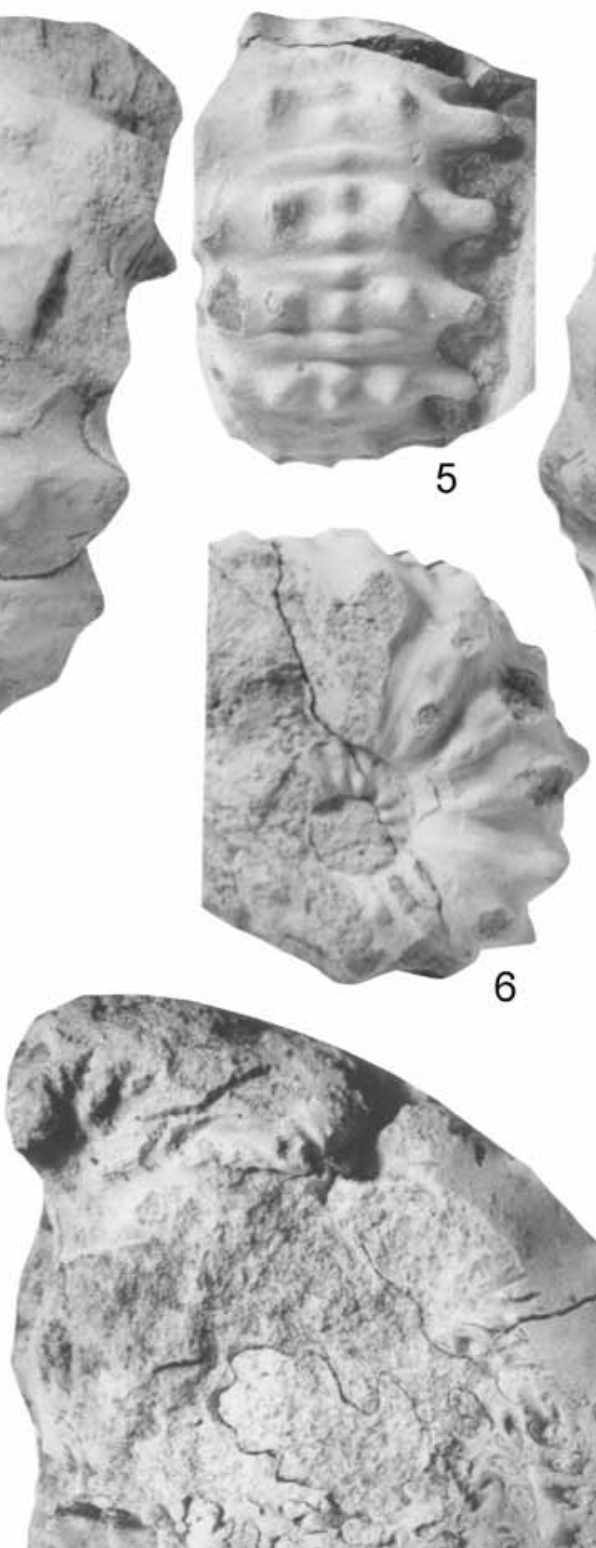

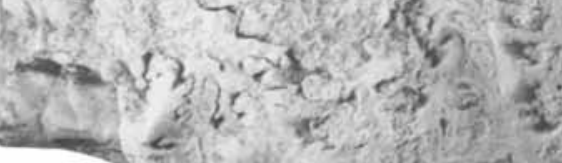
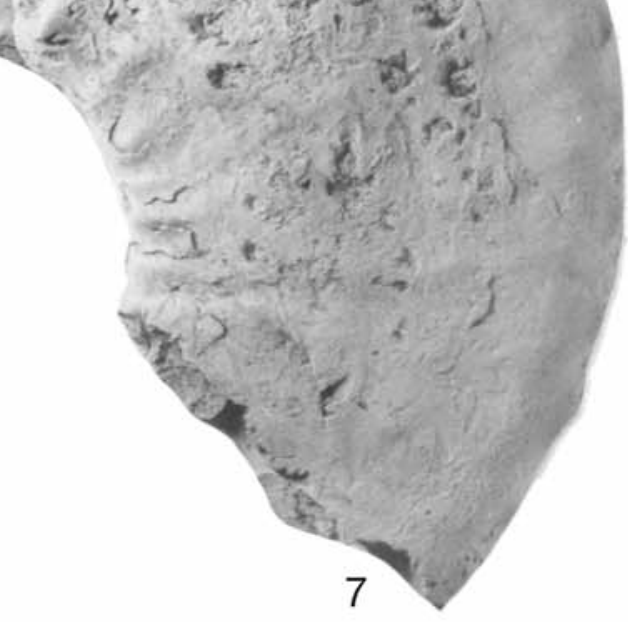


\section{PLATE 9}

1-3 - Turrilites scheuchzerianus Bosc, 1801. 1 - UW1366; 2 - UW1334; 3 - UW1311. 4-12 - Hypoturrilites taxyfabreae (Collignon, 1964); 4 - the holotype, the original of Collignon 1964, p. 50, pl. 330, fig. 1480, from Collignon's locality 474, Ouest de Beraketa sur Sakondry, housed in the collections of the Université de Bourgogne, Dijon; 5, 6 UW1964; 7, 8 - UW1320; 9 - UW1290; 10 - UW1267; 11 - UW1260; 12 - UW1063.

The originals of figures $1-3$ are from bed 23; 7-9, are from bed 11 of the Vohipaly section, Lower Cenomanian, Mantelliceras dixoni Zone. The original of figures 5, 6, is from bed 3 of the Mahaboboka section, Middle Cenomanian, Cunningtoniceras inerme Zone. The original of figures 10,11 are from Bereketa, the original of 12 is from Bereketa A, all Lower Cenomanian Mantelliceras dixoni Zone.

All figures are $\times 1$ 

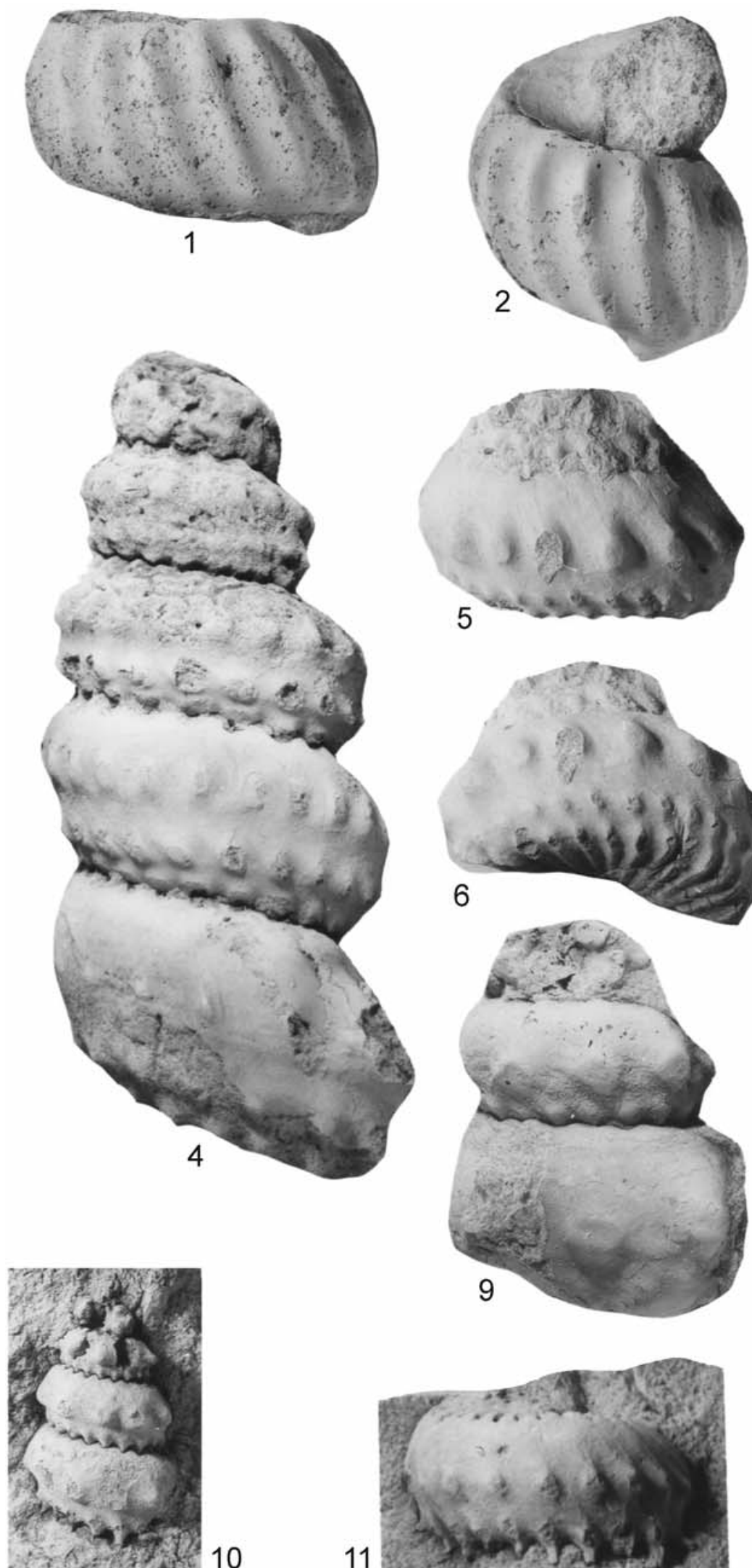
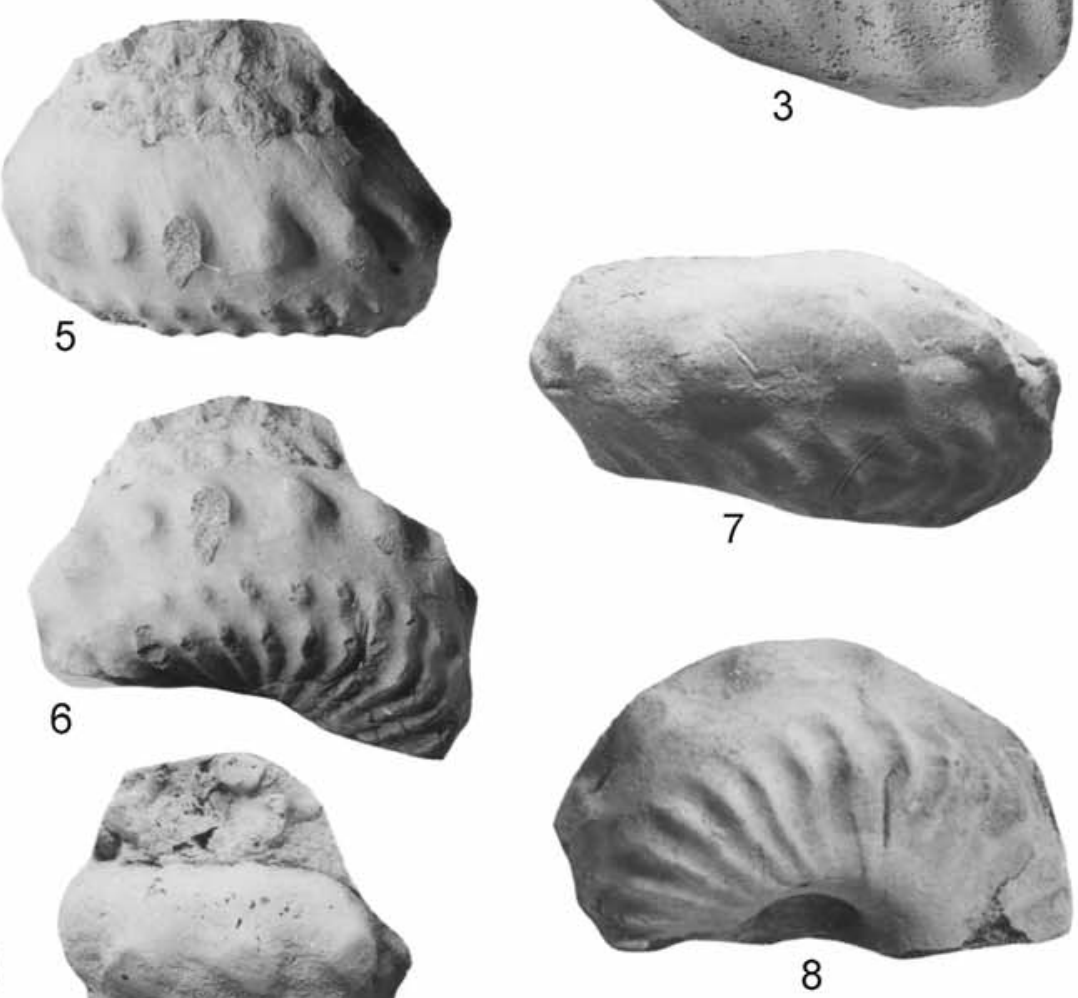

12

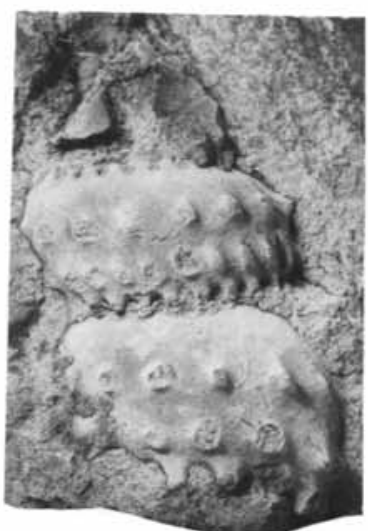




\section{Plate 10}

Sciponoceras antanimangaensis (Collignon, 1964)

1 - UW1522; 2, 3 - UW1991; 4 - UW0857; 5 - UW0843; 6, 7 - UW0863; 8, 9 UW1249. 10, 11 - the holotype, the original of Collignon 1964, p. 34, pl. 325, fig. 1451, from Collignon's locality 362, Signal Antanimanga 1 (Mandabe).

The originals of figures 1, 4-9 are from bed 21, the original of figures 2 and 3 are from bed 23 of the Vohipaly section, Lower Cenomanian, Mantelliceras dixoni Zone. 

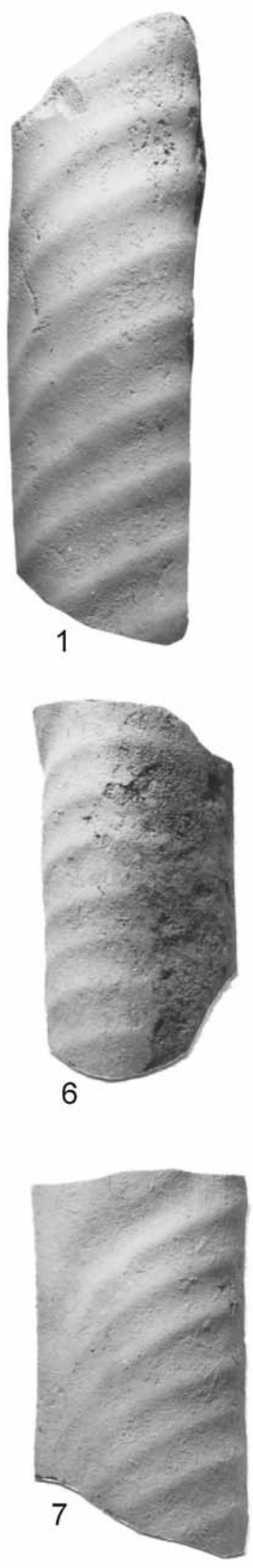
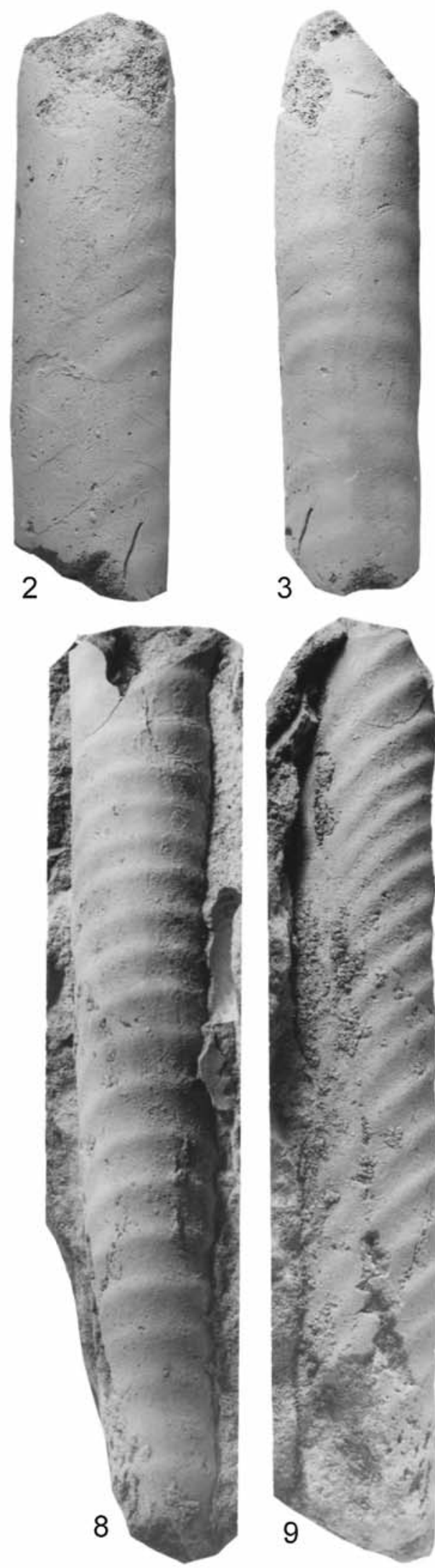
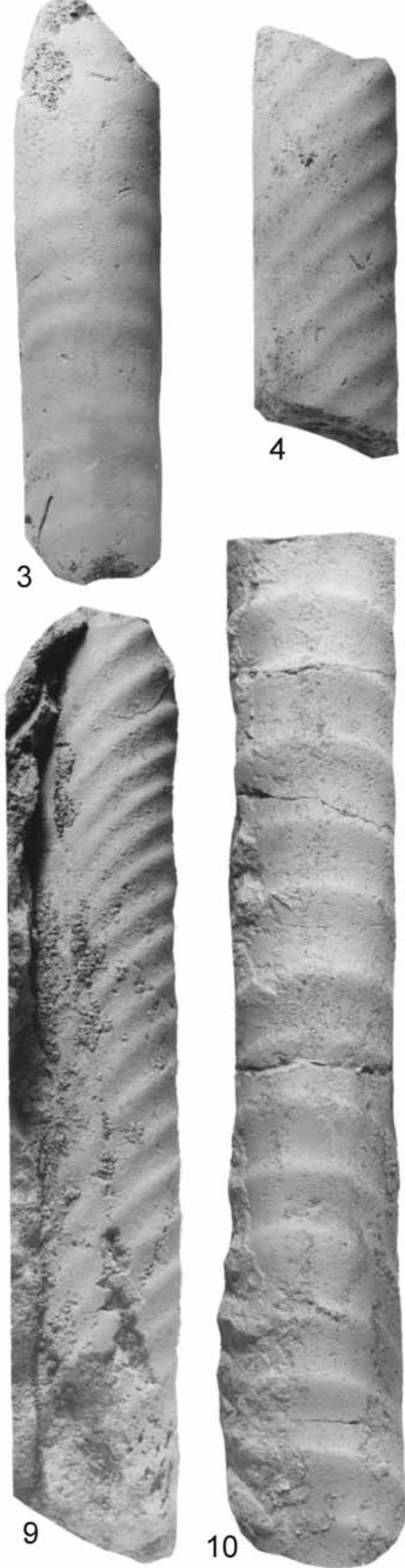
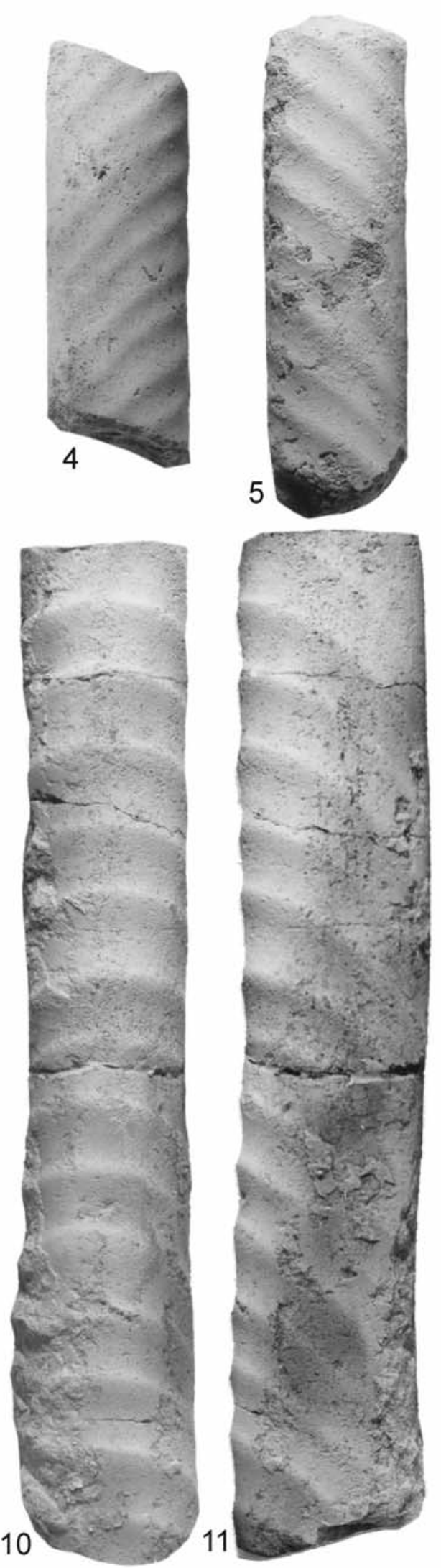